UNIVERSIDADE DE SÃO PAULO
FACULDADE DE CIEENCIAS FARMACÊUTICAS

CURSO DE PÓS-GRADUAÇÃO EM FARMÁCIA ÁREA DE ANÁLISES TÓXICOLOGICAS

\title{
IDENTIFICAÇÃO DE USUÁRIOS DE Cannabis POR CROMATOGRAFIA EM CAMADA DELGADA DE ALTA EFICIÊNCIA
}

Dissertação para obtenção do grau de MESTRE

Orientador:

Prof. Dr. Ovandir Alves Silva

São Paulo

1994 
Ficha Catalográfica

Elaborada pela Divisão de Biblioteca e Documentação do Conjunto das Químicas da USP.

S757i Identificação de usuários de Cannabis por cromatografia em camada delgada de alta eficiência / Eliani Spinelli.--São Paulo, 1994. $111 \mathrm{p}$.

Dissertação (mestrado) - Faculdade de Ciências Farmacêuticas da Universidade de São Paulo. Departamento de Análises Clínicas e Toxicológicas.

Orientador: Silva, Ovandir Alves

1. Cannabis: Análise: Toxicologia 2. Cromatografia em camada delgada de alta eficiência: Análise toxicológica I. T. II. Silva, Ovandir Alves, orientador 


\title{
ELIANI SPINELLI
}

\section{IDENTIFICAÇÃO DE USUÁRIOS DE Cannabis POR CROMATOGRAFIA EM CAMADA DELGADA DE ALTA EFICIÊNCIA}

\author{
COMISSÃO JULGADORA \\ DISSERTAÇÃO PARA OBTENÇÃO DO GRAU DE MESTRE
}

Prof. Dr. Ovandir Alves Silva

PRESIDENTE E ORIENTADOR

Prof. Dr. Daniel Romero Munoz

$2^{\circ}$ EXAMINADOR

Prof. Assoc. Luiz Marques de Sá

$3^{\circ}$ EXAMINADOR

São Paulo, 25 de novembro de 1994. 


\section{A DEUS}

pela presença constante e pela paternidade expressa na correção, no socorro e nas oportunidades abertas. 
A

minha família

pelo que cada um contribuiu com alegria, amor e enúncia. 
Ao Prof. Ovandir Alves Silva pela orientação sempre presente.

A Moema dos Santos pela normatização das referências bibliográficas.

A Prof.Maricê Nogueira de Oliveira e Auriluce Missiano de Oliveira pela assessoria técnica junto aos computadores

Ao Prof.Mário Polite pela revisão quanto aos aspectos teóricos da polarização da fluorescência

A Prof. Rosemary C.Pedroso pelo incentivo e pela ajuda na tradução dos textos em alemão.

A Cristina, Janaina e Andréa, colegas da pós-graduação, pela ajuda imprescindivel.

Ao Prof.Luiz Marques de Sá pela sugestão do tema deste trabalho 


\section{ERRATA}

1. Página 60 - não houve inclusão da amostra 9B na tabela 12, cujo resultado é: não detectado (ND). À amostra 10 corresponde o resultado positivo (+).

2. Página 64 - não houve inclusão da amostra 9B na tabela 15 , cujo resultado é negativo.

3. Página 71 - na tabela 20 , onde se lê canabinóides, leia-se $\mathrm{THCCOOH}$. 


\section{RESUMO}

A análise de fluidos biológicos para detecção de usuários de Cannabis não é rotina em nossos serviços de toxicologia forense pela falta de um método aplicável às condiçōes de trabalho desses laboratórios. Neste trabalho foi estudado um método que utiliza a cromatografia de camada delgada de alta eficiência (CCDAE) como técnica de identificação. Cinco mililitros de urina são submetidos à hidrólise alcalina e à extração líquido/líquido, com posterior aplicação do resíduo obtido na cromatoplaca. O limite de deteç̧ão em estudo realizado com adicionados foi de $5 \mathrm{ng} / \mathrm{ml}$. Urina de usuários de Cannabis quando submetidas a esta metodologia apresentaram resultado semelhante ao do padrão de $\mathrm{THCCOOH}$, principal produto de biotransformação do THC. As amostras utilizadas como branco de referência não apresentaram mancha semelhante. $\mathrm{Na}$ análise das amostras de usuários por imunoensaio de fluorescência polarizada ("cutoff" $50 \mathrm{ng} / \mathrm{ml}$ ) obteve-se resultado negativo para usuários moderados e ocasionais. Com auxilio de curva-padrão observou-se que a concentração provável de canabinóides nessas amostras estaria entre $20-50 \mathrm{ng} / \mathrm{ml}$. No estudo comparativo dos resultados obtidos nas duas técnicas, foi verificada uma correspondência de 100\% para as amostras de usuários com padrão de uso intenso. Nos usuários moderados e ocasionais não foi observada boa correspondência entre os resultados. 


\section{SUMÁRIO}

pág.

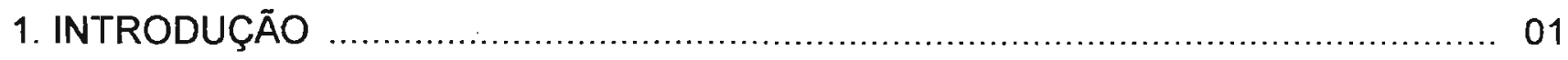

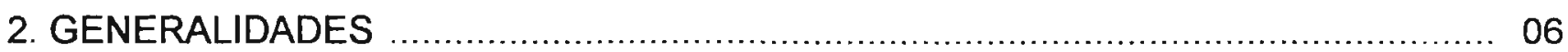

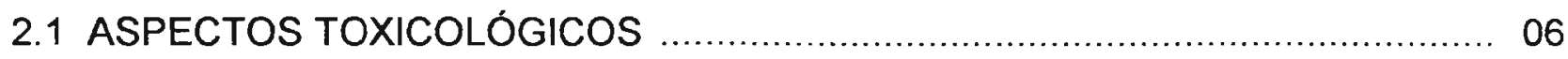

2.1.1 EFEITOS TÓXICOS A CURTO PRAZO ….............................................. 06

2.1.2 EFEITOS TÓXICOS A LONGO PRAZO …......................................... 09

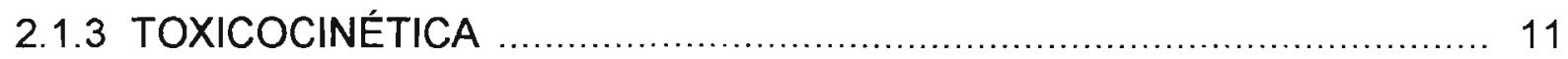

2.1.3.1 PERFIL PLASMÁTICO DO $\triangle^{9}$-THC E SEUS PRINCIPAIS PRODUTOS DE BIOTRANSFORMAÇÃO ……...................... 11

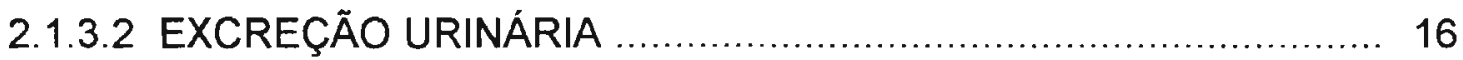

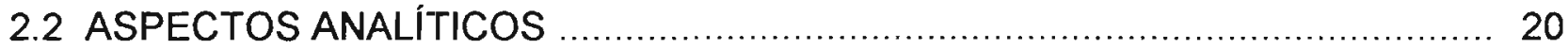

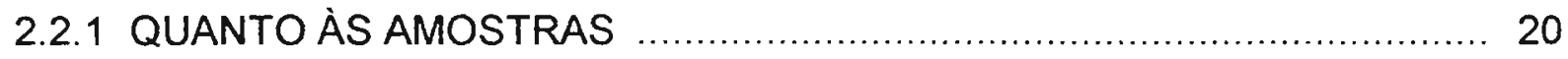

2.2.2 QUANTO À ESTABILIDADE DE CANABINÓIDES ............................. 21

2.2.3 QUANTO Ȧ SEPARAÇÃO E EXTRAÇÃO DO THCCOOH DA URINA ...... 23

2.2.4 IDENTIFICAÇÃO DO THCCOOH POR CROMATOGRAFIA EM CAMADA

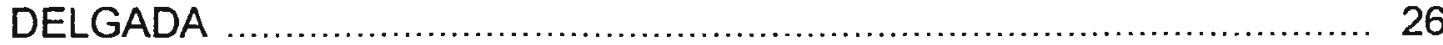

2.2.4.1 INFLUÊNCIA DA FASE ESTACIONÁRIA _.............................. 27

2.2.4.2 INFLUÊNCIA DA FASE MÓVEL …….................................... 28

2.2.4.3 ESTUDO DA DETECÇÃO DO THCCOOH ............................. 29

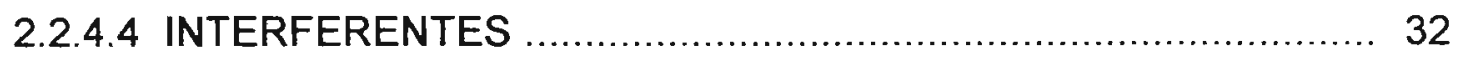

2.2.5 IDENTIFICAÇÃO POR TÉCNICAS IMUNOLÓGICAS ........................... 33

2.2.6 IMUNOENSAIO DE FLUORESCÊNCIA POLARIZADA ........................ 41

2.2.7 OUTRAS TÉCNICAS ANALÍTICAS UTILIZADAS NA ANÁLISE DE CANABINÓIDES EM FLUIDOS BIOLÓGICOS 


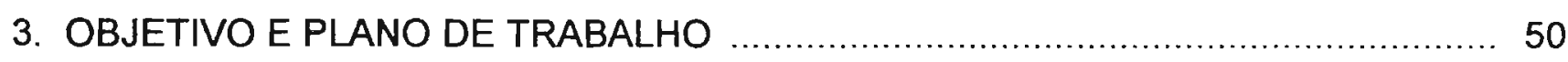

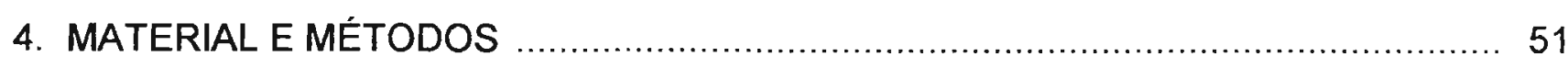

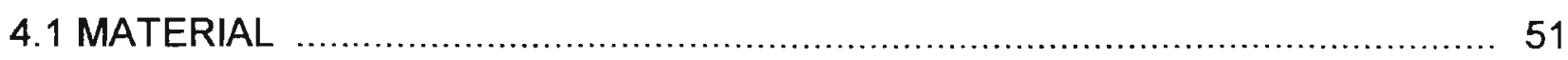

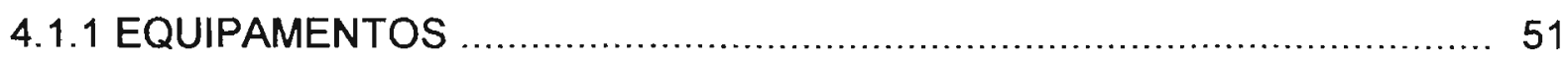

4.1.2 REAGENTES PARA IMUNOENSAIO ……......................................... 51

4.1.3 SOLVENTES, SOLUÇÕES E AGENTE CROMOGÊNICO ..................... 51

4.1.4 CROMATOPLACAS DE CROMATOGRAFIA EM CAMADA DELGADA DE DE ALTA EFICIÊNCIA ............................................................ 51

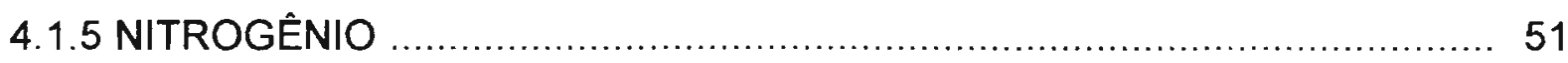

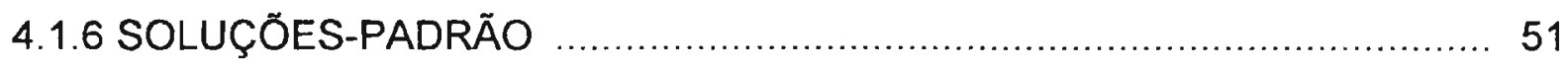

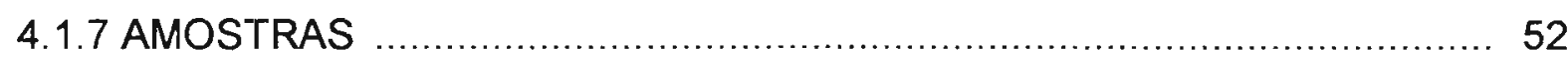

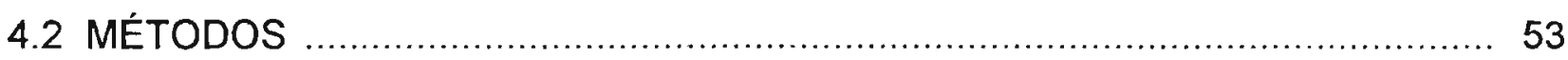

4.2.1 IDENTIFICAÇÃO POR CROMATOGRAFIA EM CAMADA DELGADA DE ALTA EFICIÊNCIA

4.2.1.1 DETERMINAÇÃO DO LIMITE DE DETECÇÃO DA TÉCNICA DE CROMATOGRAFIA EM CAMADA DELGADA DE ALTA EFICIÊNCIA PARA ANÁLISE DO THCCOOH

4.2.1.2 APLICAÇÃO DO MÉTODO DE MEATHERALL E GARRIOTT A ADICIONADOS DE THCCOOH

4.2.1.3 APLICAÇÃO DO MÉTODO DE MEATHERALL E GARRIOTT ÀS AMOSTRAS DE USUÁRIOS E "BRANCOS" DE REFERÊNCIA .... 54

4.2.1.4 APLICAÇÃO DO MÉTODO DE MEATHERALL E GARRIOTT MODIFICADO ÀS AMOSTRAS SELECIONADAS

4.2.2 IMUNOENSAIO DE FLUORESCÊNCIA POLARIZADA 56

4.2.2.1 APLICAÇÃO DO MÉTODO DE IMUNOENSAIO DE FLUORES-. CÉNCIA POLARIZADA ÀS AMOSTRAS SELECIONADAS 56 
4.2.2.2 CONSTRUÇÃO DA CURVA-PADRÃO PARA ESTUDO DO MÉTODO DE IMUNOENSAIO DE FLUORESCÊNCIA POLARIZADA NA DETECÇÃO DE THCCOOH

5. RESULTADOS

5.1 DETERMINAÇÃO DO LIMITE DE DETECÇÃO DA TÉCNICA DE CROMATOGRAFIA EM CAMADA DELGADA DE ALTA EFICIÉNCIA PARA ANÁLISE DE $\mathrm{THCCOOH}$

5.2 APLICAÇÃO DO MÉTODO DE MEATHERALL E GARRIOTT A ADICIONADOS DE THCCOOH

5.3 APLICAÇÃO DO MÉTODO DE MEATHERALL E GARRIOTT ÀS AMOSTRAS DE USUÁRIOS DE Cannabis

5.4 APLICAÇÃO DO MÉTODO DE MEATHERALL E GARRIOTT ÀS AMOSTRAS SELECIONADAS

5.5 APLICAÇÃO DO MÉTODO DE IMUNOENSAIO DE FLUORESCÉNCIA POLARIZADA ÀS AMOSTRAS DE USUÁRIOS DE Cannabis

5.6 ESTUDO DA TÉCNICA DE IMUNOENSAIO DE FLUORESCÊNCIA POLARIZADA: CONSTRUÇÃO DA CURVA-PADRÃO

6. DISCUSSÃO 


\section{INTRODUÇÃO}

Há mais de cinco mil anos que os efeitos psicoativos da Cannabis são conhecidos pelo homem ${ }^{142}$. Os últimos 20 anos, contudo, podem ser caracterizados como o período de maior interesse no seu estudo. Isto advém de várias razões que a colocaram no "status" de droga ilicíta mais consumida em todo o mundo25.

A maioria dos especialistas concorda que existem pelo menos três espécies de Cannabis, e as principais diferenças entre elas se relacionam às sementes, ao talo, ao hábito de crescimento e, em menor extensão, ao conteúdo resinoso ${ }^{128}$.

A espécie Cannabis sativa L., classificada por Linneaus em 1753, é encontrada em todo o continente americano. No Brasil, ela ocorre em diversas variedades cujo conteúdo em princípio ativo pode variar de 1 a $5 \% 142$.

A droga obtida a partir das espécies de Cannabis é conhecida no Brasil como maconha. Utilizada principalmente sob a forma de cigarros, ela é hoje a droga ilícita mais consumida em todo mundo, e este quadro parece não ser diferente no país $28,7,29,147$.

O problema do tráfico e consumo de drogas no Brasil vem-se avolumando em termos quantitativos e qualitativos. Nosso país se destaca como produtor de Cannabis, principalmente nas regiões Norte e Nordeste, especialmente para o consumo interno, e também tem sido utilizado como rota intermediária para o tráfico de outras drogas.

Segundo relatório fornecido pela Divisão de Repressão a Entorpecentes da Polícia Federal 14, entre 1989 e 1993 foram destruídos cerca de 17.655 .871 pés de Cannabis em plantações clandestinas localizadas por todo o país. Se um pé de Cannabis fornecer $100 \mathrm{~g}$ da droga pronta para consumo, então 1.765 toneladas de Cannabis não entraram no mercado. Acrescentado-se 59 toneladas de Cannabis pronta para consumo, apreendidas no mesmo período, disso resultaria uma quantidade suficiente para fabricar cerca de 1.823.319.660 cigarros de Cannabis ( $1 \mathrm{~g}$ por cigarro ).

Só neste ano de 1994, nos meses de janeiro a agosto, a quantidade total de Cannabis apreendida seria suficiente para fabricar 142.000 .000 de cigarros de Cannabis. Em oito meses, isto provavelmente supriria o consumo de milhöes de usuários de fins-de-semana.

Mesmo sabendo que toda a Cannabis produzida no Brasil é para consumo interno, não se pode predizer que parcela da droga circulante está sendo realmente apreendida. Além disso, a região Sul e parte da região Sudeste ainda recebem reforço do tráfico internacional. 
Até hoje, pouco se conhece da magnitude do problema do abuso de drogas psicotrópicas no País 20. A maioria dos dados estatísticos oficiais são restritos a algumas comunidades, oriundos de trabalhos isolados que enfocam, principalmente, 0 meio estudantil, não sendo prudente extrapolar esses dados, tendo em vista as dimensões e características de nosso país.

COTRIM e cols ${ }^{28}$ relatam que as internações devidas à dependência de drogas (excluindo-se o álcool), apesar de serem alvo de notificação obrigatória ao Ministério da Saúde, não são informadas por cerca de $45 \%$ das clínicas e hospitais; e as que notificam o fazem de modo incompleto.

ALMEIDA e cols 4 , CARLINI e COTRIM ${ }^{27}$ relatam que, na maioria das pesquisas realizadas entre estudantes, a Cannabis aparece como a droga ilícita mais consumida.

Alguns trabalhos mostram que 0 inicio do uso da Cannabis acontece nos primeiros anos da adolescência124,148. SMITH e cols ${ }^{127}$, estudando um grupo de adolescentes usuários de Cannabis, observou que os picos de consumo se localizavam imediatamente antes de entrar na escola (6h), logo após as aulas (12h) e à noite $(18 \mathrm{~h} / 20 \mathrm{~h})$.

O uso de álcool e drogas, associado à evasão escolar, tem um impacto social tremendo na incidência de marginalidade, e novamente, a Cannabis se sobressai por seu alto consumo 91

CARLSON e EDWARDS 18 realizaram estudo relacionando valores humanos com uso de Cannabis. Os autores observaram que alguns valores enfatizados no grupo de não-usuários, como o autocontrole, a responsabilidade e a prudência, não o eram no grupo de usuários. Estes priorizavam outros valores, como prazer, criatividade e vida excitante.

Um estudo realizado em escolas mostrou que os usuários de drogas estão mais sujeitos à violência, tanto como agressores quanto como vítimas ${ }^{88}$. Trabalho realizado em uma casa de detenção para menores infratores mostrou que a frequência do uso de Cannabis se relaciona bem com relatos de abuso físico, sexual e distúrbios emocionais ${ }^{32}$. A busca desenfreada de recursos para aquisição de drogas faz os índices de criminalidade contra o patrimônio subirem a niveis preocupantes ${ }^{147}$

Muitos acidentes fatais de trânsito matam milhares de pessoas por ano em todo - mundo. A relação do uso de Cannabis com acidentes de trânsito tem sido demonstrada em alguns trabalhos, com índices de $6-20 \%$ de resultados positivos. Sua participação em homicídios pode alcançar a casa dos $34 \% 50,65,52$.

Em todas essas pesquisas é difícil estabelecer o papel isolado da Cannabis, já que esta é quase sempre encontrada em associação com o álcool. A alta incidência 
dessa interação, observada na maioria dos levantamentos, quer em escolas , penitenciárias ou na investigação de acidentes de trânsito e homicídios, se constitui em um alerta para os que defendem a sua liberação. O sinergismo entre o álcool e a Cannabis já foi comprovado em vários efeitos farmacológicos, inclusive na queda do desempenho quanto à condução de veículos $60,66,21$

A inovação mais importante da atual Lei Antitóxicos (Lei n.6368/76) constitui-se no tratamento diferenciado que se deu ao traficante e ao usuário. A este último, estabelece a lei que seja encaminhado a tratamento, respondendo ao processo judicial em liberdade; mais ainda: em seu artigo terceiro, a Lei avança na criação de um Sistema Nacional de Prevenção, Fiscalização e Repressão, e estabelece, em seu artigo primeiro, que é dever de toda pessoa física ou jurídica colaborar na execução de medidas preventivas e repressivas ${ }^{132}$.

Muitos setores governamentais ligados à Segurança Pública têm manifestado interesse na instalação de programas de detecção e reabilitação de dependentes de álcool e outras drogas.

Com o advento de uma nova mentalidade na área trabalhista, voltada para as questões inerentes à saúde do trabalhador e à segurança no ambiente de trabalho, um número cada vez maior de empresas realiza a implantação de programas para detecção e recuperação de usuários de álcool e outras drogas de abuso ${ }^{138,75}$. Sabe-se que cerca de $25 \%$ das empresas norte-americanas possuem esses programas já instalados ${ }^{138}$. A contribuição social desses programas é maior quanto mais cedo se detectar o usuário, a fim de que, pela ação preventiva, se evite a instalação de um quadro de dependência química cujo índice de recuperação pode ser muito baixo, menor que $40 \% 51$.

As clínicas de reabilitação de dependentes químicos também solicitam exames toxicológicos para detecção de drogas de abuso, como meio de avaliar a confiabilidade do relato do paciente em tratamento 47,122 .

Cresce, cada vez mais, a demanda para testes de drogas como fruto de pressões sociais para barrar a expansão do abuso de substâncias químicas e prover maior proteção aos seus membros ${ }^{19}$.

O desenvolvimento de metodologias analíticas cresceu muito nos últimos anos, pressionado pela necessidade de análise simultânea de um grande número de amostras, com requerimentos de especificidade $\theta$ sensibilidade adequadas. Esse desenvolvimento se faz sentir com o advento de novas técnicas automatizadas de análise.

A detecção do $\Delta^{9}$-tetrahydrocannabinol (THC), principal constituinte ativo da Cannabis, feita primordialmente no sangue, é prova inequivoca do uso dessa droga. 
Entretranto, o decaimento rápido dos níveis plasmáticos a concentrações extremamente baixas conduz, invariavelmente, a resultados negativos se for ultrapassado o período de deteç̧ão, e se a técnica analítica empregada não for suficientemente sensivel'131.

Em relação à amostra, a urina também pode ser utilizada para caracterizar o uso de Cannabis. A detecção na urina do principal produto de biotransformação do THC, O 11-nor-9-carboxi- $\Delta^{9}-$ THC ( THCCOOH ), também se constitui em evidência conclusiva de uso da Cannabis ${ }^{78}$

$\mathrm{Na}$ área forense, no que se refere à detenção de indivíduos suspeitos, um resultado positivo no exame de urina pode ser utilizado para comprovar o uso ilícito. Outras respostas, porém, não podem ser obtidas, como, por exemplo, saber se 0 indivíduo estava ou não sob efeito farmacológico em um determinado momento, ou mesmo dizer em torno de que hora a droga teria sido utilizada ${ }^{102,50}$.

Normalmente, a análise toxicológica da urina para deteç̧ão de fármacos de abuso compreende duas fases: triagem e confirmação. A fase de triagem visa separar as amostras em positivas e negativas, sendo que as positivas requerem posterior confirmação por técnica mais sofisticada. Os ensaios imunológicos têm sido largamente empregados na fase de triagem, todavia, nós ainda dependemos da importação de equipamentos e de reagentes, o que encarece a análise e dificulta sua implantação principalmente no setor público.

Como no Brasil o uso de Cannabis é proibido, a aplicação de sanções penais exige a caracterização de usuários a partir da análise toxicológica forense.

Essas consideraçōes nos conduziram ao estudo de um método que fosse acessivel, de baixo custo e confiável para suprir essa demanda crescente na área analítica, dentro das condições disponiveis nos laboratórios de toxicologia do país.

Entre as técnicas normalmente recomendadas, a cromatografia em camada delgada (CCD) se sobressai pela sua simplicidade, praticidade, baixo custo e relativa especificidade, além de permitir a análise simultânea de várias amostras, sem necessitar de aparelhos sofisticados 77,78 .

A CCD é ainda a técrica mais empregada em todos os Institutos de Medicina Legal do nosso país; mas, por não possuir sensibilidade suficiente, a detecção de usuários de Cannabis só era possível quando utilizados grandes volumes de amostra, que na maioria das vezes não está disponível.

A introdução da cromatografia em camada delgada de alta eficiência (CCDAE) permitiu contornar esse problema, pois requer a utilização de pequenos volumes de amostra e possui sensibilidade suficiente para ser empregada nesse tipo de análise. 
Por serem poucas as informações disponiveis na literatura sobre o seu emprego na detecção de usuários de Cannabis, necessário se fazia estudar uma metodologia em CCDAE aplicável às condições de trabalho existentes no Brasil.

$O$ imunoensaio de fluorescência polarizada (FPIA), terminologia que se adotou neste trabalho, vem tendo grande aceitação por parte de muitos laboratórios. Por ser técnica ainda pouco conhecida em nosso país, era necessário estudá-la em seus aspectos teórico-práticos, para estabelecer os critérios necessários à boa interpretação dos resultados.

Neste estudo, o FPIA foi escolhido para formar o par analítico complementar à técnica cromatográfica estudada, tendo em vista um axioma em toxicologia que diz: "duas técnicas com princípios analíticos diferentes precisam ser empregadas para identificar a presença de um composto"47.

A possibilidade de detectar usuários de Cannabis através da CCDAE representa um avanço metodológico importante para a análise toxicológica. Em nosso país, 0 método estudado neste trabalho possibilita que a detecção de usuários de Cannabis seja definitivamente introduzida na rotina analítica dos laboratórios de toxicologia forense. 


\section{GENERALIDADES}

Aspectos botânicos e farmacognósicos, bem como estudos relativos à toxicodinamia e toxicocinética da Cannabis, foram anteriormente abordados por outros autores ${ }^{118,120}$.Devido ao caráter do presente trabalho, contudo, é importante levantar alguns aspectos de interesse, principalmente médico-legal, com os quais os toxicologistas são diariamente confrontados.

\subsection{Aspectos Toxicológicos}

\subsubsection{Efeitos tóxicos a curto prazo}

O $\Delta^{9}-\mathrm{THC}$, principal constituinte psicoativo da Cannabis, exerce seus efeitos proeminentes no organismo humano primeiramente no sistema cardiovascular (SCV), seguido por alterações no sistema nervoso central (SNC), cujo mecanismo ainda não está totalmente elucidado.

Segundo as revisões realizadas por JAFFE ${ }^{66}$, CHIANG $^{21}$,JONES ${ }^{75}$,HOLLISTER 60 e DEWEY ${ }^{34}$, os principais efeitos referentes à intoxicação aguda no organismo humano devido ao uso de Cannabis se encontram resumidos nas tabelas 1 e 2.

Segundo WEINTRAUB ${ }^{142}$, é comum entre os usuários considerar que a dose de 5 $\mathrm{mg}$ produz um efeito médio, de curta duração, e que doses maiores que $15 \mathrm{mg}$ produzem efeito intenso e mais prolongado.

STAFFORD ${ }^{128}$ relata que fumar um cigarro contendo $6 \mathrm{mg}$, ou introduzir por via oral $15 \mathrm{mg}$ de THC produz um efeito psicoativo leve na maioria dos usuários; e que fumar um cigarro contendo $30 \mathrm{mg}$, ou introduzir por via oral $75 \mathrm{mg}$ de THC tende a produzir efeitos muito intensos, comparáveis com os obtidos por LSD.

Os cigarros de Cannabis encontrados no Brasil variam de peso entre $250-$ $1000 \mathrm{mg}$. Seu conteúdo em THC também é variável, entre 0,5-5\%142. Convém lembrar que o aproveitamento máximo de um cigarro para um fumante experiente conduz à absorção de quantidades inferiores a $30 \%$ do seu conteúdo em THC ${ }^{128}$.

Outro fato importante é que o padrão de uso mais comum consiste na utilização de doses repetidas ("tragadas"). Em geral, uma vez atingido o efeito desejado, o dependente pára de fumar, só retornando quando o efeito tiver cessado ${ }^{120}$. 
Tabela 1. Efeitos farmacológicos da Cannabis no sistema cardiovascular.

\section{EM DOSES USUAIS *}

- Taquicardia

- Vasodilatação conjuntival .

- Vasoconstriç̧ão periférica. Efeitos: pés e mãos frios; boca e garganta secas; diminuição do lacrimejamento; diminuição da sudorese; hipo ou hipertermia: aumento ou diminuição do apetite

- Pressão sanguínea aumentada na posição supina, levemente diminuída ou inalterada em outras posições

\section{EM DOSES ELEVADAS **}

- Taquicardia intensificada

- Vasodilatação conjuntival

- Efeitos devidos à vasoconstrição periférica intensificados

$$
\begin{aligned}
& \text { Obs.: via de exposição : pulmonar } \\
& \text { início do efeito : } 9 \text { a } 28 \mathrm{~min} \\
& \text { duração do efeito : } 39 \text { a } 120 \mathrm{~min} \\
& \text { * : } \\
& 5 \text { - } 6 \mathrm{mg} \text { de } \Delta^{9}-\mathrm{THC}^{142,128} \\
& \star * \\
& 15 \text { - } 30 \mathrm{mg} \text { de } \Delta^{9}-\mathrm{THC}^{142,128}
\end{aligned}
$$

- Hipotensão ortostática 
Tabela 2. Efeitos farmacológicos da Cannabis no sistema nervoso central.

\begin{tabular}{|c|c|}
\hline EM DOSES USUAIS * & EM DOSES ELEVADAS ** \\
\hline $\begin{array}{l}\text { - Periodo inicial de euforia (high), } \\
\text { seguido por sonolência e relaxa- } \\
\text { mento quando o individuo está } \\
\text { sozinho; em grupo, esse efeito é } \\
\text { menos pronunciado, podendo o } \\
\text { individuo tomar-se falante. }\end{array}$ & $\begin{array}{l}\text { - Euforia pode chegar a ser substi- } \\
\text { tuída por uma sensação de } \\
\text { pâni- } \\
\text { co causada pelo aumento da } \\
\text { ansiedade e sentimentos de que } \\
\text { o efeito não vai acabar nunca. }\end{array}$ \\
\hline $\begin{array}{l}\text { - Desintegração temporal: noção de } \\
\text { tempo alterada; tendência de con- } \\
\text { fundir passado, presente e futuro. }\end{array}$ & $\begin{array}{l}\text { - Desintegração temporal } \\
\text { acentuada. }\end{array}$ \\
\hline $\begin{array}{l}\text { - Despersonalização com sentimento } \\
\text { de irrealidade sobre si mesmo. com } \\
\text { perda da introspecção; sentimentos } \\
\text { paranóicos. }\end{array}$ & $\begin{array}{l}\text { - Acentuação da despersonaliza- } \\
\text { ção. }\end{array}$ \\
\hline $\begin{array}{l}\text { - Dificuldade na concentração, com } \\
\text { prejuízo na memória recente; dimi- } \\
\text { nuição da clareza no diálogo. }\end{array}$ & $\begin{array}{l}\text { - Pensamento confuso e desorgani- } \\
\text { zado. }\end{array}$ \\
\hline $\begin{array}{l}\text { - Maior importância a outros sentidos } \\
\text { como tato, gosto e odor. Visão agu- } \\
\text { çada com distorções visuais. }\end{array}$ & $\begin{array}{l}\text { - Mesmas alterações nos sentidos } \\
\text { observadas nas doses usuais. }\end{array}$ \\
\hline $\begin{array}{l}\text { - Diminuição no desempenho de } \\
\text { tarefas mais complexas que incluem } \\
\text { percepção, atenção e processamen- } \\
\text { to de informação. }\end{array}$ & $\begin{array}{l}\text { - Diminuição do desempenho na } \\
\text { realização de tarefas motoras } \\
\text { simples. } \\
\text { - Estado de intoxicação mais } \\
\text { intenso e mais prolongado, } \\
\text { podendo ocasionar urgências } \\
\text { psiquiátricas. }\end{array}$ \\
\hline
\end{tabular}

\begin{tabular}{|c|c|c|}
\hline Obs: & $\begin{array}{l}\text { Via de exposição: } \\
\text { Inicio do efeito: } \\
\text { Duração do efeito: }\end{array}$ & $\begin{array}{l}\text { pulmonar } \\
10 \text { a } 45 \text { minutos } \\
2 \text { a } 4 \text { horas para o efeito psicológico, que é } \\
\text { perceptivel para o usuário; } 4 \text { a } 8 \text { horas para a } \\
\text { queda no desempenho, não sendo perceptível } \\
\text { para o usuário } 66 \text {. }\end{array}$ \\
\hline & * : & $5-6 \mathrm{mg}$ de $\Delta^{9}-\mathrm{THC} 142,128$ \\
\hline & ** : & $15-30 \mathrm{mg}$ de $\Delta^{9}-\mathrm{THC} \quad 142,128$ \\
\hline
\end{tabular}


Não há relato, na literatura, de morte causada exclusivamente por Cannabis, nem mesmo em acidentes com indivíduos que carregam pequenos pacotes com resina ou óleo de haxixe dentro do próprio corpo ("bodypacker").

MEATHERALL e cols ${ }^{99}$ relatam o caso de um indivíduo que ingeriu 39 pacotes contendo ao todo $518 \mathrm{gr}$ de óleo de haxixe, com teor de THC em torno de $24 \%$. Um pequeno extravasamento provocou a absorção de pelo menos 117 a $288 \mathrm{mg}$ de THC (doses efetivas por via oral são relatadas na literatura em torno de $15 \mathrm{mg}$, cerca de $1 / 3$ é absorvido ${ }^{142}$ ). Os teores de canabinóides encontrados na urina alcançaram a cifra de $10.000 \mathrm{ng} / \mathrm{ml}$. Apesar dos intensos efeitos observados, o estado clínico do indivíduo evoluiu bem após a remoção dos pacotes.

CHIANG e BARNETT 21 testaram o desempenho de pilotos em simuladores de vôo, mostrando a correlação entre concentração plasmática de THC e diminuição no desempenho, que continuava até aproximadamente 7 horas após a utilização de um cigarro de Cannabis.

KELLY e cols ${ }^{85}$ desenvolveram um programa de testes em computador para avaliar a diminuição no desempenho, e provaram efeitos significativos até o último teste realizado 3 horas após a exposição a um cigarro de Cannabis.

Por causa dos efeitos observados, existe um senso comum em relação a se evitarem tarefas que requeiram rápida tomada de decisão, julgamento e resposta motora instantânea, pelo menos poucas horas após a exposição à Cannabis. Mesmo assim, permanece ainda a incerteza em relação ao período exato de permanência desse efeito e de outras causas sinérgicas ( stress, má alimentação, etc.) ${ }^{75}$

Como já mencionado anteriormente, esse efeito da Cannabis é potencializado pelo álcool, e é grande a incidência desse tipo de interação nos acidentes de trânsito $50,65,52$

\subsubsection{Efeitos tóxicos a longo prazo}

É difícil determinar os efeitos nocivos da Cannabis no padrão de uso normalmente empregado, isto é, por pessoas relativamente saudáveis, em doses baixas, de modo intermitente, geralmente associada ao tabaco e/ou álcool53.

Muitos efeitos nocivos à saúde têm sido atribuídos ao uso crônico da Cannabis. Entre os mais comumente citados estão: interrupção nas funções celulares básicas, desequilibrio hormonal, interferência no sistema de defesa contra infecções, dano 
cromossomial, teratogênese, enfraquecimento do coração, danos oculares, acúmulo de THC no cérebro e testículos, dano cerebral, impotência e frigidez, câncer, dependência química e transposição para outras drogas. Tais efeitos, contudo, seriam reversiveis em semanas ou meses após a interrupção do uso da droga, não sendo possivel relacionar danos permanentes de ordem física ou psíquica 21,75,60,66,34,149.

STAFFORD ${ }^{128}$ discute trabalhos importantes realizados em populações que fazem uso intenso e crônico da Cannabis. Elas foram comparadas a populações-controle sob o ponto de vista psicológico, fisiológico, sociológico e antropológico. Não foi evidenciada uma maneira de diferenciar as duas populações. $O$ único achado clínico interessante foi a indicação de uma hipóxia funcional nos que fazem uso de mais de um cigarro de Cannabis por dia, durante vários anos.

Muito se discute sobre a relação entre os efeitos tóxicos da Cannabis alongo prazo e o desenvolvimento de uma personalidade agressiva e violenta. $O$ aumento da agressividade visto em experimentos com animais não pode ser usado para se predizer esse efeito no ser humano ${ }^{34}$. Alguns autores têm investigado esta relação com base em levantamentos epidemiológicos e estudos estatísticos.

DEMBO e cols ${ }^{33}$ realizaram um trabalho para detecção de usuários de drogas de abuso em uma casa de detenção de menores, através de análise de urina. Foram encontrados $41 \%$ de resultados positivos, sendo $30,6 \%$ relacionados a uso exclusivo de Cannabis, $4 \%$ de uso exclusivo de cocaina e o restante de uso de 2 ou mais drogas. 0 álcool não foi avaliado nesse estudo.

Segundo HOLLISTER ${ }^{60}$, possivelmente a Cannabis, tanto quanto o álcool, facilite o extravasamento de uma agressividade pré-existente.

KINGERY e cols 88 desenvolveram estudos comparativos entre estudantes e mostraram que os usuários de drogas de abuso se envolvem mais com situaçōes de risco que os não-usuários, o que os predispõem à violência quer como agentes, quer como vítimas.

Entre usuários crônicos de Cannabis existe alta prevalência de distúrbios de personalidade. Não se sabe se estes distúrbios foram provocados pelo uso crônico, ou se 0 uso crônico foi conseqüência deles, mas é certo que eles interagem sinergicamente ${ }^{34}$

CARLSON e EDWARDS 18 realizaram um estudo relacionando valores humanos com uso de Cannabis. Os autores observaram que alguns valores enfatizados no grupo de não-usuários, como o autocontrole, a responsabilidade e a prudência, não o eram no grupo de usuários. Estes priorizavam outros valores, como prazer, criatividade e vida excitante. 


\subsubsection{Toxicocinética}

Importantes trabalhos de revisão discorrem sobre a cinética da Cannabis $2,21,58,50$, não obstante, estudos mais recentes estabeleceram parâmetros pouco elucidados nos anteriores, principalmente pelo uso de técnicas analíticas mais sensíveis e seletivas. Para ordenar melhor esta exposição, podemos discutir a cinética em dois ambientes: no plasma e na urina.

\subsubsection{Perfil plasmático do $\triangle 9$-THC e seus principais produtos de biotransformação}

Os efeitos da Cannabis e de outras drogas fumadas precisam ser avaliados em termos de níveis plasmáticos, por causa da incapacidade de ser determinada uma dose especifica por esta via de exposição.

HUESTIS e cols 62 estudaram a cinética da Cannabis partindo de um volume pequeno de amostra $(0,5 \mathrm{ml}$ de plasma), de um rigoroso protocolo experimental e de um método analítico extremamente sensivel (CG/MS-NICl), validado para o $\Delta^{9}-\mathrm{THC}$ e seus mais importantes produtos de biotransformação (11-0H- $\Delta^{9}-\mathrm{THC}$ e 11-nor-9carboxi- $\Delta^{9}-\mathrm{THC}$ ).

Com auxílio de uma bomba de coleta contínua, foi possivel a obtenção de amostras em intervalos de tempo muito curtos, o que permitiu a caracterização da fase crítica de absorção que ocorre nos primeiros minutos da exposição.

A via de administração foi a pulmonar, por ser a mais usual. Variações individuais eram esperadas, de modo que os resultados foram expressos sob forma de valores médios, obtidos dentro de determinadas faixas. Infelizmente, as faixas de concentração são largas e se sobrepōem, reduzindo sua aplicabilidade na interpretação dos níveis plasmáticos.

Os resultados obtidos são apresentados de modo sintético na tabela 3 , sempre com valores médios de concentração e de momento de coleta de amostra. 
Tabela 3. Sintese dos resultados obtidos por HUESTIS e cols 40 referentes às concentrações plasmáticas encontradas após a utilização de Cannabis por via pulmonar.

\begin{tabular}{|c|c|c|c|c|}
\hline \multicolumn{3}{|c|}{ Momento da coleta } & $\begin{array}{l}\text { Concentração plasmática } \\
\text { (cigarro contendo } 1,75 \% \mathrm{THC} \text { ) }\end{array}$ & $\begin{array}{l}\text { Concentração plasmática } \\
\text { (cigarro contendo } 3,55 \% \text { THC) }\end{array}$ \\
\hline \multirow{2}{*}{\multicolumn{2}{|c|}{$\begin{array}{l}\text { Após 1@tragada } \\
\text { 2@ tragada }\end{array}$}} & $\rightarrow$ & $\cdot \mathrm{THC}=7 \mathrm{ng} / \mathrm{ml}$ & $\cdot \mathrm{THC}=18,1 \mathrm{ng} / \mathrm{ml}$ \\
\hline & & $\rightarrow$ & $\begin{array}{l}\cdot 11-\mathrm{OH}-\mathrm{THC} \text { detectado } \\
=6-10 \% \text { do } \mathrm{THC}\end{array}$ & $\begin{array}{l}\cdot 11-\mathrm{OH}-\mathrm{THC} \text { detectado } \\
=6-10 \% \text { do THC }\end{array}$ \\
\hline \multicolumn{2}{|c|}{$\begin{array}{l}\text { Após 7@tragada } \\
\mathrm{T}=8,4 \mathrm{~min}\end{array}$} & $\rightarrow$ & $\begin{array}{l}\text {-Pico THC }=84,3 \mathrm{ng} / \mathrm{ml} \\
\cdot \text { THCCOOH detectado } \\
\text {-11-OH-THC 6-10\% THC }\end{array}$ & $\begin{array}{l}\text {-Pico THC=162,2ng/ml } \\
\text {-THCCOOH detectado } \\
\text {-11-OH-THC 6-10\% THC }\end{array}$ \\
\hline$T=13 \mathrm{~min}$ & \multicolumn{2}{|l|}{$\rightarrow$} & $\begin{array}{l}\text {-Pico 11-OH-THC } \\
=6,7 \mathrm{ng} / \mathrm{ml}\end{array}$ & $\begin{array}{l}\text {-Pico 11-OH-THC } \\
=7,5 \mathrm{ng} / \mathrm{ml}\end{array}$ \\
\hline$T=15 \mathrm{~min}^{\star}$ & \multicolumn{2}{|l|}{$\rightarrow$} & $\begin{array}{l}\cdot \mathrm{THC}=52,3 \mathrm{ng} / \mathrm{ml} \\
\cdot 11-\mathrm{OH}-\mathrm{THC} 6-10 \% \mathrm{THC}\end{array}$ & $\begin{array}{l}\cdot \mathrm{THC}=94,8 \mathrm{ng} / \mathrm{ml} \\
\cdot 11-\mathrm{OH}-\mathrm{THC} 6-10 \% \mathrm{THC}\end{array}$ \\
\hline $\mathrm{T}=30 \mathrm{~min}^{*}$ & \multicolumn{2}{|l|}{$\rightarrow$} & $\begin{array}{c}\cdot \text { Pico THCCOOH } \\
=24,5 \mathrm{ng} / \mathrm{ml} \\
\cdot \mathrm{THC}=17,5 \mathrm{ng} / \mathrm{ml}\end{array}$ & $\begin{array}{c}\cdot \text { Pico THCCOOH } \\
=54 \mathrm{ng} / \mathrm{ml} \\
\cdot \mathrm{THC}=29,7 \mathrm{ng} / \mathrm{ml}\end{array}$ \\
\hline $\mathrm{T}=45 \mathrm{~min}$ & \multicolumn{2}{|l|}{$\rightarrow$} & $\begin{array}{l}\text { - THCCOOH - platô } \\
\text {-11-OH-THC cresce } \% \\
\text { devido à queda THC devic }\end{array}$ & $\begin{array}{l}\text { - THCCOOH - platô } \\
\text {-11-OH-THC cresce \% } \\
\text { lo à queda THC }\end{array}$ \\
\hline \multicolumn{2}{|l|}{$T=2$ horas } & & $\begin{array}{l}\cdot \text { THCCOOH platô 2-4h } \\
\cdot \text { THC < 5ng/ml } \\
\text { detectável 3-12 h } \\
\text {-11-OH-THC } \\
\text { detectável 4,5-11,2h }\end{array}$ & $\begin{array}{l}\text {-THCCOOH platô } 2-4 \mathrm{~h} \\
\cdot \text { THC próximo } 5 \mathrm{ng} / \mathrm{ml} \\
\text { detectável } 6-27 \mathrm{~h} \\
\text {-11-OH-THC } \\
\text { detectável } 4,5-11,2 \mathrm{~h}\end{array}$ \\
\hline \multicolumn{3}{|c|}{$T=24$ horas $\rightarrow$} & $\begin{array}{l}\text { - THCCOOH detectável } \\
\text { por } 48-168 \text { horas }\end{array}$ & $\begin{array}{l}\text {-THCCOOH detectável } \\
\text { por } 72-168 \text { horas }\end{array}$ \\
\hline \multicolumn{3}{|c|}{ AUC $0-168$ horas } & $\begin{array}{l}\cdot \mathrm{THC}=36,5 \mathrm{ng}-\mathrm{h} / \mathrm{ml} \\
\cdot 11-\mathrm{OH}-\mathrm{THC}=7 \mathrm{ng}-\mathrm{h} / \mathrm{ml} \\
\cdot \mathrm{THCCOOH}=401,4 \mathrm{ng}-\mathrm{h} / \mathrm{ml}\end{array}$ & $\begin{array}{l}\cdot \mathrm{THC}=72,2 \mathrm{ng}-\mathrm{h} / \mathrm{ml} \\
\cdot 11-\mathrm{OH}-\mathrm{THC}=14,7 \mathrm{ng}-\mathrm{h} / \mathrm{ml} \\
\cdot \mathrm{THCCOOH}=1146,5 \mathrm{ng}-\mathrm{h} / \mathrm{ml}\end{array}$ \\
\hline
\end{tabular}

* início do efeito psicoativo

$T=$ tempo médio de coleta

$\mathrm{THC}=\Delta^{9}$-tetrahidrocanabinol $; 11-\mathrm{OH}-\mathrm{THC}=11$-hidroxi- $\Delta^{9}$-tetrahidrocanabinol ;

$\mathrm{THCCOOH}=11$-nor-9-carboxi- $\Delta^{9}$-tetrahidrocanabinol

$A \cup C=$ área sob a curva 
A figura 1 representa a cinética plasmática para o cigarro de alta potência $(3,55 \% \mathrm{THC})$.

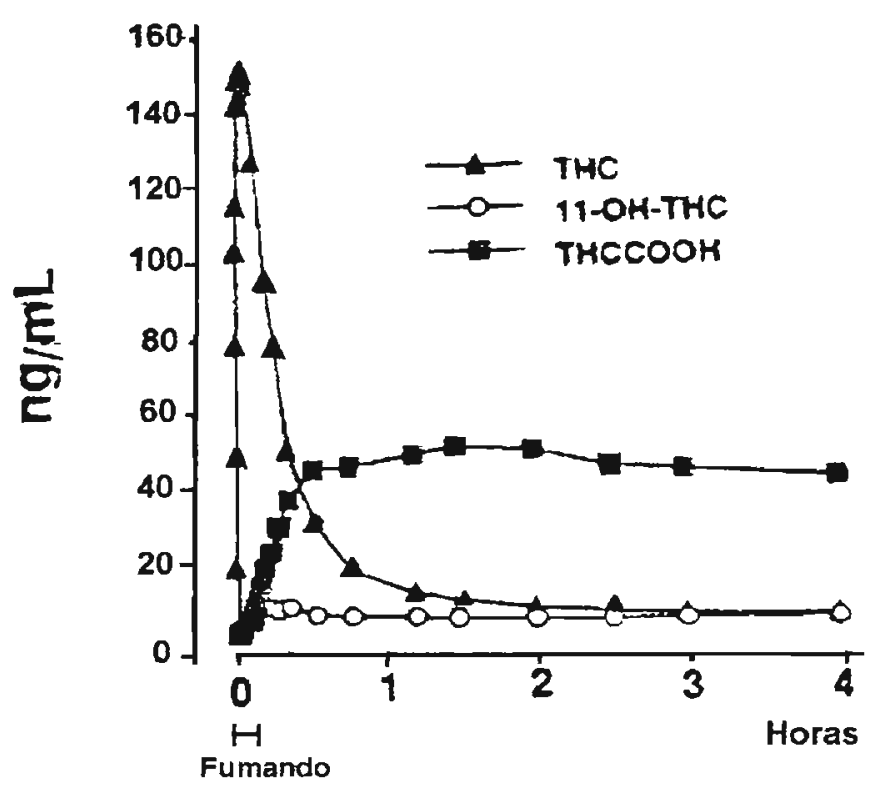

Figura 1. Niveis plasmáticos médios de 49 -tetrahidrocanabinol (THC), 11-hidroxi- $\Delta^{9}$-tetrahidrocanabinol (11-OH-THC) e 11-nor-9-carboxi- ${ }^{9}{ }_{-}$ tetrahidrocanabinol (THCCOOH), durante e após fumar um único cigarro de Cannabis contendo $3,55 \%$ de $\mathrm{THC}^{40}$

Logo após a primeira tragada, o $\Delta^{9}-\mathrm{THC}$ já é detectado no plasma, evidenciando uma absorção rápida por esta via de exposição. A biodisponibilidade é de 10-25\%, dependendo da habilidade do fumante. Por via oral, cerca de $90 \%$ da dose são absorvidos, contudo os níveis plasmáticos são baixos, devido ao efeito de primeira passagem hepática2.

A distribuição é bifásica. Inicialmente é rápida, em direção aos tecidos mais perfundidos e responsável pelo decaimento acentuado dos níveis plasmáticos de $\Delta^{9}$ THC. A segunda fase é lenta, em direção aos tecidos menos vascularizados 61 .

$0 \Delta^{9}-\mathrm{THC}$ circula firmemente ligado às proteínas, sendo de $3 \%$ a fração livre ${ }^{45}$. O clearance plasmático médio é de cerca de $0,8-0,9 \mathrm{l} / \mathrm{min}$, e o sangüíneo de 1,5-1,61/n 
$10 \mathrm{l} / \mathrm{Kg}^{21}$

O volume de distribuição no equilibrio é em torno de

Devido ao rápido decaimento do $\Delta^{9}-$ THC no plasma, os autores têm trabalhado mais na determinação do $t^{1 / 2} \beta$, fornecendo resultados não muito concordantes, devido às distintas condiçães experimentais e aos parâmetros de sensibilidade e especificidade das diferentes técnicas analíticas utilizadas ${ }^{2}$. Estudos mais recentes fornecem um valor $\operatorname{det}^{1 / 2} \beta=4.1 \operatorname{dias}^{84,62,70}$.

Seis horas após a exposição, os níveis plasmáticos nunca ultrapassam 2-3 $\mathrm{ng} / \mathrm{ml}$, e este poderia ser um valor limite para estabelecer uso recente de Cannabis, desde que validado por outros trabalhos e verificada a influência de altas doses, uso crônico e diferentes vias de absorção ${ }^{62,25}$.

O início do efeito psicológico ("high") foi relatado entre 15-30 minutos de exposição, depois de já terem sido alcançados os picos de concentração plasmáticas tanto do $\Delta^{9}$-THC quanto do 11-OH-THC. O mecanismo que explica este período de latência ainda não está totalmente elucidado, acontecendo o mesmo quando usada a via endovenosa ${ }^{2}$.

Os níveis de $11-\mathrm{OH}-\mathrm{THC}$ sempre atingem menos que $10 \%$ da concentração de $\Delta^{9}$-THC. Ele é produzido por hidroxilação microssonal e é farmacologicamente ativo. Quando utilizada a via oral ele pode até sobrepujar os niveis de THC devido ao efeito de primeira passagem, e seu período de detecção no plasma é bem maior 2,8,114.

A oxidação do 11-OH-THC, via citocromo $\mathrm{P}-450$, conduz à formação do derivado inativo, que é o 11-nor-9-carboxi- $\Delta^{9}-\mathrm{THC}(\mathrm{THCCOOH})^{139,140}$. Sua nomenclatura varia entre diferentes autores, existindo múltiplos números de registros no Chemical Abstract. Entre os nomes mais comuns estão: 11-nor- $\Delta 9$-tetrahydrocannabinol-9-carboxylic acid, 9-carboxy-11-nor- $\Delta$ 9-tetrahydrocannabinol, $\Delta$ 9-tetrahydrocannabinol-11-oic-acid e $\Delta 1$ tetrahydrocannabinol-7-oic-acid.

A concentração deste produto de biotransformação aumenta gradualmente e ultrapassa os niveis de $\Delta^{9}$-THC logo após cessar a exposição. Seu tempo de detecção é bem maior do que os dos THC e 11-OH-THC, isto como consequência da liberação lenta do $\Delta^{9}-\mathrm{THC}$ dos tecidos de depósito, com posterior biotransformação. $\mathrm{O} \Delta^{9}-\mathrm{THC}$ desaparece rapidamente do sangue junto com o 11-OH-THC; porém o THCCOOH, após atingir o pico, permanece num platô por um período de tempo relativamente maior, sendo ainda detectado vários dias após a exposição, mas em concentrações extremamente baixas 62 .

Devido às variações individuais, o uso de quocientes entre as concentrações plasmáticas do $\Delta^{9}-\mathrm{THC}$ e seus principais produtos de biotransformação pode ser útil para estimar o tempo de exposição e a presença de efeito farmacológico. Vários modelos de interpretação foram propostos $102,103,50,84,62,61$. Entretanto, BOGULZ ${ }^{13}$ alerta 
quanto à influência que podem ter concentrações residuais de $\mathrm{THCCOOH}$, fruto de exposições anteriores, sobre o cálculo do tempo de exposição.

KELLY e JONES ${ }^{84}$ relataram poucas diferenças entre usuários frequentes e ocasionais nos aspectos farmacocinéticos.

Estudos por via endovenosa confirmaram um perfil cinético semelhante à via pulmonar e diferente da via ora|58,2. A figura 2 mostra a diferença no perfil cinético quando utilizadas diferentes vias de exposição.
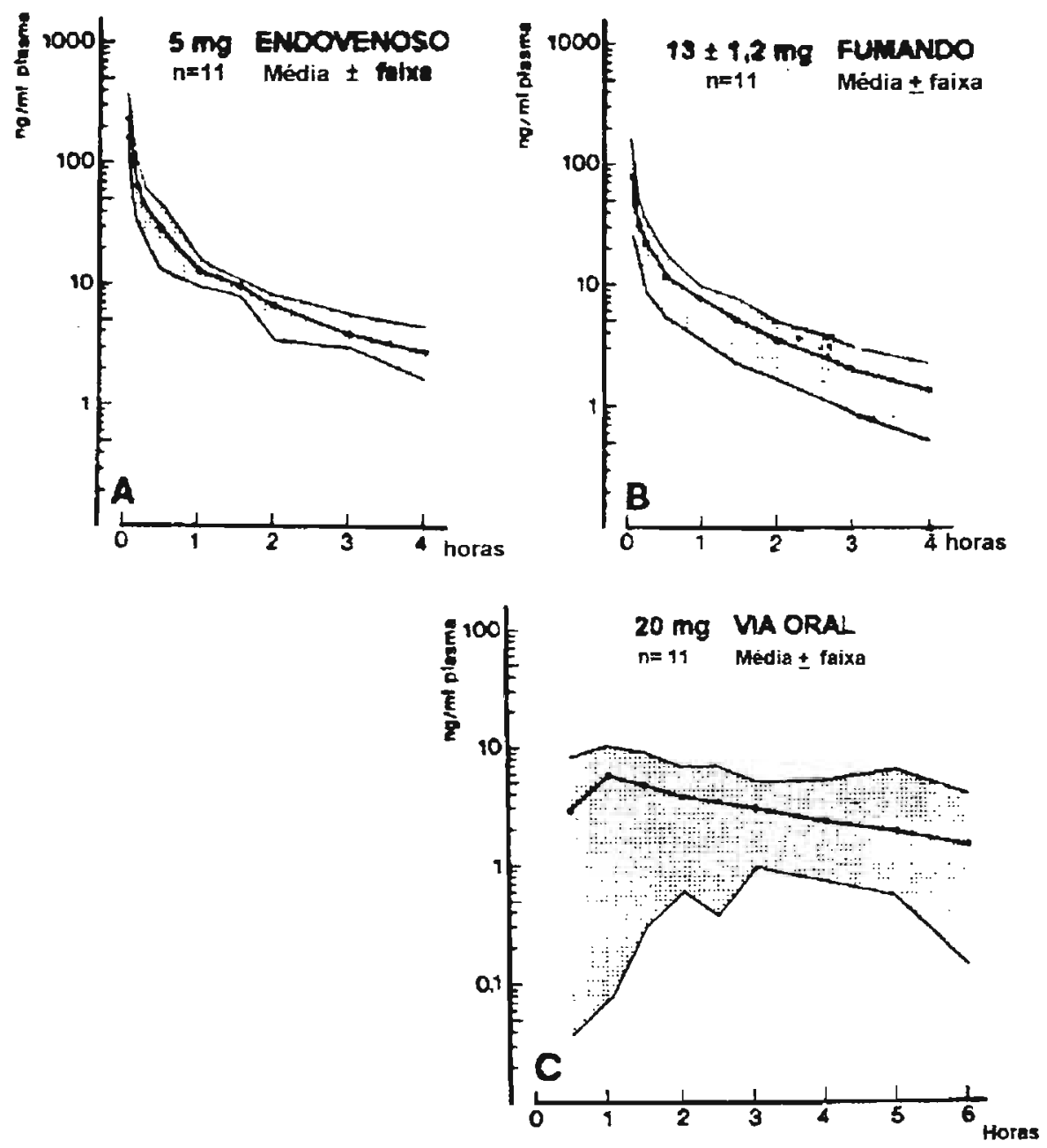

Figura 2. Média de 11 concentrações plasmáticas de THC obtidas durante 4 horas após a administração de $5 \mathrm{mg}$ I.V. (A), $13 \mathrm{mg}$ (valor médio, faixa 11,6-15,6mg) por via pulmonar(B), em um grupo de usuários de Cannabis: nivel plasmático médio após administração de $20 \mathrm{mg}$ de THC por via oral em um bolo de chocolate $(C)^{2}$ 


\subsubsection{Excreção urinária}

Segundo CHIANG ${ }^{21}$ e AGURELL2, cerca de $2 / 3$ da dose são excretadas pelas fezes e $1 / 3$ pela urina. A eliminação é lenta, de modo que $50 \%$ da dose são excretadas em 4-5 dias. Isto mostra a similaridade entre a $t^{1 / 2} \beta$ plasmática e a t $t^{1 / 2}$ aparente de eliminação ${ }^{8,84}$. JOHANSSON e cols ${ }^{71}$, trabalhando com $\Delta^{9}$-THC marcado com ${ }^{14} \mathrm{C}$, mostraram não existir diferenças significativas no perfil de excreção dos produtos totais de biotransformação, entre usuários ocasionais e frequientes, após fumar ou por via oral, sendo similar a t ${ }^{1 / 2}$ aparente de eliminação. A figura 3 mostra esses resultados.

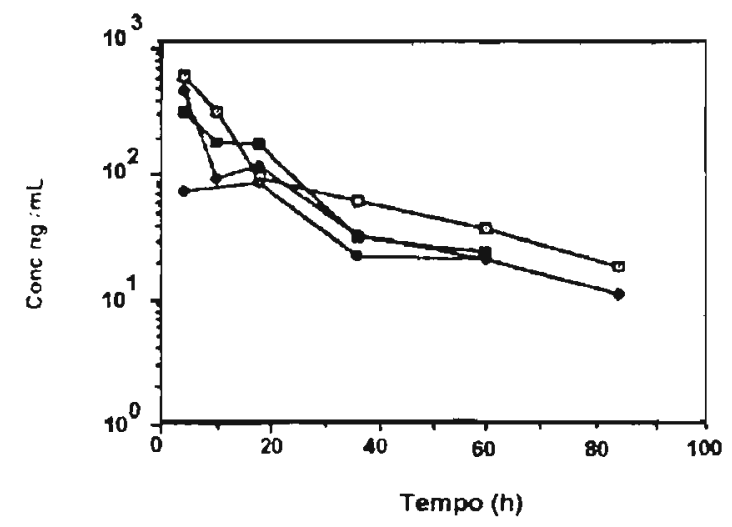

a) fumando

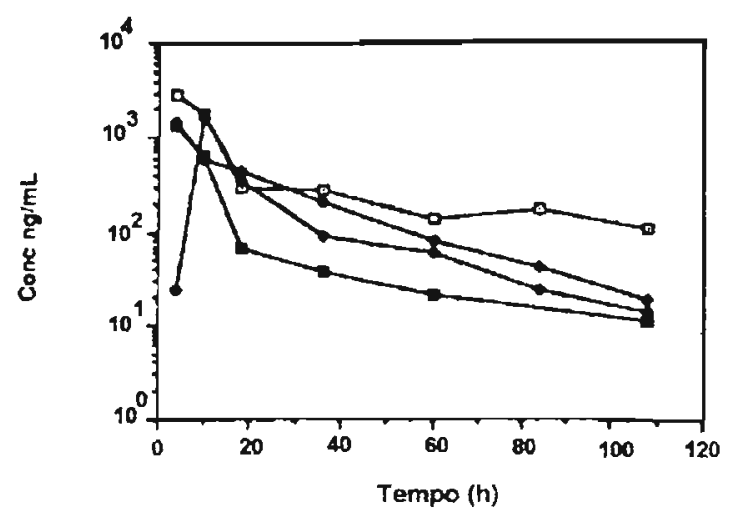

b) via oral

Figura 3. Excreção urinária dos produtos de biotransformação ${ }^{14} \mathrm{C}-\mathrm{THC}$ (calculado como ng de THC), após administração oral e pulmonar. Os símbolos cheios $(\mathbf{\square}, \bullet)$ se referem a usuários crónicos e os vazios $(O, \square)$ a usuários ocasionais ${ }^{71}$.

Mais de 24 produtos de biotransformação têm sido identificados na urina e fezes humanas, e existe uma fração significativa ainda não identificada. Todos os produtos de biotransformação identificados na urina do homem são de natureza ácida e eliminados preferencialmente sob forma conjugada ( glicuronídeos ). O mais abundante deles é o 11-nor-9-carboxi- $\Delta^{9}$-Tetrahidrocanabinol (THCCOOH), que conta com cerca de $27 \%$ no total eliminado2,21,3. 
A figura 4 mostra a estrutura química do $\Delta^{9}-T H C$ e de seus principais produtos de biotransformação.

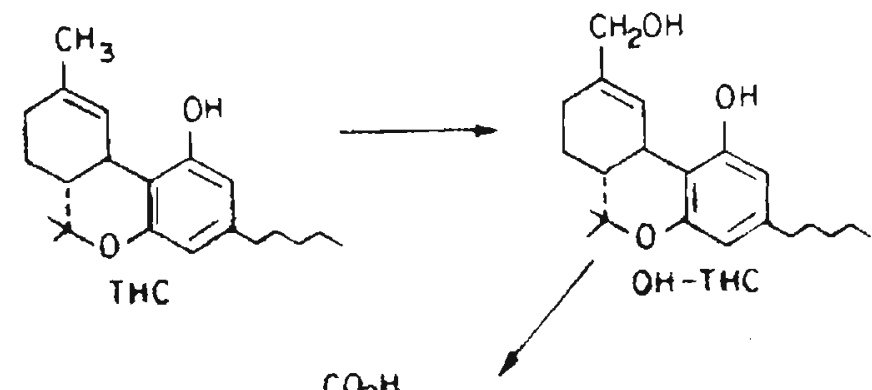<smiles>CCCc1cc(O)c2c(c1)OC(C)(C)CCC2C(=O)O</smiles><smiles>CCCc1cc(O)c2c(c1)OC(C)(C)C1CCC(C(=O)OCC)=CC21</smiles><smiles>CCCc1cc(OC)c2c(c1)OC(C)(C)[C@H]1CCC(C(=O)O)=CC21</smiles><smiles>CCCC1=CC2OC(C)(C)C3CCC(C(=O)OCC)=CC3C2C(OC)=C1</smiles>

GLICURONIDEOS

Figura 4. Principal via de biotransformação do $\Delta^{9}-T H C$ no homem ${ }^{114}$.

A conversão do THC para THCCOOH procede da formação de 11-OH-THC via citocromo P-450, com subseqüente oxidação para ácido carboxílico 139,140. Para realização da análise toxicológica, ele é o mais importante produto de biotransformação, por ser o mais abundante e ter maior período de detecção ${ }^{10}$.

A eliminação do $\mathrm{THCCOOH}$ inicia-se uma hora após a exposição. A concentração de sua forma livre é pequena e tende a diminuir à medida que a eliminação prossegue, até desaparecer completamente cerca de $8 \mathrm{~h}$ após a exposição, 
enquanto a fração conjugada tende a aumentar com o tempo, sendo a única forma encontrada após este período 79 .

ALBURGES e cols 3 verificaram que, em usuários crônicos, a concentração da forma livre é maior e ainda detectável até 24 horas após a exposição. Os autores sugerem saturação da glicuronil-transferase devido ao uso crônico.

Ao comparar a excreção de produtos de biotransformação totais com a eliminação do $\mathrm{THCCOOH}$, JOHANSSON e cols ${ }^{71}$ observaram perfis similares nos usuários ocasionais, porém nos usuários crônicos o perfil de eliminação do $\mathrm{THCCOOH}$ sofre influência de exposiçōes anteriores, sendo detectado em níveis mais elevados e por mais tempo. A figura 5 mostra esta diferença no perfil de eliminação entre usuários crônicos e ocasionais.

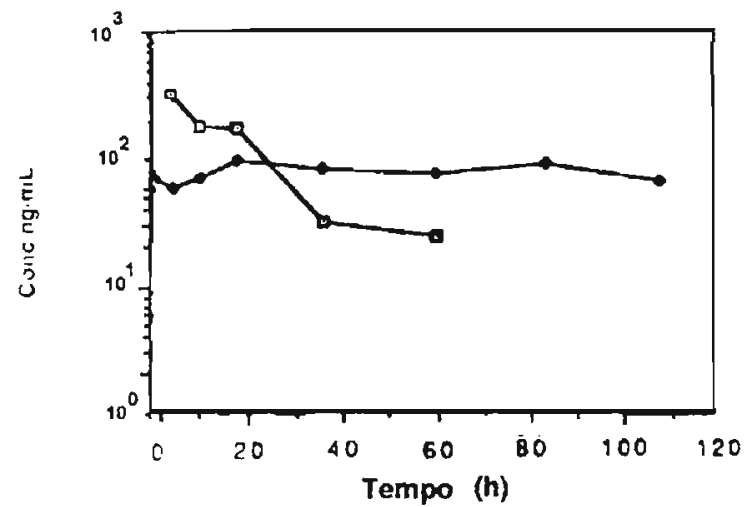

b) usuário crônico

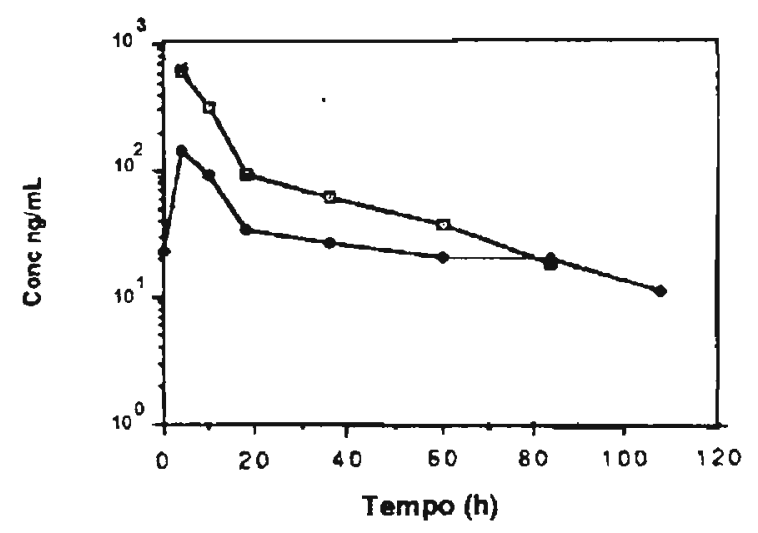

a) usuário ocasional

Figura 5. Excreção urinária do $\mathrm{THCCOOH}$ (simbolos cheios •) e produtos de biotransformação ${ }^{14} \mathrm{C}$ - $\mathrm{THC}$ (calculados como ng de $\mathrm{THC} / \mathrm{ml}$ de urina) em um usuário ocasional (a) e em um usuário crónico (b) após fumar 71.

O período de detecção do $\mathrm{THCCOOH}$ é muito variável, dependendo da dose, freqüência de uso, tempo da coleta da amostra, conteúdo de gordura corpórea, grau de diluição da urina e sensibilidade da técnica analítica utilizada10,95.

ELLIS e cols ${ }^{37}$ estudaram o periodo de detecção de canabinóides em urinas de 52 usuários de Cannabis, utilizando EMIT® com "cutoff" de $20 \mathrm{ng} / \mathrm{ml}$. Em termos de duração de resultados positivos, cerca de $60,6 \%$ dos usuários pesados tinham resultados positivos por mais de 21 dias após o último uso. Cerca de 1/3 tinha resultados positivos por mais de 30 dias, e $4,7 \%$ por mais de 60 dias. Em usuários 
ocasionais, o primeiro resultado negativo aparece em torno de 8,5 dias (faixa de 3-18) para um "cutoff" de 20ng/ml , ou 1 dia (faixa de 0-3) para o "cutoff" de 100 $\mathrm{ng} / \mathrm{ml}$.

MOODY e cols 25 tentaram correlacionar niveis de THCCOOH da urina e do sangue na avaliação do tempo de exposição. Eles verificaram que usuários crônicos alcançam concentrações mais altas de THCCOOH em menos tempo. Se não for conhecida a hora da coleta e a dose utilizada, e levando em conta a existência de variações individuais, 0 fato de conhecermos a concentração dos produtos de biotransformação não é suficiente para se predizer a hora do uso e o momento do efeito tóxico para um dado indivíduo. 


\subsection{Aspectos Analíticos}

\subsubsection{Quanto à amostra.}

Pelas características farmacocinéticas da Cannabis, podemos classificar os fluidos biológicos para análise de canabinóides em 2 tipos: os que expressam somente exposição recente, e os que podem expressar exposições anteriores. Entre as amostras que expressam apenas uso recente se enquadram a saliva, 0 ar expirado e o sangue, este último merecendo consideraçōes especiais.

As vantagens do uso da saliva como amostra estão no fato de ela ser obtida por método não invasivo e de ser facilmente disponível a qualquer momento. Contudo, em relação à análise de canabinóides, a saliva oferece algumas desvantagens. Os niveis elevados de ligação protéica do $\Delta^{9}-\mathrm{THC}$ e 11-OH-THC tornam pouco provável que a presença destes na saliva seja por transferência do sangue para a saliva; foi observada adsorção de canabinóides na cavidade oral durante o ato de fumar. Concentrações de 5-330 ng/ml podem ser encontradas até 8 horas após fumar um cigarro de Cannabis, e o período de detecção é de no máximo 14 horas após a exposição. Além disso, o uso de Cannabis inibe a secreção salivar ${ }^{121,45}$.

A presença do $\Delta^{9}$-THC no ar expirado é devida provavelmente à liberação lenta da droga seqüestrada pelos pulmões, e seu período de detecção é curto, apenas algumas horas após a exposição 59 .

O sangue é a única amostra que oferece boa correlação entre concentração e efeito farmacológico, no entanto, as baixas concentrações dos analitos no sangue impōem o uso de técnicas sofisticadas e muito sensiveis ${ }^{11}$. Seis horas após a exposição, os níveis plasmáticos do $\Delta^{9}-\mathrm{THC}$ nunca ultrapassam 2-3 ng/ml e este pode ser um valor limite para estabelecer uso recente. Contudo, o sangue também contém THCCOOH por um tempo relativamente longo dependendo da sensibilidade do método analítico utilizado, e para este analito, a simples detecção pode não corresponder a uso recente ${ }^{62}$.

Entre as amostras que podem expressar exposições anteriores se enquadram a urina e, especialmente, o cabelo.

A urina é o fluido biológico de eleição na análise de drogas de abuso. Está menos sujeita à interferência de compostos lipofílicos que o sangue. Volumes adequados são obtidos facilmente, por técnica não invasiva. Pela via mais comum de uso da Cannabis (via pulmonar), altos teores de $\mathrm{THCCOOH}$ são encontrados na urina, $e$, dependendo da freqüência de uso da droga, o período de detecção vai de 3 a 20 dias ou mais $129,45,119,121$. 
Poderíamos citar, como desvantagem na utilização da urina como amostra, a quebra de privacidade no ato de coleta, tendo em vista a necessidade de um observador, a fim de evitar prováveis adulterações ${ }^{121}$.

Recentemente, tem sido dada maior atenção ao cabelo como amostra para detecção de drogas ilícitas. As drogas passam dos fluidos circulantes para o cabelo e permanecem firmementes ligadas a ele. É possível, então, acompanhar a ingestão da droga por periodo maior que 6 meses, dependendo do tamanho do cabelo. Mesmo que o usuário se abstenha da droga por um período maior que o de detecção na urina, a análise de fragmentos de cabelo pode, entretanto, fornecer resultado positivo.

Até o presente momento, apenas dois métodos analíticos têm tido sensibilidade suficiente para ser empregado nesta análise: radioimunoensaio e CG/MS. KINTZ e cols ${ }^{89}$ sugerem o uso de imunoensaio de polarização de fluorescência ( $A D \times(\mathbb{B})$, para triagem de amostras de cabelo. Utilizando como cutoff a concentração de $25 \mathrm{ng} / \mathrm{ml}$, não ocorreram falsos positivos para canabinóides, sendo observados apenas 2 falsos positivos entre 29 casos reportados como positivos pelo ADX e confirmados por CG/MS.

\subsubsection{Quanto à estabilidade de canabinóides.}

Vários fatores interferem na estabilidade dos canabinóides. Dentre estes estão o oxigênio, o calor, o solvente empregado na dissolução $e$, principalmente, a luz $59,41,126,133$. Na preparação de soluçōes-padrão, é recomendado o emprego de etanol como solvente, frascos de vidro âmbar e armazenamento em temperaturas inferiores a zero graus 41,126 .

HARVEY e cols 58 relatam a influência do $\mathrm{pH}$ para a estabilidade dos canabinóides. Em meio fortemente ácido ( $\mathrm{pH}<4$ ) observa-se a degradação de muitos canabinóides, o oxigênio do anel pirânico é protonado, causando abertura do anel e formação de vários canabinóides substituídos 59 .

Os canabinóides ácidos são instáveis, principalmente diante da luz e do calor, sofrendo descarboxilação com passagem para os canabinóides neutros correspondentes ${ }^{126}$. FAIRBAIRN e cols ${ }^{41}$ sugerem que o efeito da luz pode converter os canabinóides em polímeros que não são detectados pelas técnicas usuais de cromatografia gasosa e em camada delgada.

A estabilidade de canabinóides em fluidos biológicos também foi estudada. Alguns autores preconizam o uso de conservantes tipo fluoreto de sódio e oxalato de potássio, não observando degradação de canabinóides quando as amostras de sangue eram armazenadas a $4^{\circ} \mathrm{C}$ em tubos Vacuotainer ${ }^{102,50}$. 
FOLTZ45 estudou a estabilidade do $\triangle^{9}-\mathrm{THC}, 11-\mathrm{OH}-\mathrm{THC}$ e THCCOOH em sangue e plasma estocados em frascos de vidro, a temperatura ambiente, $4^{\circ}$ e $-10^{\circ} \mathrm{C}$. JOHNSON e cols 72 trabalharam com frascos sinalizados e usaram CG/MS-NICl para quantificação dos níveis dos analitos. Ambos relatam boa estabilidade até 30 dias em qualquer das condições de estocagem. Após este período inicia-se a degradação do THC e 11-OH-THC apenas nas amostras deixadas a temperatura ambiente; podendo gerar perda de $90 \%$ do THC e $44 \%$ do $11-\mathrm{OH}-\mathrm{THC}$ no sexto mês de estocagem. Para o THCCOOH não foi observado decréscimo significativo.

Em relação à urina, trabalhos realizados com avaliação de amostras por técnicas imunológicas mostraram boa estabilidade para as urinas congeladas a $-20^{\circ} \mathrm{C}$. Resultados positivos ainda eram observados após um ano de estocagem ${ }^{5}$. KING e cols ${ }^{86}$ observaram que de 107 amostras na faixa de $20-185 \mathrm{ng} / \mathrm{ml}$, apenas 11 ficaram abaixo de $20 \mathrm{ng} / \mathrm{ml}$ após 18 meses de armazenamento no freezer.

SUTHEIMER e cols ${ }^{131}$ analisaram por EMITß um grupo de amostras de urinas divididas em 4 subgrupos: negativas, <20ng/ml, entre $20-100 \mathrm{ng} / \mathrm{ml},>400 \mathrm{ng} / \mathrm{ml}$. Estas amostras foram estocadas por 3 semanas a temperatura ambiente, $4^{\circ}$ e $-20^{\circ} \mathrm{C}$. Alguma deterioração já era vista a partir do quarto dia nas amostras deixadas a temperatura ambiente, sendo maior a instabilidade na faixa de $20-100 \mathrm{ng} / \mathrm{ml}$. As amostras refrigeradas e congeladas permaneceram estáveis.

Segundo FOLTZ ${ }^{88}$, O THCCOOH em urina pode diminuir em até $50 \%$ após 30 dias de estocagem a $4^{\circ} \mathrm{C}$ ou a temperatura ambiente. A mesma pesquisa mostra que 0 $\mathrm{THCCOOH}$ pode concentrar-se nos sedimentos que se formam na urina estocada ou na espuma que se forma quando ocorre agitação vigorosa da amostra.

JOHANSSON e cols ${ }^{71}$ trabalharam com amostras de urina acidificadas $e$ congeladas em frascos de vidro sinalizados, uma vez que não ocorreria degradação de canabinóides se a urina fosse estocada nestas condições.

Em estudo de proficiência feito pela American Association of Clinical Chemistry (AACC), FRINGS e cols ${ }^{48}$ relataram que no modo como as amostras são acondicionadas ( frascos de vidro com rolha de borracha) não foi observada degradação de fármacos e produtos de biotransformação, incluindo o $\mathrm{THCCOOH}$.

PAUL e cols ${ }^{111}$ estudaram o efeito do congelamento sobre a concentração de drogas de abuso em urina. Usando tubos de polipropileno, armazenou urinas adicionadas de $\mathrm{THCCOOH}$ a $-18^{\circ} \mathrm{C}$ por periodo de 45 dias. A análise por CG/MS revelou perda média de $11 \%$ nos níveis de $\mathrm{THCCOOH}$. Experimento similar conduzido sem 0 congelamento das amostras não revelou perdas significativas. $O$ autor atribui esta perda ao fenômeno de adsorção, provocado pela natureza lipofílica do analito e por sua baixa solubilidade na temperatura de congelamento. 
Observação similar foi feita por JOERN69 trabalhando com frascos de vidro. Esse autor defende a preparação de controles com pH alcalino e diz que são estáveis por 18 meses a $-80^{\circ} \mathrm{C}$, mesmo armazenando em frascos de vidro não silanizados.

LAW e cols ${ }^{93}$ estudaram a estabilidade do $\mathrm{THCCOOH}$ conjugado ao ácido glicurônico. O glicuronídeo sofre parcial ou total hidrólise a $\mathrm{pH}$ maior que 8 , tanto refrigerado a $4^{\circ} \mathrm{C}$ quanto a temperatura ambiente, gerando o $\mathrm{THCCOOH}$ livre.

CHRISTOPHERSEN22 também estudou a estabilidade de canabinóides em fluidos biológicos e observou boa estabilidade nas condiçōes em que as amostras são habitualmente acondicionadas nos procedimentos da investigação médico-legal.

\subsubsection{Quanto à separação e extração do THCCOOH da urina}

Como relatado anteriormente, $0 \mathrm{THCCOOH}$ na urina se encontra predominantemente sob forma conjugada, levando a grande maioria dos autores a submeter as amostras de urina a uma etapa de hidrólise antes da extração.

Segundo ELSOHLY40 a hidrólise alcalina é mais eficiente e reprodutivel do que a hidrólise ácida ou enzimática. A hidrólise enzimática é pouco empregada, sendo o custo elevado da enzima $\beta$-glicuronidase um dos fatores limitantes ao seu emprego. Outro, é que a enzima precisa ser continuamente examinada quanto à sua atividade ${ }^{6}$.

A hidrólise alcalina em geral é realizada com $\mathrm{NaOH}$ ou $\mathrm{KOH}$, variando entre os autores a concentração final do álcali na amostra. Quando se usa $\mathrm{NaOH}$, seja $1 \mathrm{~N}^{98,105}$, $6 N^{135}$ ou $10 N^{90,144}$, o volume do álcali geralmente corresponde a $10 \%$ do volume da amostra. Já o $\mathrm{KOH} 10 \mathrm{~N}$ tem sido empregado em volumes correspondentes a $5 \%{ }^{110} \mathrm{e}$ $10 \%{ }^{10,50}$ do volume da amostra. A hidrólise com $\mathrm{KOH}$ parece produzir extratos mais limpos, sendo preferida quando se destina ao uso de CG ou CG/MS45.

As condições ideais para a hidrólise alcalina foi estudada por VINSON e LOPATOFSKY135 e estão de acordo com a conduta utilizada pela grande maioria dos autores, isto é, temperatura entre $50-60^{\circ} \mathrm{C}$ e tempo necessário para liberação do THCCOOH entre 15-20 minutos. Alguns autores preconizam o uso de temperaturas mais elevadas $90,144,105$.

A instabilidade do glicuronídeo em $\mathrm{pH}$ fortemente alcalino levaram $\mathrm{KING}^{86} \mathrm{e}$ MCCURDY97 a realizar a hidrólise em temperatura ambiente, usando $\mathrm{KOH} 11,8 \mathrm{~N}$ em quantidade correspondente a $10 \%$ do volume da amostra. Eles relatam um tempo de apenas 5 minutos para que a hidrólise se processe. 
KANTER ${ }^{80}$ e WALL e cols ${ }^{136}$ relatam que éter etílico extrai o glicuronídeo em $\mathrm{pH}$ menor ou igual a 4, dispensando a etapa de hidrólise.

A grande maioria dos métodos cromatográficos para detecção de $\mathrm{THCCOOH}$ em urina não dispensam a fase de extração, excetuando-se os métodos de LAW e cols ${ }^{93}$ e KING e cols ${ }^{86}$. A extração do THCCOOH do sangue ou urina pode ser feita por extração líquido/líquido ou sólido/liquido.

Entre as vantagens de se trabalhar com extração sólido/liquido, está a possibilidade de se reduzir a quantidade de impurezas químicas presentes na amostra, e de processar várias amostras simultaneamente. A presença de dois grupos funcionais ácidos no THCCOOH faz da troca aniônica uma escolha preferida entre colunas de extração1; ácidos endógenos, entretanto, podem ser de difícil remoção. Colunas de fase reversa têm sido também empregadas.

Muitos trabalhos foram realizados com extração sólido/líquido, usando vários tipos diferentes de colunas $97,64,135,90,144,110,10,42$. Variações entre lotes de colunas podem causar problemas na reprodutibilidade entre os laboratórios ${ }^{15}$.

A extração líquido/líquido de canabinóides naturais, presentes na planta e também em fluidos biológicos, era tradicionalmente feita pelo solvente de Brodie (álcool isoamílico 1,5\% em hexano ).Em publicações posteriores foi relatado que o uso isolado de hexano extrai canabinóides naturais de modo eficiente, e fornece extratos limpos, 0 que permite aplicação direta em cromatografia de fase gasosa $82,98,15$.

$O$ éter etílico também foi muito empregado78,80,136, e o acetato de etila pode ser usado para extrair uma grande quantidade de produtos de biotransformação e seus conjugados de fluidos biológicos e tecidos 59 .

Outros solventes e combinações de solventes podem ser empregados na extração líquido/liquido para o $\mathrm{THCCOOH}^{50,77}$, sendo mais freqüentemente utilizada a mistura hexano:acetato de etila $6,23,105,97,10$.

Extraçōes conduzidas com clorofórmio, diclorometano, acetato de etila, metil-tercbutil-éter, e hexano:álcool isoamílico 95:5, resultam em resíduo com presença de interferentes que prejudicam a fase de identificação por CCDAE98.

Entre todos os solventes, o hexano é o mais utilizado, sozinho ou combinado com acetato de etila ou isobutanol. Entretanto, MEATHERALL98 relata que a mistura de solventes não se mostrou mais eficiente e arrasta mais impurezas.

A extração é realizada em meio ácido, geralmente em pH igual ou menor a 4. Os ácidos mais utilizados são: $0 \mathrm{HCl}$ concentrado ou em soluções de normalidades variadas, e o ácido acético glacial.

Os autores relatam tempos de extração que variam entre 5-30 minutos, preferencialmente com agitação mecânica, suave ou moderada. Após centrifugação, o 
solvente é separado e evaporado. Poucos autores trabalham com purificação por retroextração ${ }^{108,50}$.

As condições de evaporação do solvente também variam entre os autores. A maioria utiliza nitrogênio ou corrente de ar seco para acelerar o processo, sem aquecimento ou entre $50-60^{\circ} \mathrm{C}$. O recipiente onde vai ser evaporado o solvente para obtensão do resíduo de extração pode ser de fundo cônico ou arredondado, desde que observados todos os cuidados na recuperação do resíduo das paredes do tubo98.

A questão de usar vidraria silanizada ou não é discutida por alguns autores. Para sangue prevalece esta necessidade, já que neste fluido os canabinóides estão presentes em concentraçōes muito baixas, e qualquer adsorção pode ocasionar uma perda importante para a análise ${ }^{59}$.

MEATHERALL98 afirma que, após evaporação, vários solventes são capazes de recuperar todo $\mathrm{THCCOOH}$ do resíduo, se a vidraria for silanizada (clorofórmio, diclorometano, acetato de etila, metanol, etanol ,acetona). Caso não seja silanizada, somente os álcoois ou misturas de clorofórmio ou diclorometano que contenham no mínimo $5 \%$ de etanol ou metanol são capazes de recuperar todo o $\mathrm{THCCOOH}$. Trabalhando com mistura de clorofórmio:metanol 3:1, ele conseguiu excelente recuperação do resíduo para aplicação em CCDAE, sem precisar trabalhar com vidraria silanizada.

Se o resíduo não puder ser aplicado à cromatoplaca no mesmo dia, ele pode ser guardado até por 48 horas, sem que haja perda significativa nos teores de $\mathrm{THCCOOH}^{98}$. 
2.2.4 Identificação do THCCOOH por cromatografia em camada delgada

A detecção e quantificação de canabinóides nos fluidos biológicos por CCD apresenta maior dificuldade do que em plantas ou resinas, devido à menor concentração encontrada e à presença de outros compostos co-extraídos do meio biológico 59 .

Em 1974, KANTER e HOLLISTER ${ }^{81}$ isolaram o mais importante produto de biotransformação do THC, através da análise de urina em CCD. Estudos com cromatografia gás-liquido e espectrometria de massa não foram conclusivos quanto à sua estrutura química; sabiam porém, que não se tratava de nenhum canabinóide até então conhecido. Este produto só foi corretamente identificado quando o THCCOOH sintetizado se tornou disponível comercialmente como padrão, a partir de 1975. Desde então, outros pesquisadores demonstraram a presença de $\mathrm{THCCOOH}$ em urina de usuário de Cannabis.

Vários trabalhos em CCD foram realizados, variando o tipo de placa, o sistema solvente e agente cromogênico. Na tabela 4 são apresentados alguns trabalhos a que se teve acesso na literatura. Com exceção do método de KING e cols ${ }^{86}$, onde se faz aplicação direta da urina em placa especial, todos os trabalhos utilizam volumes de amostra iguais ou superiores a $10 \mathrm{ml}$.

Tabela 4. Alguns sistemas cromatográficos utilizados na identificação de $\mathrm{THCCOOH}$ por cromatografia em camada delgada.

\begin{tabular}{|c|c|c|c|}
\hline Sistema solvente & Ag.Cromog. & Sensibilidade & Ref/ano \\
\hline $\begin{array}{l}\text { Acetona:Clorofórmio: Trietilamina 80:20:1 } \\
\text { Éter petroleo:éter:ác. acét. glacial 50:50:1 }\end{array}$ & Fast Blue B & 0,5 ug & $78(1981)$ \\
\hline $\begin{array}{l}\text { Clorofórmio:metanol:hidróxido de amônio } \\
85: 15: 2\end{array}$ & Fast Blue RR & $\begin{array}{l}50-100 \mathrm{ng} / \mathrm{ml} \\
\mathrm{p} / 20 \mathrm{ml} \text { amostra }\end{array}$ & $77(1982)$ \\
\hline $\begin{array}{l}\text { Clorofórmio:metanol:hidróxido de amônio } \\
70: 30: 2\end{array}$ & Fast Blue B & - & 107(1983) \\
\hline $\begin{array}{l}\text { Acet. Etila:Metanol:água:hidróxido amônio } \\
2: 5: 0,5: 1\end{array}$ & Fast Blue RR & $\begin{array}{l}20 \mathrm{ng} / \mathrm{ml} \\
\mathrm{p} / 10 \mathrm{ml} \text { amostra }\end{array}$ & $90(1984)$ \\
\hline Heptano:acetona:ác. acét.glacial $70: 30: 1$ & Fast Blue BB & $\begin{array}{l}<20 \mathrm{ng} / \mathrm{ml} \\
\mathrm{p} / 10 \mathrm{ml} \text { amostra }\end{array}$ & $\begin{array}{c}47,131,122 \\
(1985 / 87)\end{array}$ \\
\hline Heptano:acetona:ác. acét.glacial 50:50:1 & Fast Blue BB & $\begin{array}{l}20 \mathrm{ng} / \mathrm{ml} \\
\mathrm{p} / 3 \mathrm{ml} \text { amostra }\end{array}$ & $86(1989)$ \\
\hline
\end{tabular}




\subsubsection{Influência da fase estacionária}

Como se pode observar na tabela 4 , o desenvolvimento nos métodos para $C C D$ caminhava em busca de maior sensibilidade. Como em qualquer técnica de $C C D$, a sensibilidade é parcialmente governada pela fase estacionária e pelo agente cromogênico empregado. Com o advento da cromatografia em camada delgada de alta eficiência, temos disponivel uma fase estacionária que permite ganho considerável de sensibilidade.

A cromatografia em camada delgada de alta eficiência (CCDAE) teve sua origem no desenvolvimento de pequenas partículas para a cromatografia líquida de alta eficiência (CLAE). Estas partículas foram inicialmente recomendadas para a cromatografia em camada delgada (CCD) por HANS GEHRKE ( Darmstadt, Germany) no início dos anos 70. Entretanto, só em 1975 é que R.E. KAISER mostrou sua aplicabilidade, passando à comercialização57.

As placas de CCD são tipicamente manufaturadas com partículas de aproximadamente 10-12 $\mathrm{m} \mu$; as placas de CCDAE são produzidas com partículas de 5-7 mu. Enquanto a CCD alcança de 80-1000 pratos teóricos $(\mathrm{N})$ em $15 \mathrm{~cm}$ de percurso, a CCDAE alcança $3000 \mathrm{~N}$ em $5 \mathrm{~cm}$. Segundo GURKIN 57 , muitos analistas reconhecem que alcançando este número de pratos teóricos é possivel obter resultados analíticos comparáveis com análise em cromatografia líquida de alta eficiência (CLAE) . Além disso, o uso da CCDAE elimina muitos dos processos e custos associados com purificação de amostras e pré-tratamentos requeridos para preservar as caras colunas de CLAE.

Dependendo do tamanho da placa e das condições analíticas é possível analisar várias amostras simultaneamente, dispensando o uso de equipamentos e acessórios caros.

As placas de CCDAE são mais finas que as de CCD. $O$ consumo de solventes para CCDAE também é substancialmente menor do que na CCD convencional. Nas placas de CCDAE a cromatografia ocorre numa faixa rápida de fluxo capilar da fase móvel. Isto explica todas as vantagens da CCDAE sobre a CCD, como, por exemplo, rapidez de separação, difusão reduzida, gerando aumento na eficiência da separação, e limite de detecção menor 57 .

O poder de separação na CCD é consideravelmente menor do que nos outros métodos cromatográficos como cromatografia gasosa (CG) e CLAE. Isto ocasiona problemas com a separação de interferentes. A CCDAE, tendo um poder maior de resolução do que a CCD convencional, atenua esta questão de interferentes ${ }^{135}$. GÜBITZ 
e WINTERSTEIGER 55 relataram o uso da CCDAE como técnica de triagem para várias drogas de abuso, utilizando a urina como amostra.

A primeira referência quanto ao uso da CCDAE na detecção de $\mathrm{THCCOOH}$ em urina de usuários de maconha data de 198412. Mais tarde, este mesmo grupo de pesquisadores utilizou esta metodologia em CCDAE junto com CLAE, para confirmar resultados positivos no EMIT $\mathbb{B}^{4}$

Na revisão bibliográfica realizada, foram encontrados mais dois trabalhos: em 1985, VINSON e LOPATOFSKY135 e, posteriormente, MEATHERALL e GARRIOTT'98. Na tabela 5 estão listados os aspectos cromatográficos destes trabalhos.

Tabela 5. Sistemas cromatográficos utilizados na deteç̧ão de THCCOOH por CCDAE

\begin{tabular}{|c|c|c|c|c|}
\hline Tipo de placa & Sistema solvente & Ag.Cromog. & Sensibilidade & Ref \\
\hline $\begin{array}{l}\text { HPTLC-HL } \\
\text { (Analtech) }\end{array}$ & $\begin{array}{l}\text { Hexano:acetona:ác.acét.glacial } \\
70: 30: 1\end{array}$ & Fast Blue B & $\begin{array}{l}20 \mathrm{ng} / \mathrm{ml} \mathrm{p} / \\
10 \mathrm{ml} \text { amostra }\end{array}$ & 12,64 \\
\hline $\begin{array}{l}\text { LHP-K } \\
\text { (Whatman) }\end{array}$ & $\begin{array}{l}\text { Heptano:éter:ác. acét.glacial } \\
80: 10: 4\end{array}$ & Fast Blue BB & $\begin{array}{l}2 \mathrm{ng} / \mathrm{ml} \mathrm{p} / \\
2 \mathrm{ml} \mathrm{amostra}\end{array}$ & 135 \\
\hline $\begin{array}{l}\text { HPTLC-HLR } \\
\text { (Analtech) } \\
\text { LHP-KF } \\
\text { (Whatman) } \\
\text { HPTLC-60 F250 } \\
\text { (Merck) }\end{array}$ & $\begin{array}{l}\text { Heptano:n-butanol: ác. acét. glacial } \\
90: 9: 1 \\
0\end{array}$ & Fast Blue BB & $\begin{array}{l}5 \mathrm{ng} / \mathrm{ml} \mathrm{p} / \\
2 \mathrm{ml} \text { amostra }\end{array}$ & 98 \\
\hline
\end{tabular}

\subsubsection{Influência da fase móvel}

A seleção da fase móvel envolve vários fatores. Cada trabalho discute a sua própria escolha dentro de condições analíticas específicas. Interessante é a discussão de MEATHERALL e GARRIOTT 98 para a escolha do sistema solvente aplicado a CCDAE.

Na fase móvel utilizada (n-heptano:n-butanol:ác.acético glacial 90:9:1), $\Delta^{9}$-THC, CNB e CBD aparecem juntos, porém separados do THCCOOH. Quanto à distância de migração do $\mathrm{THCCOOH}$, não houve alteração cromatográfica quando hexano foi substituido por heptano e o pentano provocou menor distância de migração do THCCOOH. Isopropanol e n-propanol produziam bandas mais difusas. Butanol 
apresentou melhores resultados na separação do $\mathrm{THCCOOH}$ de outros canabinóides em relação ao hexanol, álcool amílico e isoamílico.

$\mathrm{O}$ emprego do ácido acético mantém um pH reprodutivel na fase móvel e previne a dissociação do $\mathrm{THCCOOH}$ durante a migração. Sem a inclusão deste, a banda do $\mathrm{THCCOOH}$ tem aspecto "difuso" e migra pouco. $\mathrm{O}$ ácido acético influencia diretamente $\mathrm{O}$ hRf do THCCOOH. KANTER 78 também observou a influência do ácido acético no sistema solvente. Na concentração de $1 \%$ o canabinóide migrava pouco, com $2 \%$ o canabinóide alcançava a zona de material endógeno. $O$ autor, então, escolheu a concentração de $1,5 \%$.

Apesar da aplicação pontual, as manchas de canabinóides visualizadas em CCDAE tem formato de bandas bem definidas. Este comportamento é devido unicamente à fase móvel, especialmente pela presença do ácido acético ${ }^{98}$.

\subsubsection{Estudo da deteç̧ão do THCCOOH}

Como se disse anteriormente, não só a fase estacionária, mas também o agente cromogênico governam a sensibilidade. A deteç̧ăo de canabinóides apresenta uma certa complexidade ligada a vários fatores: o tipo do cromógeno, sua basicidade e a presença residual de solvente na placa96,135,98.

A reação colorimétrica mais especifica e a preferida para trabalhos com CCD e CCDAE envolvem a reação de canabinóides com o corante Fast Blue B. Ele é um reagente sensivel, que permite deteç̧ão de 10-50 ng de canabinóides, contrastando com a sensibilidade de outros reagentes, que fica na faixa de $0,5-1 \mu g^{59}$.

$O$ uso de Fast Blue B sofre algumas restrições, essencialmente por causa do risco de conter aminas livres residuais, carcinogênicas. Variações deste corante existem no mercado, e as principais são o Fast Blue RR e o BB.

$O$ Fast Blue RR é menos sensivel que o $B$, mais lento no desenvolvimento da cor, contudo apresenta menos riscos na sua utilização. Já o Fast Blue BB, igualmente mais seguro, é superior em sensibilidade e desenvolve cores mais evidentes, porém gasta mais tempo para desenvolvê-las completamente. Sua estabilidade em solução aquosa é menor,apenas algumas horas, o que impõe preparo recente.

Várias substâncias que desenvolvem cor com Fast Blue $B$ não 0 fazem com 0 $B B$, sendo portanto este último mais seletivo ${ }^{63}$. A questão da diferença de sensibilidade entre os sais, levantada por alguns autores, não foi confirmada por MEATHERALL $e$ GARRIOTT ${ }^{98}$, que explicam para esta variação a diferença de solubilidade entre os sais. O Fast Blue B e o RR se dissolvem mais lentamente em água, e dão cor amarelada ao 
fundo da placa. Contudo, todos os corantes deste grupo, quando aplicados em excesso desenvolvem cor de fundo inicialmente amarela, que escurece por ação da luz ${ }^{96}$. O Fast Blue BB revela igualmente em concentrações variando de $0,05-0,3 \%$, sendo que acima de $0,3 \%$ o corante confere à placa uma cor de fundo amarelada ${ }^{98}$.

VINSON e cols ${ }^{135}$ estudaram a aplicação de outros corantes alternativos ao Fast Blue $\mathrm{BB}$, porém nenhum apresentou melhores resultados que ele.

As placas de CCDAE reveladas com Fast Blue BB são estáveis por vários meses, se guardadas no freezer e cobertas com folhas de alumínio 135,98. Com o tempo, a mancha de $\mathrm{THCCOOH}$ enfraquece e o fundo branco da placa torna-se bege. Neste caso, não adianta reaplicar o corante porque as bandas de $\mathrm{THCCOOH}$ não reaparecerão ${ }^{98}$.

Em relação à basicidade, alguns autores recomendam a adição de $\mathrm{NaOH}$ à solução aquosa de Fast Blue, para que se obtenha desenvolvimento mais rápido da cor dos canabinóides ${ }^{78,64,12}$. Entretanto, segundo MAUNDER ${ }^{96}$, com o uso de $\mathrm{NaOH}$, ocorre uma difusão nas manchas obtidas, devido ao excesso de umidade na placa. Este problema pode ser contornado com a aplicação da base após o desenvolvimento do cromatograma e antes da aplicação do cromógeno.

Mesmo assim, a utilização de $\mathrm{NaOH}$ e $\mathrm{NH}_{4} \mathrm{OH}$ desta maneira não se mostrou muito efetiva. Entre outras bases estudadas, a dietilamina, aplicada antes do desenvolvimento da placa, altera drasticamente o cromatograma e, dependendo das condições analíticas, pode-se não separar $0 \mathrm{THCCOOH}$ do material endógeno coextraído. Juntar dietilamina com Fast Blue BB produz um precipitado, talvez por autoquelação do corante, tornando-o inoperante, com fraco desenvolvimento da cor. Contudo, sua aplicação após o desenvolvimento da placa e antes do cromógeno mostrou bons resultados. A trietilamina funciona tão bem quanto a dietilamina, porém confere uma cor de fundo bege à placa98.

Dietilamina tem sido a base preferida, porque tem baixo ponto de ebulição, permitindo sua aplicação como líquido e a difusão no suporte de CCD como vapor. Além disso, ela não é cara, e seu uso é menos questionado do que o da maioria das aminas, quanto ao potencial carcinogênico.

A dietilamina é considerada reagente fixador e clareador. Ela aumenta a fixação do corante nos sítios ácidos da sílica gel, conduzindo a cores mais evidentes. Quando aplicada antes e após o Fast Blue BB, ela clareia a cor de fundo, produzindo realce das bandas obtidas.

A adição prévia de dietilamina acelera o tempo de desenvolvimento da cor com Fast Blue $\mathrm{BB}^{98,96}$ e aumenta em cerca de 5 vezes sua sensibilidade. A aplicação posterior não é tão eficaz ${ }^{98}$. 
MAUNDER ${ }^{96}$, trabalhando com tolueno como fase móvel, verificou que o desenvolvimento da cor de canabinóides naturais é melhor antes da total evaporação do solvente .Presumivelmente, porque as moléculas do solvente residual permanecem ligadas aos sítios ativos do suporte e permitem uma competição mais efetiva entre o complexo corante-canabinóide e as moléculas de água da sílica gel hidrofilica. Em condições predominantemente aquosas, o complexo corante pode ser precipitado da solução, em vez de ser adsorvido, e isto leva às diferenças de cor observadas. Quanto mais hidrofóbico o solvente, mais intenso o desenvolvimento de cor. Para 0 autor, 0 tempo ideal para a secagem das placas é de 5 minutos, a temperatura ambiente de $20^{\circ} \mathrm{C}$. A placa foi considerada seca quando o aspecto translúcido desapareceu. Nenhum outro autor comentou esta questão.

Logo após secar, aplica-se a dietilamina e, em seguida, O Fast Blue BB. A placa deve secar naturalmente ao ar, a temperatura ambiente e, de preferência, no escuro ${ }^{96}$.

Alguns autores preconizam o uso de vapores de $\mathrm{HCl}$ para observar a mudança de coloração da mancha previamente revelada, de rosa para púrpura47,131. Contudo, este procedimento não é tão bom quando se pretende preservar os cromatogramas por longo tempo ${ }^{96}$.

MEATHERALL 98 observou que a placa de CCDAE precisa ser desenvolvida até 2 horas após a aplicação do resíduo e revelada até 2 horas após o desenvolvimento. Se estes prazos forem excedidos, a intensidade da cor será menor. Parece que o THCCOOH interage com a sílica gel ou com ligantes da placa, produzindo um complexo ou um produto de fundo que não revela com Fast Blue. E este mecanismo, por certo, não envolve a descarboxilação do $\mathrm{THCCOOH}$, já que deste modo seria produzido o $\Delta^{9}-T_{H C}$, e este apareceria na placa ${ }^{77}$.

Outro problema que pode afetar a visualização das bandas de $\mathrm{THCCOOH}$ é $\mathrm{O}$ efeito da matrix urinária. FREDERICK e cols ${ }^{47}$ utilizando como solvente extrator a mistura hexano:acetato de etila, relatam que urinas adicionadas de quantidade idênticas de THCCOOH não mostraram variação na intensidade da banda se fossem replicatas de um mesmo indivíduo. Se a mesma quantidade de $\mathrm{THCCOOH}$ fosse adicionada à urina de pessoas diferentes, as intensidades das manchas variavam entre si. Contudo, Meatherall ${ }^{98}$ não observou este efeito ao utilizar apenas hexano como solvente extrator, e atribuiu estas diferenças ao sistema solvente empregado pelos autores. Ele também relata que não ocorreram diferenças de hRf entre 0 padrão e $\circ \mathrm{THCCOOH}$ adicionado, revelando que nenhuma substância co-extraída por hexano interfereria na interpretaçäo do cromatograma.

Solventes tipo éter, clorofórmio, diclorometano e acetato de etila, fornecem resíduos que, quando aplicados no cromatograma, apresentam cor de fundo escura, 
dificultando ou impossibilitando a visualização das bandas de THCCOOH${ }^{98,78}$. KANTER ${ }^{78}$ observou que $80 \mathrm{ng}$ de $\mathrm{THCCOOH}$ adicionados diretamente na placa são visualmente semelhantes a $250 \mathrm{ng}$ adicionados ao resíduo do extrato etéreo da urina aplicado na placa, evidenciando a interferência dos compostos endógenos co-extraídos pelo éter.

\subsubsection{Interferentes}

A pesquisa de interferentes endógenos e exógenos na análise de canabinóides por $C C D$ foi investigada por alguns autores. KAISTHA e TADRUS77 pesquisaram substâncias endógenas e outros produtos de biotransformação do THC. KING ${ }^{86}$ analisou urinas de usuários de 100 diferentes medicamentos com seus repectivos produtos de metabolismo. HUGHES ${ }^{63}$ pesquisou a interferência de 71 substâncias químicas extraídas de plantas e 15 óleos essenciais. FREDERICK ${ }^{47}$ analisou urinas contendo 59 diferentes fármacos. MEATHERALL 98 testou adicionados de 118 fármacos e produtos de biotransformação em sua metodologia para CCDAE. Em nenhum destes trabalhos foi observada mancha de igual coloração e hRf do padrão de $\mathrm{THCCOOH}$, exceto para 0 $\Delta^{8}-\mathrm{THCCOOH}$, fato observado em 2 trabalhos ${ }^{98,63}$, o que sugere este produto como padrão substituto.

Manchas de cores diferentes não devem ser consideradas ${ }^{81}$. MEATHERALL ${ }^{98}$ relata que a cor rosa-avermelhado é bem caracteristica dos canabinóides. Portanto, a presença de manchas nesta tonalidade, porém em hRf diferente do padrão de $\mathrm{THCCOOH}$, provavelmente se refere a outros canabinóides encontrados na urina, e não devem ser consideradas. 


\subsubsection{Identificação por técnicas imunológicas}

Métodos imunológicos são utilizados na análise de fármacos por sua rapidez, simplicidade e relativo baixo custo. $\mathrm{Na}$ última década, tem sido observado o desenvolvimento e o refinamento de novos reagentes e sistemas para imunoensaios.

A possibilidade de automação fez com que os imunoensaios fossem amplamente empregados na triagem de fluidos biológicos para detecção de usuários de drogas de abuso. Os mais utilizados são: o radioimunoensaio (RIA), o enzimoimunoensaio (EIA) e, mais recentemente, o imunoensaio de fluorescência polarizada (FPIA $)^{138,98}$.

Existe uma tendência de substituir os ensaios em fase líquida com radioisótopos , pelos simples e rápidos ensaios homogêneos que não envolvem o uso de radioatividade. A engenharia genética trouxe ao mercado os anticorpos monoclonais, com especificidades mais definidas, e mais fáceis de serem produzidos para suprimento continuo ${ }^{54}$. Por isso, VINSON e cols ${ }^{135}$ relatam que em 1983 vários milhões de testes de urina foram realizados nos Estados Unidos para determinar se indivíduos faziam uso de Cannabis. A grande maioria através de imunoensaios.

A filosofia que rege a utilização dos ensaios imunológicos na fase de triagem visa separar as urinas negativas das prováveis positivas para as substâncias pesquisadas. 0 termo "cutoff" tem sido empregado aqui como um valor limite de concentração, para que se possa classificar uma amostra como positiva ou negativa.

Este valor limite pode ser variável, dependendo do objetivo da análise toxicológica. Para estabelecer o "cutoff" na identificação de usuários, é necessário conhecimento da farmacocinética da Cannabis e dos niveis de produtos de biotransformação urinários presentes em diferentes padrões de uso da droga (uso ocasional, moderado ou freqüente) 43,19 .

A maioria dos reagentes (Kits) para imunoensaios que se destinam à detecção de usuários de Cannabis visam o principal produto de biotransformação, que é o THCCOOH. Temos que pensar, entretanto, que pelo menos 35 diferentes produtos de biotransformação do $\Delta^{9}$-THC, 22 do Canabidiol (CBD)e 22 do Canabinol (CBN) são conhecidos no momento e estão presentes na urina depois do uso de Cannabis77. As substâncias demonstraram possuir reatividade cruzada nos métodos imunológicos em padrões diferentes para cada método.

Variações individuais no metabolismo, tanto quanto diferença de reatividade dos anticorpos entre os métodos, podem conduzir a resultados diferentes para uma mesma amostra, ainda que na padronização dos métodos tenha sido usado o mesmo 
calibrador $143,74,39$. Portanto, a análise por imunoensaios não é específica para um produto de biotransformação e, sim, para um grupo estruturalmente relacionado.

Além disso, amostras de urina podem conter outras substâncias diferentes das que estão sendo testadas, tanto de origem endógena quanto exógena. Algumas destas substâncias podem interferir na reação antígeno-anticorpo, gerando resultados falsospositivos ou falsos-negativos. Na tabela 6 estão listados alguns trabalhos onde foram avaliados os índices de resultados não-confirmados.

Muito cuidado é preciso tomar na avaliação desses resultados já que estas confirmações são feitas por técnicas cromatográficas, especificas para $0 \mathrm{THCCOOH}$. Outro ponto a ser observado é o valor de "cutoff" estabelecido para o ensaio imunológico, muitas vezes superior à sensibilidade do método cromatográfico ${ }^{48}$.

Tabela 6. Indices de resultados obtidos por alguns imunoensaios e não confimados por outras técnicas.

\begin{tabular}{|c|c|c|c|c|}
\hline \multirow[t]{2}{*}{ Imunoensaio } & \multicolumn{2}{|c|}{ Não Confirmados } & \multirow{2}{*}{$\begin{array}{l}\text { Método de } \\
\text { confirmação }\end{array}$} & \multirow[t]{2}{*}{ Ref. } \\
\hline & Pos $\%$ & Neg $\%$ & & \\
\hline RIA ("cutoff" 10ng/ml) & 10 & 3 & CG/MS & 114 \\
\hline RIA ("cutoff" 10ng/ml) & 2,5 & - & CG/MS & 106 \\
\hline EMITß & 4 & - & CG/MS & 1 \\
\hline RIA & 0,3 & - & & \\
\hline EMIT@ ("cutoff" 100ng/ml) & 3,1 & $2-4$ & CG/MS - CCD & 122 \\
\hline EMIT\& ("cutoff" 20ng/ml) & 5 & - & CCDAE & 135 \\
\hline EMIT® ("cutoff" 75ng/ml) & 8 & 2 & CLAE - CCDAE & 64 \\
\hline EMIT® ("cutoff" 20ng/ml) & $2-3$ & - & CG/MS & 47 \\
\hline EMIT® ("cutoff" 20ng/ml) & $<3$ & - & CG/MS & 131 \\
\hline EMIT\& ("cutoff" 20ng/ml) & 1 & - & CG/MS & 44 \\
\hline EMIT\& ("cutoff" 20ng/ml) & 1,9 & - & CLAE & 83 \\
\hline TDX\& ("cutoff" 25ng/ml) & - & - & & \\
\hline
\end{tabular}


Em estudo realizado pela American Association of Clinical Chemistry (AACC), quarenta e sete laboratórios participaram de um esquema de controle externo de qualidade. Após triagem imunológica, os laboratórios usavam na fase de confirmação diferentes técnicas cromatográficas: $30 \%$ dos laboratórios utilizavam CG/MS, $30 \%$ usavam CG com coluna capilar e outros 30\%, CCD. Observaram que quando o "cutoff" utilizado na triagem era de $50 \mathrm{ng} / \mathrm{ml}$, o percentual de precisão dos resultados era de $100 \%$ para canabinóides. Não ocorreram falsos positivos $e$, sim, falsos negativos na faixa de $4,6 \% 48,49$.

Vários autores comparam as técnicas imunológicas entre si e com métodos cromatográficos, trazendo informações importantes para a interpretação de resultados.

MOODY e cols 103 , trabalhando com extratos metanólicos de sangue analisados por RIA e CG/MS, comprovaram que as concentrações de $\mathrm{THCCOOH}$ encontradas com RIA eram três vezes maiores que as obtidas com CG/MS, devido à reatividade cruzada do anticorpo com outros canabinóides presentes na amostra.

ABERCROMBIE e JEWELL' ${ }^{1}$, analisando por RIA 481 amostras classificadas como negativas por EMIT® ("cutoff" $100 \mathrm{ng} / \mathrm{ml}$ ), encontraram 22 positivas $(4,6 \%)$. Ao analisálas por CG/MS, 16 possuíam valores de THCCOOH em torno de $20 \mathrm{ng} / \mathrm{ml}$, e 6 abaixo deste valor. Os autores relatam $91 \%$ de concordância entre os resultados do EMIT e do RIA.

BUDGETT e cols ${ }^{17}$ compararam os resultados obtidos da análise de 142 amostras de urina através de RIA (Abuscreen(8)) e de FPIA (TDX(8) com CG/MS. Apenas 10 amostras não revelaram resultados coincidentes, e estas, quando analisadas por $\mathrm{CG} / \mathrm{MS}$, revelaram concentrações de THCCOOH entre $15-47 \mathrm{ng} / \mathrm{ml}$. Destas dez, 9 foram positivas pelo RIA, mostrando um percentual maior de reatividade cruzada.

KARISSON e STROM ${ }^{83}$ usaram CLAE para confrontar os resultados obtidos com TDX® e EMIT®. Utilizando praticamente o mesmo valor de "cutoff" para todas as técnicas, os autores construíram curvas de calibração para TDX® e EMIT®. Estudos de precisão revelaram coeficientes de variação bem menores no TDX® com boa estabilidade de calibração. Já no EMIT® existe a necessidade de se empregarem calibradores em cada corrida analítica, pelo menos uma vez ao dia. Para concentrações de $20 \mathrm{ng} / \mathrm{ml}$, foram observadas grandes flutuações no coeficiente de variação intra-série, indicando que a concentração de "cutoff" talvez esteja mais perto da sensibilidade do método no EMIT® do que no TDX $\otimes$. A seguir, os autores analisaram por TDX $($ ("cutoff" $25 \mathrm{ng} / \mathrm{ml}$ ) e por EMIT囚 ("cutoff" $20 \mathrm{ng} / \mathrm{ml}$ ) 63 amostras com concentrações de THCCOOH na faixa de $20-873 \mathrm{ng} / \mathrm{ml}$ avaliadas em CLAE. Todas foram classificadas como positivas, com $100 \%$ de concordância entre os dois métodos imunológicos. 
Novamente, outras 263 amostras foram analisadas. Destas, 203 eram negativas em ambos os métodos e 33 eram positivas. Das 27 amostras com resultados discrepantes, 15 deram resultado com erro de leitura no TDX®, devido ao alto valor de "background" das amostras. 12 amostras foram negativas no TDX e positivas no EMIT\&. Destas, 7 amostras foram positivas no CLAE com valores de THCCOOH menores ou iguais a $10 \mathrm{ng} / \mathrm{ml}$, o que justifica a classificação feita pelo TDX® como sendo "negativas*" (próximas ao valor de "cutoff"). As outras 5, quando analisadas segunda vez por EMITQ, eram negativas.

Apesar do TDX® ter um custo maior e gastar 20 min para ler um carrossel com 20 amostras, enquanto o EMITه analisa 25 amostras em 8 minutos, sua excelente precisão e estabilidade de calibração se constituem em vantagens sobre 0 EMIT\& 83 .

WELLS e BARNHELL 143, utilizando um mesmo valor de "cutoff" (100 ng/ml) compararam os resultados obtidos por 5 diferentes imunoensaios na análise de canabinóides. Três técnicas de radioimunoensaio e 2 técnicas não radioativas (EMIT® e TDXQ) foram utilizadas neste estudo. Em 1988, o National Institute of Drug Abuse (NIDA) dos Estados Unidos estabeleceu o "cutoff'de $100 \mathrm{ng} / \mathrm{ml}$ para os testes relacionados a programas em empresas: por isso este foi o valor de "cutoff" escolhido pelos autores. Para as 26 amostras submetidas a análise, os métodos não radioativos classificaram apenas 3 como positivas, enquanto os outros classificaram 5 (Abuscreen®) e 7 (DPC®) e Immunalysis $(\otimes)$.

As variaçōes individuais entre usuários na metabolização do THC e as diferentes reatividades dos anticorpos entre os métodos conduziu a estes resultados discrepantes, mesmo utilizando-se um único valor de "cutoff" e o mesmo calibrador. Os autores citam que, através da comparação dos resultados obtidos por imunoensaios com os obtidos por cromatografia gasosa, foi observado que o $\mathrm{THCCOOH}$ corresponde apenas a $31 \%$ dos canabinóides totais detectados por RIA, enquanto para O EMIT® este percentual é maior, $48,9 \%$, mostrando menos reatividade cruzada.

ELSOHLY e cols $^{39}$ relataram maior especificidade do anticorpo utilizado no TDX do que os do EMIT(8) e RIA, com indice menor de reatividade cruzada entre os canabinóides.

FREDERICK e cols 47 utilizaram CCD para confirmar resultados do EMIT®; $17 \%$ das amostras positivas no EMIT® não foram confirmadas por CCD. Estas amostras, quando analisadas por CG/MS, revelaram ser realmente negativas ou que possuíam concentrações de $\mathrm{THCCOOH}$ inferiores a $20 \mathrm{ng} / \mathrm{ml}$ (limite de sensibilidade do método de CCD empregado ). Duas amostras negativas no EMIT® foram positivas na CCD, e 
confirmadas por CG/MS ( $<20 \mathrm{ng} / \mathrm{ml}$ ). Esta variação de sensibilidade na CCD pode estar ligada a fatores desconhecidos da matrix urinária.

KOGAN e cols ${ }^{90}$ também recomendam o uso de CCD para confirmar os resultados do EMIT®, principalmente em análises com objetivo clínico. FOLTZ e SUNSHINE 44 compararam os resultados obtidos por CCD, EMIT® e CG/MS para um grupo de amostras. Estes resultados foram transcritos para as tabelas 7 e 8 .

Tabela 7. Resultados obtidos por FOLTZ \& SUNSHINE 44 na análise de amostras de unina por CCD e CGMS visando a deteç̧ăo de THCCOOH.

\begin{tabular}{llc}
\hline Técnica & concentração & número de amostras \\
\hline CG/MS & $\geq 20 \mathrm{ng} / \mathrm{m}^{\star *}$ & 194 \\
CCD & $\geq 20 \mathrm{ng} / \mathrm{m}^{* \star}$ & 178 \\
CG/MS & $<20 \mathrm{ng} / \mathrm{ml}^{*}$ & 347 \\
CCD & $<20 \mathrm{ng} /\left.\mathrm{m}\right|^{*}$ & 16 \\
& \\
* valor limite para classificar a amostra como negativa \\
** valor limite para classificar a amostra como positiva. \\
$\mathrm{n}=541$
\end{tabular}

Como se pode ver na tabela 7, das amostras positivas por CG/MS $16(9 \%)$ foram negativas por $C C D$ (sensibilidade $=20 \mathrm{ng} / \mathrm{ml}$ ) e continham em média $36,4 \mathrm{ng} / \mathrm{ml}$ de THCCOOH quando analisadas por CG/MS. Este índice de falsos negativos é, entretanto, menos problemático do que seria um índice de falso positivo, neste caso, zero para CCD. Contudo, a CCD confirmou como positivas 11 amostras que continham entre 5-19 $\mathrm{ng} / \mathrm{ml}$ de $\mathrm{THCCOOH}$ no CG/MS. Esta diferença de sensibilidade na CCD é devida também à natureza subjetiva da interpretação ( comparação visual com adicionados contendo $20 \mathrm{ng} / \mathrm{ml}$ de $\mathrm{THCCOOH}$, utilizando-se $3 \mathrm{ml}$ de amostra). Uma discriminação melhor foi obtida por densitometria.

Por estimativa visual, esta técnica de CCD apresenta $95 \%$ de precisão, sendo possivel detectar $O \mathrm{THCCOOH}$ em amostras com concentraçōes inferiores a $10 \mathrm{ng} / \mathrm{ml}$.

$\mathrm{Na}$ tabela 8, podemos observar a correlação entre os resultados do EMIT® e do CG/MS. O grande indice de falsos negativos (37\%), isto é, amostras negativas no EMITQ e positivas no CG/MS, deve-se à diferença de "cutoff" entre os dois métodos. Foi 
observado apenas um resultado falso positivo no EMITQ. Os resultados da CCD se correlacionam melhor com os do CG/MS do que os resultados do EMIT®. Isto não é uma surpresa, considerando-se que CCD e CG/MS detectam um canabinóide especifico, enquanto no EMIT® outros canabinóides contribuem com o resultado.

Tabela 8. Resultados obtidos por FOLTZ e SUNSHINE44 na análise de amostras de unina por EMIT e CGMS visando a deteç̧ăo de THCCOOH.

\begin{tabular}{llc}
\hline Técnica & concentração & número de amostras \\
\hline CG/MS & $\geq 20 \mathrm{ng} / \mathrm{ml}^{* *}$ & 172 \\
EMIT & $\geq 100 \mathrm{ng} / \mathrm{ml}^{* *}$ & 109 \\
CG/MS & $<20 \mathrm{ng} / \mathrm{ml}{ }^{*}$ & 293 \\
EMIT & $<100 \mathrm{ng} / \mathrm{ml}{ }^{*}$ & 63 \\
\hline
\end{tabular}

\footnotetext{
* valor limite para classificar a amostra como negativa

** valor limite para classificar a amostra como positiva $n=465$
}

A interferência de grupos especificos de substâncias foi estudada. WINEK e cols ${ }^{145}$ estudaram a interferência de extratos de plantas. Outros autores estudaram a interferência de medicamentos $47,131,46$. Nenhum deles relata reatividade cruzada nas concentrações em que foram testados.

O significado legal e as conseqüências econômicas de um resultado positivo para droga de abuso compreensivelmente produzem um incentivo, entre os usuários de drogas ilícitas, para escaparem da deteç̧ão. Para alguns, a adulteração da amostra representa uma opção. Métodos disponiveis para isto são vários e vão desde uma simples diluição da urina até sua substituição pelo conteúdo de uma bola de borracha que, por cateterismo, alcança o frasco coletor.

Adulteração com agentes químicos é um método escolhido por muitos porque requer pouca sofisticação e pode ser facilmente executado num lugar onde não haja observação da coleta.

A introdução de uma amostra adulterada é potencialmente real em qualquer programa de teste de drogas, e o conhecimento do impacto que um adulterante pode ter 
em um sistema analítico é um elemento importante para assegurar a integridade deste sistemas ${ }^{123}$.

Vários trabalhos foram feitos com adição de adulterantes em urinas previamente analisadas e positivas para $\mathrm{THCCOOH}$. Os adulterantes testados são substâncias facilmente disponiveis, como cloreto de sódio, vinagre, sabonete ou sabão líquido,

hipoclorito de sódio, alvejantes, medicamentos ( especialmente colírios ), álcool, água oxigenada, bicarbonato de sódio, etc. 122,16,123,100,112,137,24.

Em relação às técnicas imunológicas, os reagentes para deteç̧ão de canabinóides mostraram ser os mais sensiveis à ação de adulterantes. O FPIA é relativamente resistente a adulterantes em relação à produção de resultados falsos positivos. Adição de adulterantes a urinas negativas teve pouco impacto nos resultados. No entanto, aproximadamente metade dos adulterantes testados causa falsos negativos. Com exceção do hipociorito de sódio, nenhum deles faz isto via degradação de canabinóides ${ }^{123}$.

Nem sempre é fácil distinguir entre uma urina normal e outra adulterada. Alguns autores discutem indicadores de adulteração: $\mathrm{pH}$, cor, turbidez, níveis de creatinina e gravidade específica100,36

LAFOLIE e cols 92 relatam a importância da análise simultânea de creatinina no acompanhamento da abstinência de canabinóides. A figura 6 mostra a dosagem de canabinóides e de creatinina para um usuário pesado durante 100 dias de abstinência. Se os resultados não forem corrigidos pela creatinina, fica difícil afirmar que não houve reutilização da droga.

MANNO 95 abordou o mesmo aspecto. Como pode ser visto na figura 7 , o aparente aumento na excreção de canabinóides no dia 6 se relaciona com uma amostra mais concentrada, e não com reutilização da droga.

MITCHELL e cols ${ }^{101}$ relatam que filtrar a urina em diferentes tipos de filtros (nylon, PVDF, polisulfona, acetato de celulose) pode provocar resultados falsos negativos em amostras com 50-100ng/ml de canabinóides. A centrifugação seria mais recomendada, mas é preciso lembrar que os canabinóides se concentram mais nos sedimentos da urina do que na fração aquosa 45 . 

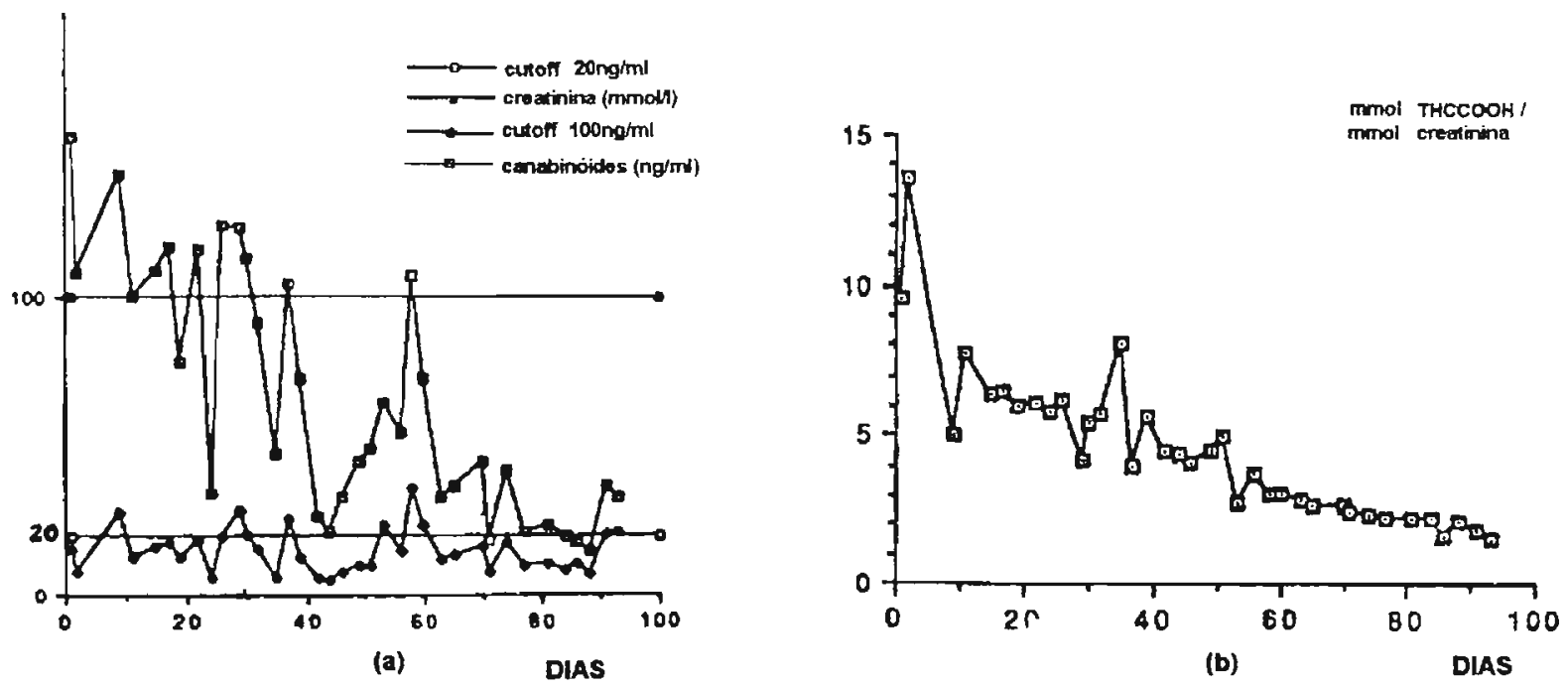

Figura 6. Concentrações uninárias de $\mathrm{THCCOOH}$ ( $\mathrm{ng} / \mathrm{ml}$ de canabinóides) e creatinina durante 93 dias de abstinéncia de um usuário crônico (a). A razão THCCOOH/creatinina revela um declínio constante (b) 62 .

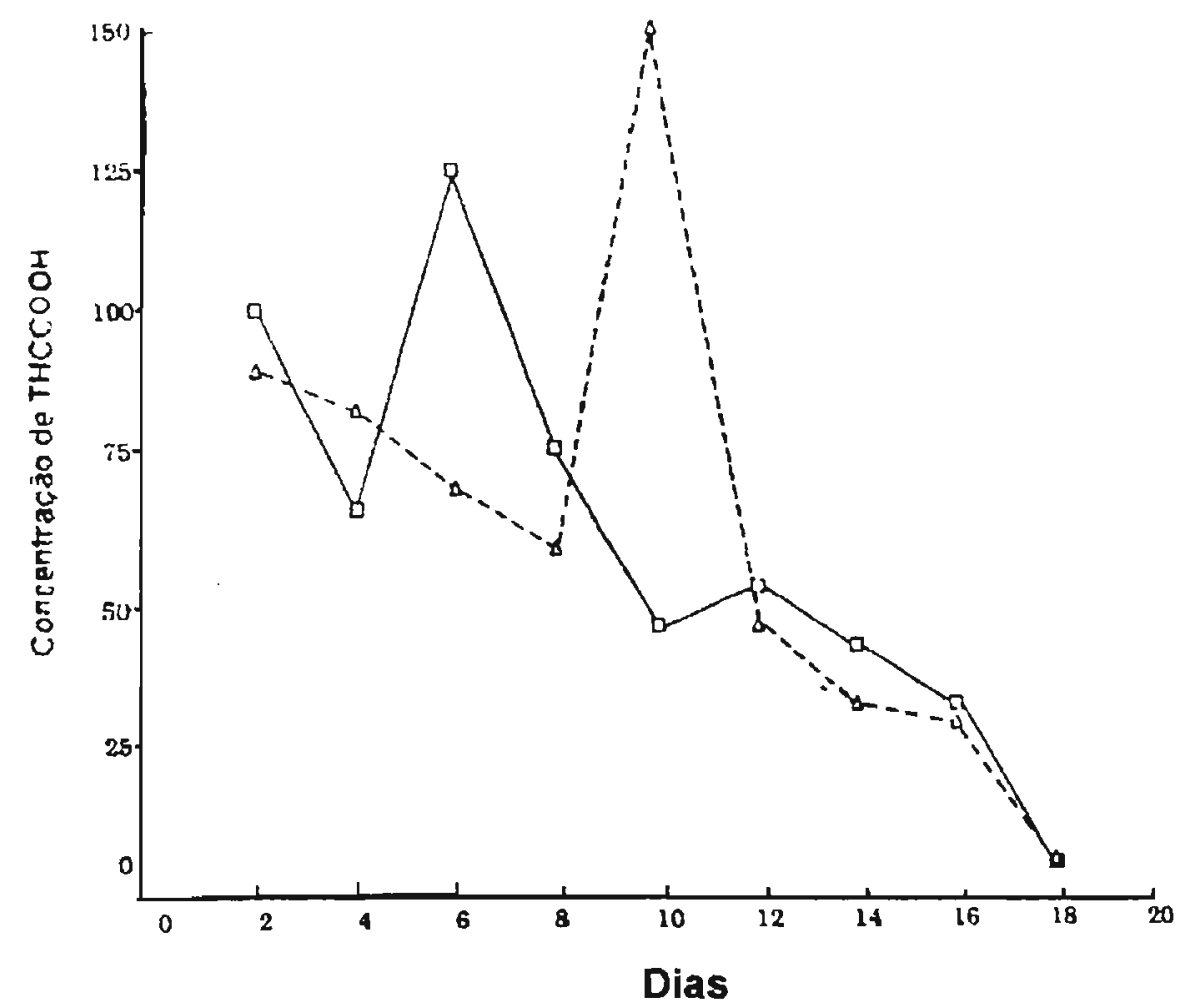

Figura 7. Niveis de $\mathrm{THCCOOH}$ urinário de amostras colhidas em dias alternados após o último uso de Cannabis. $\square-T H C C O O H$ ng/ml. $\Delta-n g$ THCCOOH/mg creatinina 60. 
2.2.6 Imunoensaio de fluorescência polarizada

O imunoensaio de fluorescência polarizada surgiu a partir do interesse em se desenvolverem imunoensaios que não utilizassem isótopos. Os marcadores nãoisotópicos mais utilizados são as enzimas e as substâncias fluorescentes. As vantagens principais de se desenvolverem ensaios fluorescentes são: a relativa facilidade de se introduzirem grupos fluorescentes não-tóxicos tanto na molécula do analito quanto na do anticorpo; a sensibilidade com que estes grupos fluorescentes podem ser detectados nos espectrofluorímetros disponíveis; e a possibilidade de desenvolvimento de ensaios homogêneos, que são mais fáceis de serem executados e automatizados.

Uma das substâncias fluorescentes mais utilizadas como marcador é a fluoresceina ${ }^{87}$. Ela é geralmente ligada ao antígeno, sendo o produto desta ligação chamado de traçador (F-Ag).

Existem vários tipos de ensaios fluorescentes que monitoram a fluorescência em função da reação antígeno-anticorpo. Se a diferença espectroscópica entre traçador ligado (complexo F-Ag-Ac) e livre (F-Ag) for suficiente, um ensaio homogêneo pode ser feito.

A maioria dos fluoroimunoensaios (FIA) homogêneos são do tipo competitivo, em que a ligação com o anticorpo causa alteração na propriedade fluorescente do antígeno marcado ${ }^{56}$. Baseados nesta alteração, existem métodos diferentes que avaliam aumento ou diminuição da intensidade da fluorescência e, mais recentemente, a variação na polarização da fluorescência 87 .

Os princípios fundamentais da polarização da fluorescência foram desenvolvidos por PERRIN,F. em uma série de artigos começando em 1926. WEBER,G. foi o primeiro a aplicar a técnica a sistemas biológicos em 1953, após desenvolver o fluorímetro requerido para sua aplicação ${ }^{73}$.

Em 1961, DANDLIKER e FEIGEN56 descreveram sua utilização no estudo da reação antígeno-anticorpo, determinando, através da polarização da fluorescência, dois importantes parâmetros: a constante de equilíbrio e a capacidade combinante característica da reação antígeno -anticorpo ${ }^{30,116}$

Em 1973, DANDLIKER apresentou, pela primeira vez, o método de imunoensaio de fluorescência polarizada (FPIA ${ }^{73}$.

Para entendermos melhor os princípios que regem essa técnica, é importante recordar de modo sucinto algumas caraterísticas associadas aos fenômenos de emissão de fluorescência : 
a) A energia absorvida nos processos de transição eletrônica é liberada quando os elétrons retornam ao estado fundamental. A fluorescência é um tipo característico de emissão dos estados excitados, onde a conversão da luz absorvida por uma molécula em energia emitida é rápida;

b) A determinação da quantidade de energia liberada neste processo pode ser determinada com auxílio de um fotomultiplicador ;

c) Toda a energia absorvida na excitação é liberada num curto intervalo de tempo, na faixa de nano-segundos, chamado de tempo de vida do estado excitado;

d) A fluorescência emitida pode ser polarizada. Enquanto a luz ordinária consiste em uma mistura de ondas vibrando em todas as direções perpendicularmente à sua linha de propagação, a luz polarizada é aquela em que a vibração do campo elétrico ou magnético é confinada a um plano. Podemos obtè-la com auxilio de alguns cristais. Estes cristais têm a propriedade de refratar a luz em duas diferentes direções: raio ordinário e raio extraordinário - ambos polarizados em direções perpendiculares um em relação ao outro.

Estudos com luz polarizada revelaram princípios importantes utilizados nessa técnica. Utilizando-se a fluoresceina, cujo $\lambda$ de excitação é $485 \mathrm{~nm}$ e $\circ \lambda$ de emissão é $520 \mathrm{~nm}$, e levando em conta que nestas circunstâncias estuda-se apenas a transição para o primeiro estado excitado $\left(S_{0} \rightarrow S_{1}\right)$, observou-se que um máximo de emissão ocorre quando o momento de dipolo da emissão for paralelo ao vetor da luz polarizada incidente,e um mínimo de emissão quando for perpendicular. Portanto, se a observação da emissão for feita paralelamente ao vetor da luz incidente, um máximo de emissão estará sendo observado. Isto é possivel se a emissão for também polarizada. Se a observação for perpendicular, o valor da emissão será mínimo. Teoricamente, os valores de polarização da emissão variam entre $+1 / 2$ a $-1 / 373,9$.

$\mathrm{Na}$ prática, são colocados dois polarizadores: um para polarizar a luz incidente e outro para polarizar a luz emitida (fluorescência). Alguns aparelhos trabalham com um polarizador móvel, ou seja, um cristal líquido capaz de rodar o plano da luz polarizada, quer no primeiro ou segundo polarizador. Isto é feito para poder observar os valores máximos e mínimos de fluorescência, se os polarizadores forem paralelos entre si ou perpendiculares entre $s i$, respectivamente. Esta estratégia permite a avaliação da polarização relativa, que nos favorece analíticamente, por não depender da intensidade da fluorescência, nem da concentração do fluoróforo'117.

A figura 8 mostra um esquema de sistema ótico utilizado para avaliar a polarização da fluorescência. 


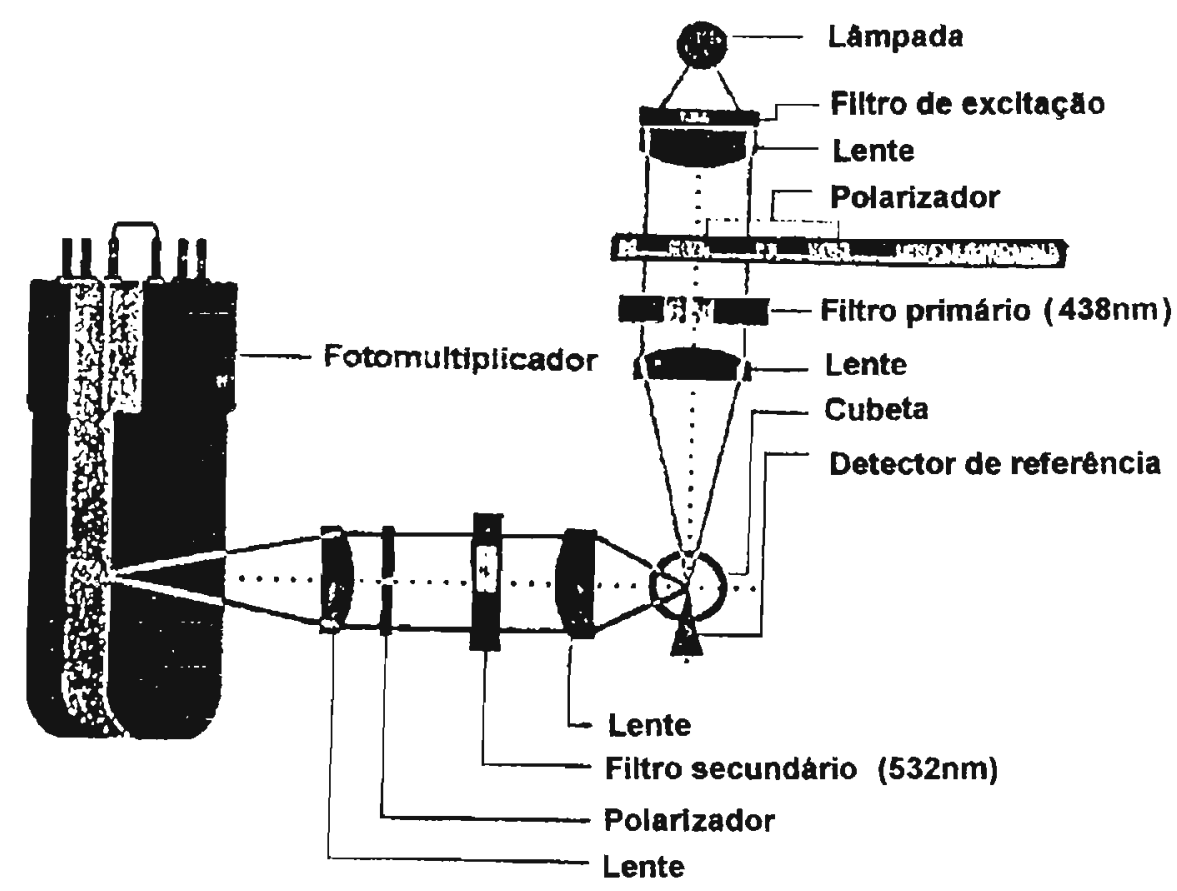

Figura 8. Esquema de um sistema ótico utilizado para medir a polarização da fluorescência (Vitalab Eclair()).

A avaliação da polarização relativa é feita pela seguinte fórmula:

$$
\operatorname{Pr}=\text { Ivv- Ihv / Ivv + Ihv }
$$

Ivv seria a intensidade da fluorescência avaliada com os dois polarizadores em pararelo, enquanto que para lhv os dois polarizadores estariam perpendiculares entre si, ou seja, em um deles houve a rotação do plano da luz polarizada.

$\mathrm{Na}$ verdade, apenas $10 \%$ da intensidade de fluorescência estão sendo avaliados. Esta perda é compensada pelo fato de a polarização ser menos sensivel aos interferentes que comumente afetam os FIA homogêneos. A sensibilidade aqui é definida como a concentração de fluoresceína, que pode ser distinguida do tampão com $95 \%$ de confiabilidade ${ }^{117}$. 
Para uma pequena molécula, como, por exemplo, um antígeno marcado (antígeno ligado a fluoresceína), livre em solução, desenvolvendo movimento Browniano, observou-se que $\operatorname{Pr}$ é próximo de zero. Isto porque o tempo que a molécula gasta para "rodar" é menor do que o tempo de vida do estado excitado, isto é, o tempo necessário para emissão da energia absorvida. Neste caso, a avaliação com uso de polarizadores é apenas parcial9.

Por outro lado, a molécula grande, por exemplo, um complexo anticorpo antígeno marcado, gira mais lentamente, retendo mais sua orientação original, tendo um valor de $\operatorname{Pr}$ maior do que zero ${ }^{87,30}$. Assim, o tempo de vida do estado excitado é tempo fixo, o que varia é o tempo de rotação da molécula, diretamente relacionado à polarização.

Na figura 9 veja-se um esquema do princípio da técnica de FPIA.
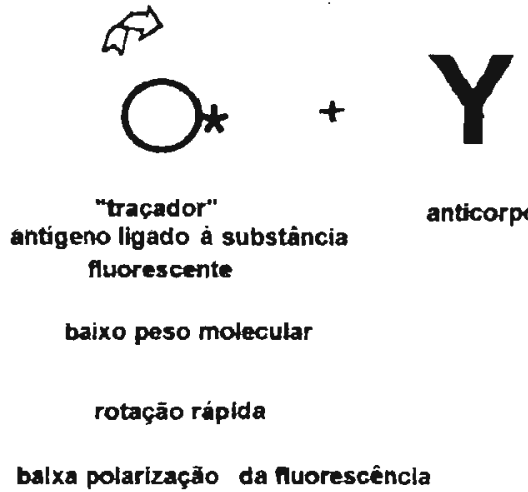

anticorpo

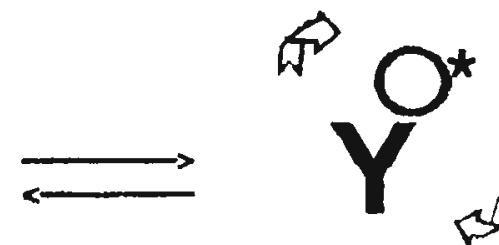

complexo antigeno-traçador

alto peso molecular

rotação lenta

alta polarização da fluorescéncia

Figura 9. Esquema do principio da técnica do imunoensaio de fluorescéncia polarizada.

Não só o tamanho da molécula provoca variações na polarização. Fatores como temperatura e viscosidade do meio são importantes, e pequenas variações nestes parâmetros afetam grandemente a polarização ${ }^{73}$. Neste ponto, podemos avaliar como se interpreta a polarização de fluorescência na ligação antígeno-anticorpo.

A figura 10 mostra um esquema do princípio de imunoensaio competitivo, associado ao princípio da polarização de fluorescência. 

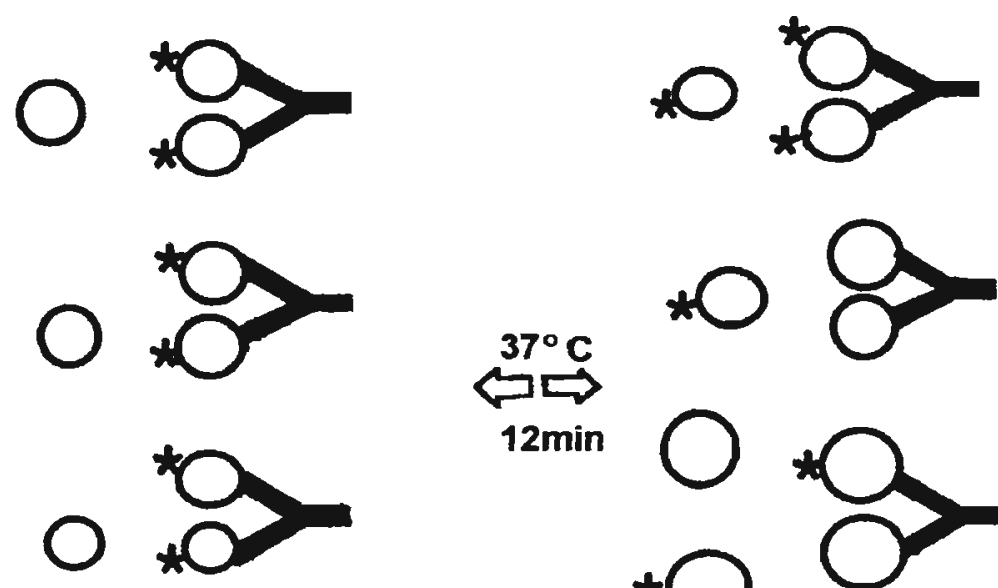

$12 \mathrm{~min}$
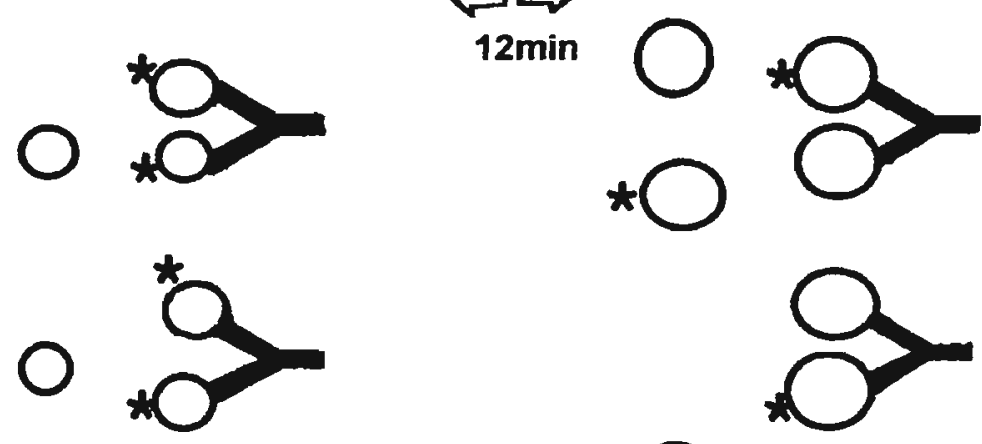

amostra

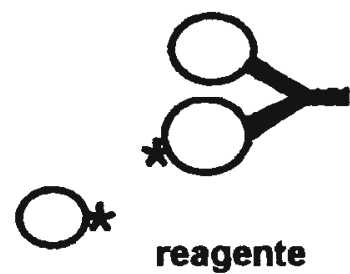

Figura10. Mecanismo competitivo do imunoensaio de fluorescência polanizada.

Quando uma amostra, sem antígeno, é colocada em contato com o reagente [ Ac-Ag-F ], observamos um alto valor de polarização. Todavia, se na amostra existirem antígenos, estes vão competir pelos sítios de ligação do anticorpo, e antígenos marcados ficarão livres em solução, gerando uma diminuição na polarização.

As mudanças nos valores de Pr são geralmente pequenas, em torno de 0,1 , e um controle rígido na temperatura é necessário de modo que Pr possa ser avaliado com uso de três decimais ${ }^{87}$. Para facilitar, podemos então usar o termo milipolarização, e trabalhar com números inteiros.

A desvantagem inicial que esta técnica possuía, no sentido de limitar sua utilização à moléculas pequenas, tornou-se em vantagem para a análise de fármacos em meio biológico 73 . 
O gráfico de calibração obtido no FPIA tem dois aspectos a serem considerados: sua inclinação é negativa, porque o analito não-marcado compete com o traçador ( analito marcado ) pelos sitios do anticorpo, gerando queda na polarização e, conseqüentemente, a polarização é inversamente proporcional à concentração; outro aspecto é que a relação não-linear convexa é típica dos ensaios competitivos, e é obtida entre a polarização relativa de fluorescência e a concentração do analito. Esta é outra grande vantagem desta técnica; ela fornece resultado direto em termos de concentração.

A figura 11 mostra um gráfico típico de calibração obtido no FPIA.

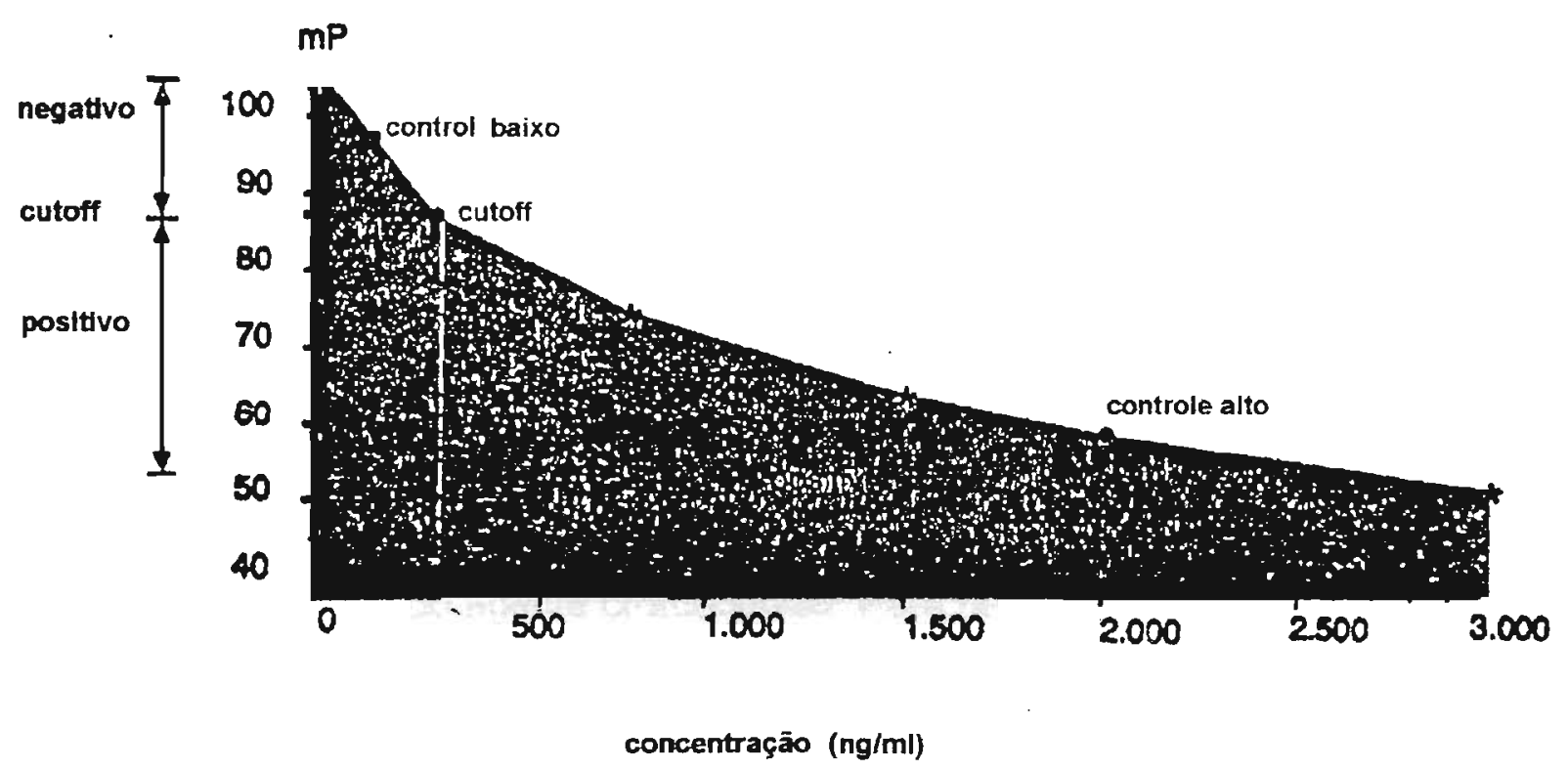

Figura 11. Gráfico típico de calibração obtido em um imunoensaio de fluorescéncia polarizada (Vitalab Eclair (®)).

O considerável sinal de fundo das amostras biológicas limita a sensibilidade prática desta técnica. Isto se deve à fluorescência de compostos endógenos, ou de outras substâncias existentes na amostra ${ }^{134}$. Moléculas maiores, como as moléculas de proteínas, podem causar espalhamento da luz ${ }^{87}$. É necessário, então, proceder à análise de um branco que, no caso, seria a própria amostra com o tampão, sem adição de reagente, para avaliação e desconto desta fluorescência intrínseca. Reações cruzadas são passíveis de acontecer mas se relacionam mais às caracteristicas do anticorpo ${ }^{30}$. 
2.2.7 Outras técnicas analíticas utilizadas na análise de canabinóides em fluidos biológicos.

Um axioma aceito na identificação qualitativa em toxicologia diz que "no mínimo duas técnicas com diferentes princípios analíticos precisam ser usadas para identificar a presença de um composto"47. Assim, usando imunoensaios na fase de triagem, convém seja aplicado um método cromatográfico na fase de confirmação.

Alguns fatores precisam ser considerados ao se selecionar um método de análise para a fase de confirmação. Um deles é a sensibilidade. Se o objetivo é confirmar resultados oriundos de um imunoensaio, bastaria o método ser capaz de detectar 20 $\mathrm{ng} / \mathrm{ml}$ de $\mathrm{THCCOOH}^{45}$. De fato, em 1988, The United States Departament of Health and Human Services (HHS) determinava um "cutoff" de $100 \mathrm{ng} / \mathrm{ml}$ para fase de triagem e $20 \mathrm{ng} / \mathrm{ml}$ para fase de confirmação130. Contudo, em 1990, a NIDA (National Institute of Drug Abuse) estabelecia um "cutoff" de $15 \mathrm{ng} / \mathrm{ml}$ para fase de confirmação44. Sendo assim, para que um método seja selecionado como método de confirmação, é necessário primeiramente que ele possua sensibilidade inferior $15 \mathrm{ng} / \mathrm{ml}$ e boa precisão neste valor de "cutoff".

Vários fatores influenciam a sensibilidade e a especificidade de um método cromatográfico. Já analisamos alguns destes fatores para CCD, ou seja, a contribuição da fase estacionária e do agente cromogênico. Para os outros métodos cromatográficos pesam tambem muitas variáveis, como por exemplo, tipos de coluna, detectores, fase móvel, agente de derivatização, tipo de ionização (CG/MS), etc.

CCD e CLAE são capazes de detectar baixas concentrações de THCCOOH sem necessidade de derivatização prévia. Contudo, a detecção por visualização química (CCD), absorção no ultravioleta ou detecção eletroquimica (CLAE-UV e CLAE-DE) são de especificidade moderada15. PEAT ${ }^{113}$ trabalhou com CLAE acoplada a RIA.

Enquanto $\triangle^{9}-\mathrm{THC}$ pode ser analisado diretamente por CG e CG/MS, O THCCOOH precisa ser derivatizado, devido à sua alta polaridade e à tendência que os ácidos carboxílicos têm de sofrerem descarboxilação em altas temperaturas. A escolha do agente de derivatização afeta em muito o cromatograma, tanto na separação de outros compostos quanto no limite de detecção ${ }^{15}$.

Das várias técnicas que têm sido usadas para identificar e quantificar canabinóides em fluidos biológicos, a cromatografia gasosa acoplada à espectrometria de massa (CG/MS) é geralmente considerada técnica que fornece identificação inequívoca. Isto porque o CG/MS possui alta especificidade e sensibilidade, características estas que, entretanto, dependem de muitos fatores. Como exemplo, a 
eficiência dos procedimentos de extração e derivatização, a qualidade do cromatograma, o método de ionização, a análise de massa e a sofisticação do processo de manuseio da informação (qualidade de comparação do computador maior ou igual a 98\%). Conseqüentemente, o uso de CG/MS para análise de canabinóides não necessariamente assegura que a mais alta sensibilidade foi alcançada, nem que a identificação será conclusiva. Operações ótimas do sistema CG/MS requerem um especialista competente e com experiência, e práticas adequadas de controle de qualidade 45 .

JONES e cols 74 analisaram 29 amostras de urina por 5 métodos cromatográficos diferentes. Os resultados mostraram boa correlação entre cromatografia líquida de alta eficiência com detector de ultravioleta (CLAE-UV), cromatografia gasosa com detectores de captura eletrônica (CG-DEC) e cromatografia gasosa com detector de ionização de chama ( CG-DIC) com 3 diferentes colunas: OV-17, DB-1 e DB-5.

Vários autores trabalharam com CLAE utilizando detector de UV e detector eletroquímico (DE). Eles citam limites de deteç̧ão de $50 \mathrm{ng} / \mathrm{ml}$ trabalhando com $5 \mathrm{ml}$ de urina e de $20 \mathrm{ng} / \mathrm{ml}$ para $10 \mathrm{ml}$ de amostra. A análise dos resultados de CLAE-DE mostrou menores coeficientes de variação, apontando para um precisão maior65,64,12,42.

Os métodos que utilizam a cromatografia gasosa são dependentes de derivatização. O CG-DIC é o menos sensível, necessitando de grandes volumes de amostra. O CG-DCE ganha em sensibilidade, podendo detectar canabinóides em $1 \mathrm{ml}$ de amostra, dependendo do agente de derivatização e do solvente de extração. Contudo, ele perde em especificidade, pois as reações de derivatização geram interferentes oriundos de co-extração dos tecidos ${ }^{11,40}$. Um novo detector para CG, 0 ITD ( Ion Trap Detector) permite a confirmação de $\mathrm{THCCOOH}$ em urinas com menos de $10 \mathrm{ng} / \mathrm{ml}$, utilizando-se $10 \mathrm{ml}$ de amostra ${ }^{97}$.

Alguns autores consideram o uso da CCD como técnica de confirmação aceitável em várias situações. SUTHEIMER e cols ${ }^{131}$ e KOGAN e col90 e WILLSON e col144 citam $100 \%$ de confiabilidade na confirmação de amostras positivas por EMIT\& ("cutoff" $100 \mathrm{ng} / \mathrm{ml}$ ) e, trabalhando com "cutoff" de $20 \mathrm{ng} / \mathrm{ml}$, apenas $4,6 \%$ dos resultados correm risco de não serem confirmados usando-se CCD convencional.

FREDERICK e cols ${ }^{47}$ observaram no EMIT(12-3\% de resultados não confirmados por outras técnicas.CCD mostrou ser uma boa técrica de confirmação para EMIT® com eliminação de todos os positivos não confirmados.

Excelente correlação foi encontrada na fase de confirmação, quando amostras positivas por EMIT@ eram analisadas por CLAE-UV ,CLAE-DE e CCDAE. A confiabilidade nos resultados foi de $100 \%$ para concentrações maiores que $20 \mathrm{ng} / \mathrm{ml} 65,64$. 
BLACK e cols ${ }^{12}$ avaliaram 60 amostras de urina por EMIT® ("cutoff" 20ng/ml), CLAE e CCDAE. Os resultados negativos foram todos concordantes. Houve $100 \%$ de correlação entre CLAE e CCDAE para resultados positivos.

VINSON e LOPATOFSKY135 citam um estudo onde 560 urinas triadas como positivas por EMIT® ("cutoff" $20 \mathrm{ng} / \mathrm{ml}$ ) foram analisadas por CCDAE. Destas, 517 $(92,3 \%)$ foram confirmadas positivas por CCDAE. Em 43 amostras não confirmadas, 28 tratava-se de falsos positivos, e 15 não foram confirmadas, possivelmente por perdas na extração ou por interferentes apresentados na urina, que diminuiam a visualização das bandas de $\mathrm{THCCOOH}$. Utilizando-se um "cutoff" maior para triagem (p.e.50ng/ml), a possibilidade de confirmação aumenta72.

FOLTZ ${ }^{45}$, em 1984, e BRONNER e cols ${ }^{15}$, em 1992, realizaram estudos de revisão quanto às metodologias empregadas na fase de confirmação por CG/MS. Eles discutem vários aspectos inerentes a essa técnica, como a escolha do agente de derivatização, do solvente extrator, de processo de purificação, método de ionização, etc. Apesar de a técnica de ionização mais empregada ser a do impacto eletrônico, o método mais sensivel que foi reportado baseia-se na conversão do $\mathrm{THCCOOH}$ em seu éster trifluoroacetato, que é analisado por ionização química-ion negativo $(\mathrm{NICl})$. Devido a sua alta eficiência de ionização e seletividade, menos que $0,1 \mathrm{ng}$ de $\mathrm{THCCOOH}$, pode ser quantificado em $1 \mathrm{ml}$ de sangue, plasma ou urina. Ele também pode ser usado para análise de $\mathrm{THC}, 11-\mathrm{OH}-\mathrm{THC}$ e THCCOOH em uma única amostra de $1 \mathrm{ml}$ de sangue 45 . Quando se trabalha com impacto eletrônico, o melhor derivado seria o trimetilsilili15. Outras referências podem ser consultadas para análise em CG/MS 10,68,35,38,146,115,125,23. 
3. Objetivo e plano de trabalho

O objetivo deste trabalho foi estudar uma metodologia analítica para detecção de usuários de Cannabis aplicável às condições existentes nos laboratórios de toxicologia do Brasil.

Para atingir este objetivo, adotou-se o seguinte plano de trabalho:

1. Revisão dos métodos cromatográficos e imunológicos existentes na literatura para identificação de usuários de Cannabis;

2. Seleção e estudo de uma metodologia para identificação do principal produto de biotransformação do $\Delta^{9}$-tetrahidrocanabinol (THC), o 11-nor-9-carboxi- $\Delta^{9}$-tetrahidrocanabinol (THCCOOH), em urina, por cromatografia em camada delgada de alta eficiência (CCDAE);

3. Aplicação do método padronizado de CCDAE em urina de usuários e não-usuários de Cannabis;

4. Análise das amostras selecionadas por imunoensaio de fluorescência polarizada

5. Avaliação da correspondência entre os resultados obtidos nas técnicas estudadas. 
4. Material e Métodos

\subsection{Material}

\subsubsection{Equipamentos}

Vitalab Eclair®, Merck

Agitador mecânico

Centrífuga

Banho de água

4.1.2. Reagentes para Imunoensaio:

dau-TRAK® para canabinóides, MercK

Tampão borato de sódio $10 \mathrm{mmo} / /$, Merck

dau-TRAK@ Multicontrole, Merck

4.1.3 Solventes e soluções e agente cromogênico

n-Hexano p.a.

n-Butanol p.a.

n-Heptano p.a.

Clorofórmio p.a.

Metanol p.a.

Ácido acético glacial p.a.

dietilamina p.a.

$\mathrm{NaOH} 1 \mathrm{~N}$

$\mathrm{HCl} 1 \mathrm{~N}$

$\mathrm{KOH} 11,8 \mathrm{~N}$

Fast Blue BB 0,1\% em $\mathrm{H}_{2} \mathrm{O}: \mathrm{MeOH} 9: 1$

4.1.4 Cromatoplacas HPTLC-60 F250, Merck

\subsubsection{Nitrogênio}

4.1.6 Soluções-padrão

Solução-padrão de THCCOOH a $5 \%$, em etanol

Solução-padrão de THCCOOH a 0,5\% em etanol 


\subsubsection{Amostras de urina}

As amostras de urinas foram classificadas nos seguintes grupos:

Grupo I - Amostras de urina de usuários de Cannabis em três diferentes padrões de uso: ocasional ("leve"), moderado, intenso ("pesado").Vide tabela 9

Grupo II - Amostras de urina com resultado positivo para canabinóides, fornecidas pelo Laboratório de Análises Toxicológicas da Faculdade de Ciências Farmacêuticas USP - São Paulo.

Grupo III -Amostras de urina provenientes de uma instituição para recuperação de dependentes químicos.

Grupo IV- Grupo controle. Amostras de urina de individuos que não faziam uso de Cannabis,

Tabela 9. Padrão de uso e mometo de coleta das amostras de usuánios do grupo I.

\begin{tabular}{|c|c|c|}
\hline Amostra* & Padrão de uso $o^{\star \star}$ & $\begin{array}{l}\text { Momento de coleta após } \\
\text { exposição a } 1 \text { cigarro de Cannabis }\end{array}$ \\
\hline $1 \mathrm{~A}$ & - & desconhecido \\
\hline $1 \mathrm{~B}$ & - & dentro de 24 horas \\
\hline 2 & - & desconhecido \\
\hline $3 \mathrm{~A}$ & - & desconhecido \\
\hline $3 B$ & - & desconhecido \\
\hline 4 & "pesado" & desconhecido \\
\hline 5 & "pesado" & desconhecido \\
\hline $6 \mathrm{~A}$ & moderado & 24 horas \\
\hline $6 \mathrm{~B}$ & moderado & 48 horas \\
\hline $6 \mathrm{C}$ & moderado & 72 horas \\
\hline $7 A$ & "pesado" & 1 hora \\
\hline $7 \mathrm{~B}$ & "pesado" & 7 horas \\
\hline $8 \mathrm{~A}$ & ocasional & dentro de 24 horas \\
\hline $8 B$ & ocasional & desconhecido \\
\hline $9 A$ & ocasional & durante a exposição \\
\hline 10 & ocasional & 36 horas \\
\hline $11 \mathrm{~A}$ & ocasional & 5 horas \\
\hline 11B & ocasional & 12 horas \\
\hline $11 C$ & ocasiional & 24 horas \\
\hline $11 \mathrm{D}$ & ocasional & 48 horas \\
\hline $11 E$ & ocasional & 72 horas \\
\hline $12 A$ & ocasional & 48 horas \\
\hline $12 B$ & ocasional & 72 horas \\
\hline
\end{tabular}

* Cada número refere-se a um mesmo indivíduo: as letras significam horários diferentes de coleta.

** Foi adotada a mesma classificação de Mulé e col. : :ocasional(1/semana), moderado (2-3/semana) e "pesado" (1 ou mais/dia). 


\subsection{Métodos}

4.2.1 Identificação por cromatografia em camada delgada de alta eficiência.

4.2.1.1 Determinação do limite de detecção da técnica de cromatografia em camada delgada de alta eficiência para análise do $\mathrm{THCCOOH}$.

Quantidades variadas de THCCOOH foram aplicadas à placa de CCDAE $(5,10,20,50,100,250 n g)$. As condições cromatográficas são as do método de MEATHERALL e GARRIOTT e estão especificadas abaixo:

Adsorvente

Sistema solvente

Tempo de saturação da cuba

Local de aplicação do resíduo

Percurso da fase móvel

Agentes cromogênicos
- silica gel

- n-heptano:n-butanol:ac.acét. glacial (90:9:1)

- 15 minutos

- $1 \mathrm{~cm}$ da extremidade da placa

- 7,5 cm a partir do ponto de aplicação

- dietilamina $\rightarrow$ Fast Blue 0,1\% em $\mathrm{H}_{2} \mathrm{O}: \mathrm{MeOH}$

4.2.1.2 Aplicação do método de MEATHERALL e GARRIOTT a adicionados de $\mathrm{THCCOOH}$.

Aplicação do método de MEATHERALL e GARRIOTT às amostras do grupo IV ( brancos controles) adicionadas de quantidades variadas de THCCOOH para obtenção de concentrações equivalentes a 5,10 e $20 \mathrm{ng} / \mathrm{ml}$ de $\mathrm{THCCOOH}$. Os adicionados foram preparados em triplicatas de cada concentração

Com intercalação aos pontos de aplicação dos resíduos dos adicionados, colocaram-se quantidades variadas de $\mathrm{THCCOOH}$ para uma estimativa visual, ainda que subjetiva, da "recuperação"do método.

\section{Método de MEATHERALL e GARRIOTT (método A)}

Colocar $5 \mathrm{ml}$ em tubo de centrífuga de $15 \mathrm{ml}$. Adicionar $0,5 \mathrm{ml}$ de solução de $\mathrm{NaOH}$ $1 \mathrm{~N}$. Levar o tubo ao banho-maria $\left(50-60^{\circ} \mathrm{C}\right)$ por 15 minutos. Após resfriamento, acidificar com $1 \mathrm{ml}$ de $\mathrm{HCl} 1 \mathrm{~N}$. Adicionar $5 \mathrm{ml}$ de $n$-hexano e submeter os tubos a agitação mecânica suave por 20 minutos. Centrifugar a $1000 \mathrm{~g}$ por 5 minutos. Transferir o * de urina 
solvente com auxilio de pipeta pasteur para um tubo pequeno e largo, de fundo redondo, e evaporar a temperatura ambiente, com auxilio de corrente de ar seco. Após evaporação do solvente, ressuspender 0 resíduo com $3-4$ gts da mistura clorofórmio:metanol 3:1 e transferir quantitativamente para as placas de CCDAE.

Fluxograma do método $\mathrm{A}$

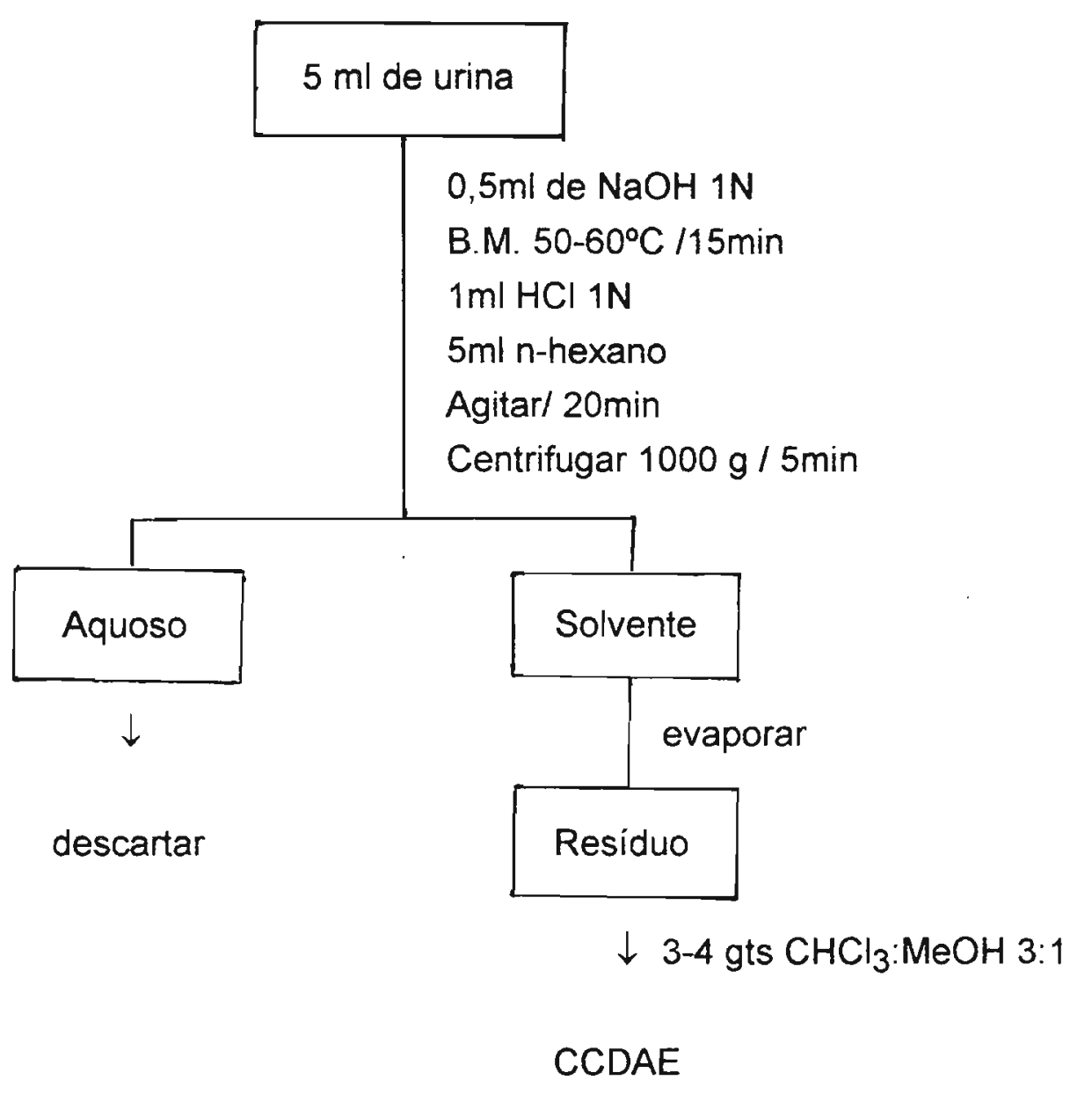

4.2.1.3 Aplicação do método de MEATHERALL e GARRIOTT às amostras de usuários (grupo I), e brancos de referência (grupo IV).

Paralelamente às amostras de usuários, foram analisadas as de voluntários que não faziam uso de Cannabis (branco de referência) e adicionados contendo $20 \mathrm{ng} / \mathrm{ml}$ de

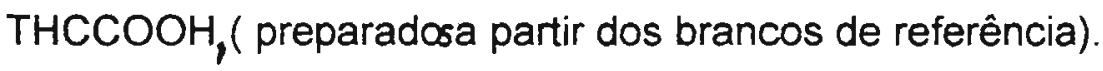


4.2.1.4 Aplicação do método de MEATHERALL e GARRIOTT modificado às amostras de usuários (grupo I), amostras fornecidas pelo LAT (grupo II), amostras enviadas por uma clínica de recuperação de farmacodependentes (grupo III) e brancos de referência (grupo IV).

Método de MEATHERALL e GARRIOTT modificado (método B)

Colocar $5 \mathrm{ml}$ de urina em um tubo de centrifuga de $15 \mathrm{ml}$. Adicionar $0,5 \mathrm{ml}$ de $\mathrm{KOH}$ $11.8 \mathrm{~N}$. Deixar em repouso por $5 \mathrm{~min}$ a temperatura ambiente. Acidificar com $1,4 \mathrm{ml}$ de acido acético glacial. Adicionar $5 \mathrm{ml}$ de $n$-hexano e prosseguir conforme o método desccrito em 4.2.1.2.

\section{Fluxograma do Método B}

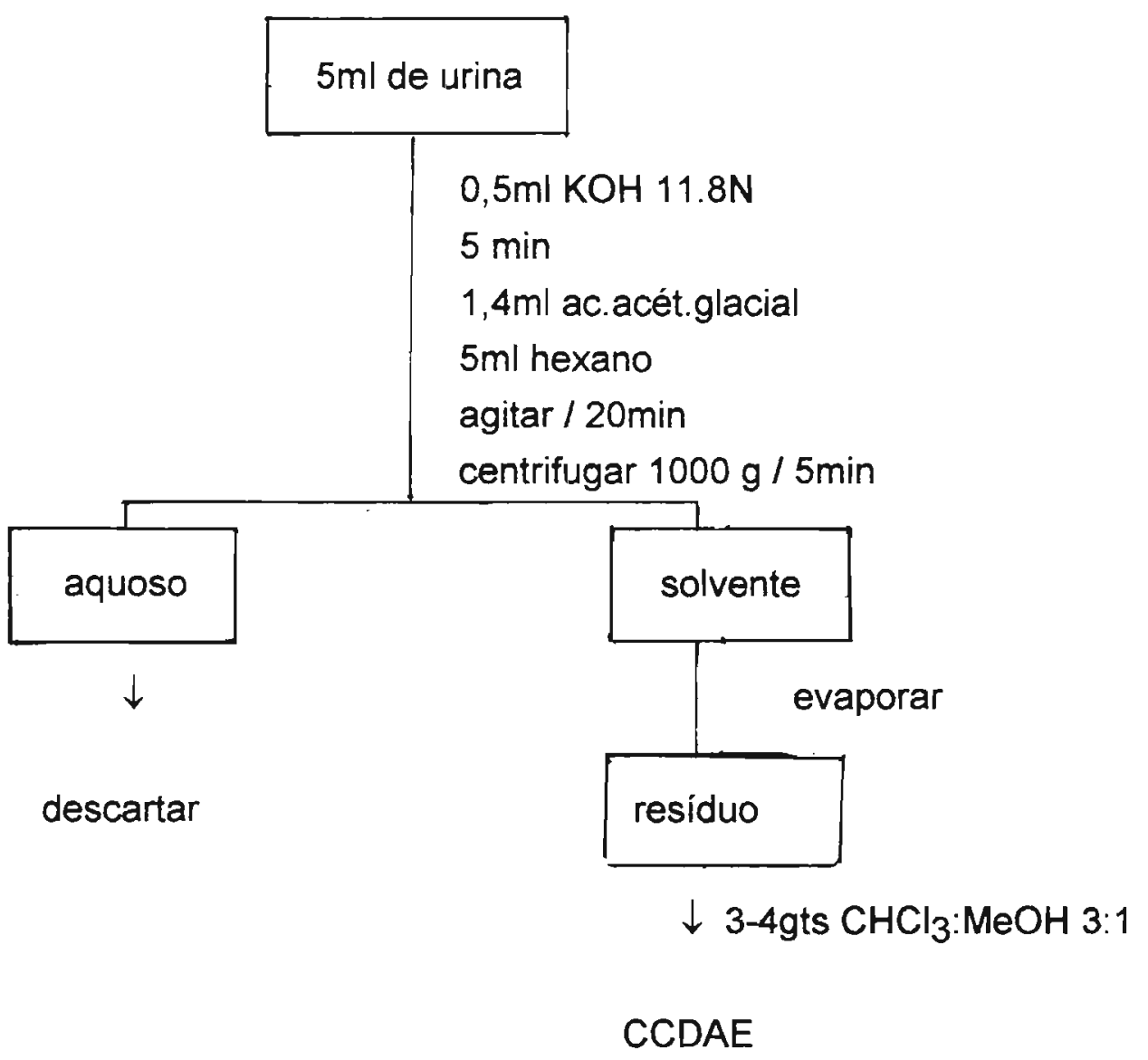




\subsubsection{Imunoensaio de fluorescência polarizada}

4.2.2.1 Aplicação do método de imunoensaio de fluorescência polarizada às amostras selecionadas para esse estudo. Utilizou-se o método preconizado pelo fabricante:

1. Colocar $10 \mu$ do controle médio (cutoff) em um tubo de ensaio e $1 \mathrm{ml}$ do tampão (branco

do controle). Em outro tubo de ensaio colocar $10 \mu \mathrm{l}$ do controle e $1 \mathrm{ml}$ do reagente.

Deixar os tubos por 12 minutos na unidade de incubação. Calibrar o aparelho com esta

solução.

2. Repetir o mesmo processo com os controles baixo e alto. Ler os controles.

3. Colocar $10 \mu \mathrm{l}$ da amostra em 2 tubos de ensaio. Em um deles adicionar $1 \mathrm{ml}$ de tampão

e no outro $1 \mathrm{ml}$ do reagente. Incubar por 12 min e ler branco e amostra.

4.2.2.2 Construção da curva-padrão para estudo do método de imunoensaio de fluorescência polarizada na detecção de $\mathrm{THCCOOH}$ em urina.

Com o objetivo de estudar a correlação entre concentração de $\mathrm{THCCOOH}$ presente nas amostras e polarização da fluorescência, foi construída curva-padrão utilizando os próprios controles fornecidos pelo fabricante (dau-TRAK®Multicontrole), de acordo com as condições apresentadas na tabela 10.

Tabela 10. Preparação da cunva-padrão referente a análise de $\mathrm{THCCOOH}$ por imunoensaio de fluorescéncia polanizada.

\begin{tabular}{lccc}
\hline $\begin{array}{c}\text { Controle } \\
\text { tipo/concentração }\end{array}$ & $\begin{array}{c}\text { volume } \\
\text { utilizado }\end{array}$ & $\begin{array}{c}\mathrm{THCCOOH} \\
(\mathrm{ng})\end{array}$ & $\begin{array}{c}\text { volume do } \\
\text { reagente }\end{array}$ \\
\hline baixo $/ 20 \mathrm{ng} / \mathrm{ml}$ & $10 \mu \mathrm{l}$ & 0,020 & $1 \mathrm{ml}$ \\
baixo & $18 \mu \mathrm{l}$ & 0,036 & $1 \mathrm{ml}$ \\
cutoff $/ 50 \mathrm{ng} / \mathrm{ml}$ & $10 \mu \mathrm{l}$ & 0,050 & $1 \mathrm{ml}$ \\
cutoff + baixo & $10 \mu l+13 \mu \mathrm{l}$ & 0,076 & $1 \mathrm{ml}$ \\
cutoff & $20 \mu \mathrm{l}$ & 0,100 & $1 \mathrm{ml}$ \\
atto $/ 500 \mathrm{ng} / \mathrm{ml}$ & $4 \mu \mathrm{l}$ & 0,200 & $1 \mathrm{ml}$ \\
alto & $10 \mu \mathrm{l}$ & 0,500 & $1 \mathrm{ml}$ \\
\hline
\end{tabular}


Com a chegada de uma nova remessa de reagentes uma segunda curva-padrão foi confeccionada tendo em vista que os resultados obtidos com a análise das amostras por esses reagentes não poderiam ser comparados com a primeira curva-padrão. As condições preparação foram as mesmas adotadas para a primeira curva. 
5. Resultados

5.1 Determinação do limite de detecção da técnica de cromatografia em camada delgada de alta eficiência para análise do $\mathrm{THCCOOH}$.

Após aplicação de quantidades variadas de $\mathrm{THCCOOH}$ à placa de $\mathrm{CCDAE}$, a menor quantidade visualizada foi 10ng.

5.2 Aplicação do método de MEATHERALL e GARRIOTT a adicionados de $\mathrm{THCCOOH}$.

Os resultados obtidos com a análise de adicionados de $\mathrm{THCCOOH}$ permitiu uma avaliação visual, ainda que subjetiva, do método. Os adicionados de $20 \mathrm{ng} / \mathrm{ml}$ tinham bandas comparáveis às produzidas por mais de 50 e menos de $100 \mathrm{ng}$ de $\mathrm{THCCOOH}$. Os adicionados de $10 \mathrm{ng} / \mathrm{ml}$ tinham bandas correlacionadas com $30 \mathrm{ng}$ de $\mathrm{THCCOOH}$ e os de $5 \mathrm{ng} / \mathrm{ml}$ com menos de $20 \mathrm{ng}$ de $\mathrm{THCCOOH}$.

5.3 Aplicação do método de MEATHERALL e GARRIOTT a amostras de usuários de Cannabis (grupo I e IV).

As amostras de usuários fo grupo I foram submetidas aqmétodo $A$. As manchas obtidas foram visualmente comparadas com quantidades conhecidas de $\mathrm{THCCOOH}$ aplicadas diretamente à placa, e os resultados estão na tabela 11.

Nenhuma das amostras do grupo IV (branco de referência) forneceu mancha da mesma cor e hRf do padrão de $\mathrm{THCCOOH}$. 
Tabela 11 - Resultado da análise por CCDAE das amostras de usuários de Cannabis (grupo I) pelo método de MEATHERALL e GARRIOTT ( método A).

\begin{tabular}{|c|c|c|}
\hline & Amostra & CCDAE (método A) \\
\hline$:$ & $\begin{array}{c}1 \mathrm{~A} \\
1 \mathrm{~B} \\
2 \\
3 \mathrm{~A} \\
3 \mathrm{~B} \\
3 \mathrm{C} \\
4 \\
5 \\
6 \mathrm{~A} \\
6 \mathrm{~B} \\
6 \mathrm{C} \\
7 \mathrm{~A} \\
7 \mathrm{~B} \\
8 \mathrm{~A} \\
8 \mathrm{~B} \\
9 \mathrm{~A} \\
9 \mathrm{~B} \\
10 \\
11 \mathrm{~A} \\
11 \mathrm{~B} \\
11 \mathrm{C} \\
11 \mathrm{D} \\
11 \mathrm{E} \\
12 \mathrm{~A} \\
12 \mathrm{~B}\end{array}$ & $\begin{array}{l}- \\
+ \\
+ \\
- \\
++ \\
- \\
+++ \\
+++ \\
++ \\
+ \\
+ \\
+++ \\
+++ \\
+ \\
\mathrm{ND} /+ \\
\mathrm{ND} \\
\mathrm{ND} \\
++ \\
++ \\
++ \\
+ \\
+ \\
\mathrm{ND} /+ \\
+ \\
+\end{array}$ \\
\hline Legenda: & \multicolumn{2}{|c|}{$\begin{array}{l}+ \text { comparáveis a } 20-50 \mathrm{ng} / \mathrm{ml} \text { THCCOOH } \\
++ \text { comparáveis a } 100 \mathrm{ng} / \mathrm{ml} \text { THCCOOH } \\
+++ \text { comparáveis a }>200 \mathrm{ng} / \mathrm{ml} \text { THCCOOH } \\
\text { ND não detectado } \\
(-) \text { amostras não analisadas }\end{array}$} \\
\hline
\end{tabular}


5.4 Aplicação do método de MEATHERALL e GARRIOTT modificado (método B) às amostras de usuários (grupo I), amostras fornecidas pelo LAT (grupo II) e amostras enviadas por uma clínica de recuperação de farmacodependentes (grupo III).

\section{Tabela 12 - Resultado da análise por CCDAE das amostras de usuánios de Cannabis do grupo I pelo método de MEATHERALL e GARRIOTT modificado (método $B$ ), utilizando $3 \mathrm{ml}$ de amostra.}

\begin{tabular}{cc}
\hline Amostra & CCDAE(método B) \\
\hline $1 \mathrm{~A}$ & ++ \\
$1 \mathrm{~B}$ & + \\
2 & $\mathrm{ND}$ \\
$3 \mathrm{~A}$ & +++ \\
$3 \mathrm{~B}$ & ++ \\
$3 \mathrm{C}$ & +++ \\
4 & +++ \\
5 & +++ \\
$6 \mathrm{~A}$ & + \\
$6 \mathrm{~B}$ & + \\
$6 \mathrm{C}$ & + \\
$7 \mathrm{~A}$ & +++ \\
$7 \mathrm{~B}$ & + \\
$8 \mathrm{~A}$ & $\mathrm{ND}$ \\
$8 \mathrm{~B}$ & $\mathrm{ND}$ \\
$9 \mathrm{~A}$ & + \\
10 & + \\
$11 \mathrm{~A}$ & + \\
$11 \mathrm{~B}$ & + \\
$11 \mathrm{C}$ & $\mathrm{ND}$ \\
$11 \mathrm{D}$ & + \\
$11 \mathrm{E}$ & + \\
$12 \mathrm{~A}$ & \\
$12 \mathrm{~B}$ & \\
& + \\
+ & comparáveis a $20-50 \mathrm{ng} / \mathrm{ml} \mathrm{THCCOOH}$ \\
++ & comparáveis a \\
+++ comparáveis a mais de $200 \mathrm{HCCO} / \mathrm{ml} \mathrm{THCCOOH}$ \\
ND= não detectado
\end{tabular}

As figuras 12 e 13 são fotografias de cromatogramas típicos obtidos por esta metodologia. 


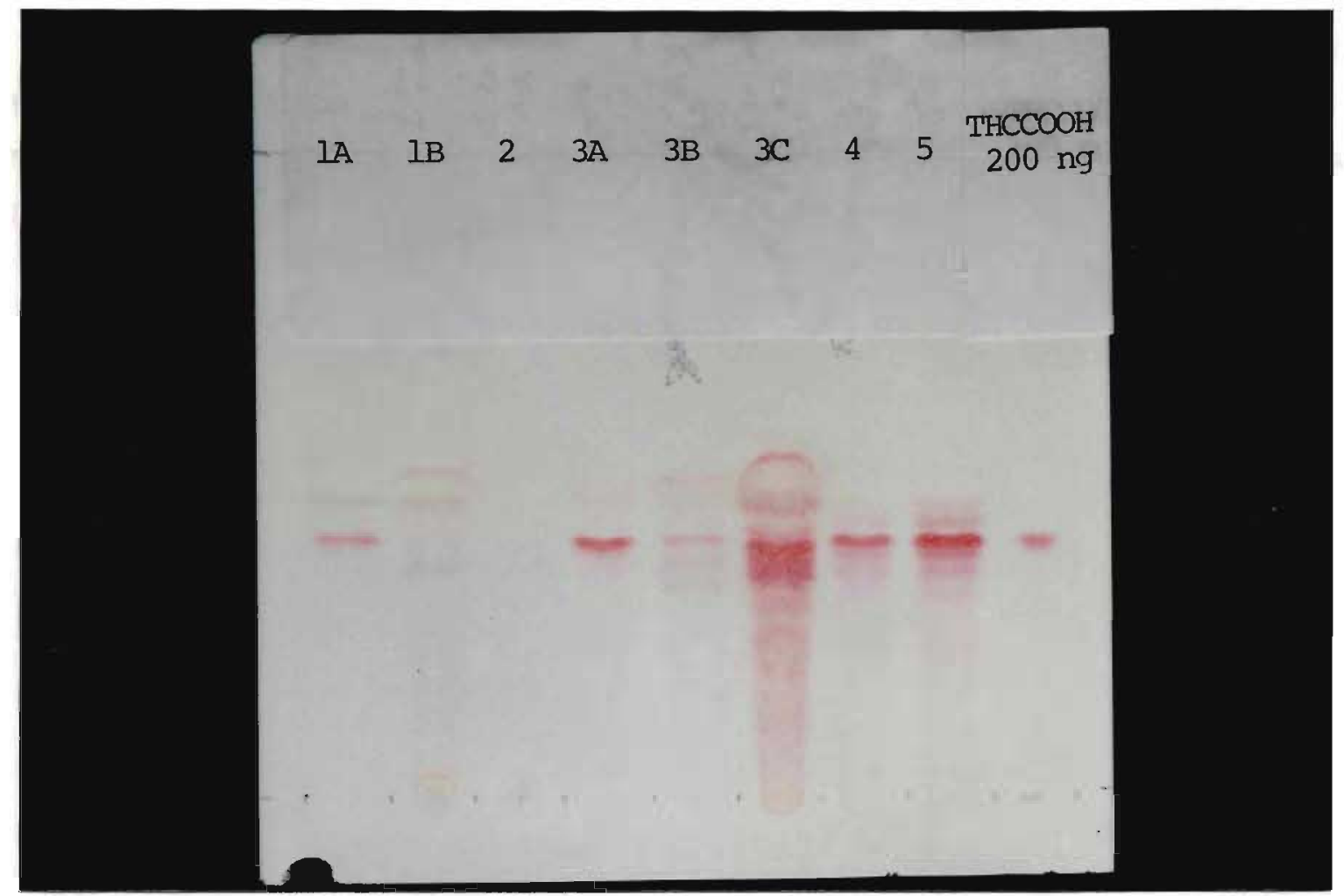

Figura 12. Cromatograma típico obtido com a aplicação do método de MEATHERALL e GARRIOTT às amostras de usuários de Cannabis.

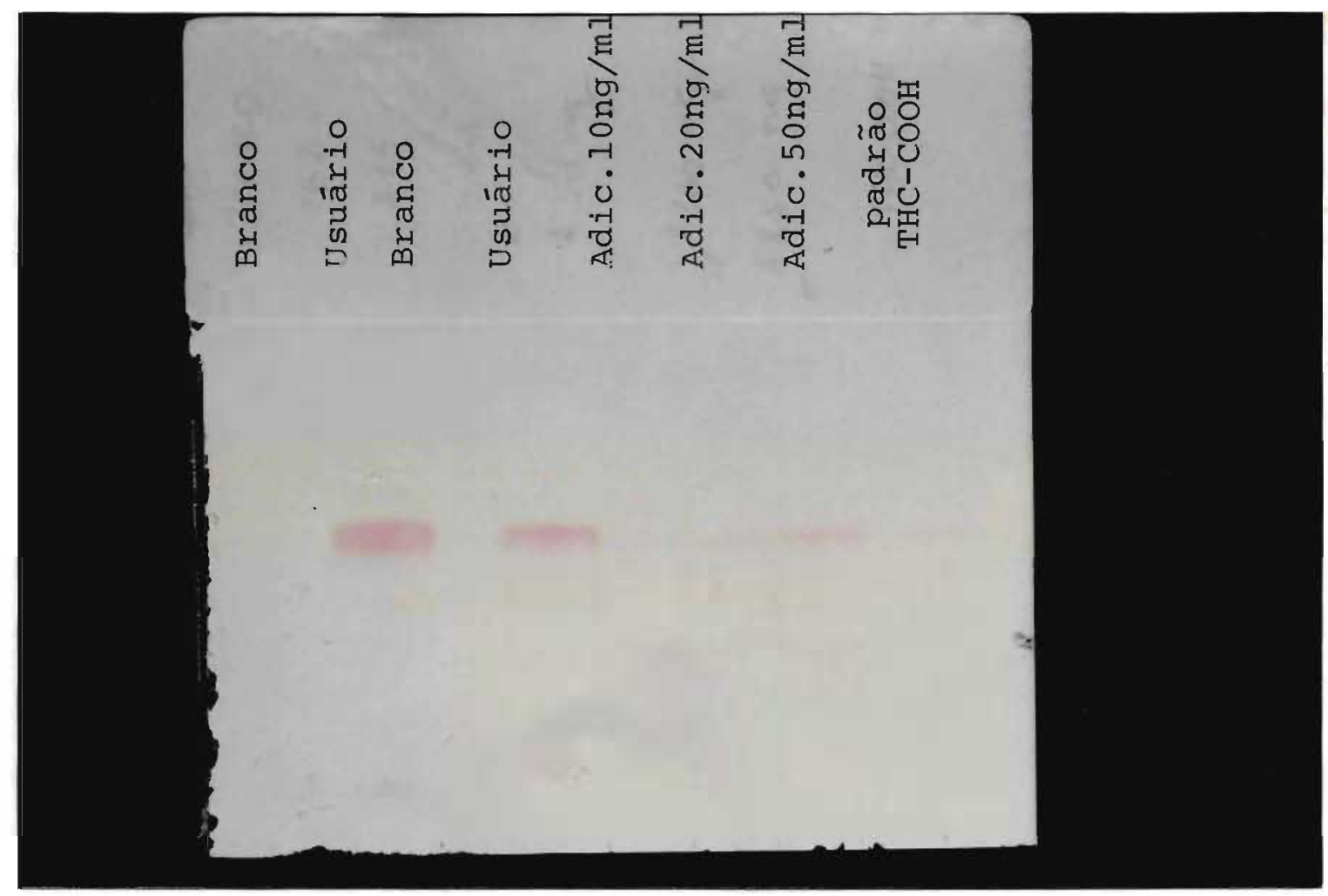

Figura 13. Cromatograma típico obtido com a aplicação do método de MEATHERALL e GARRIOTT às amostras de usuários de Cannabis 
Os valores de hRf obtidos do padrão de $\mathrm{THCCOOH}$, acompanhados dia a dia, num total de dezesseis determinações, apresentaram valor médio igual a 34 , com desvio-padrão $=3$ e coeficiente de variação $=8,82 \%$. Não foi observada variação significativa no hRf para uma mesma placa.

Tabela 13 - Resultados da análise por CCDAE das amostras de usuánios de Cannabis do grupo II pelo método de MEATHERALL E GARRIOTT modificado (método B).

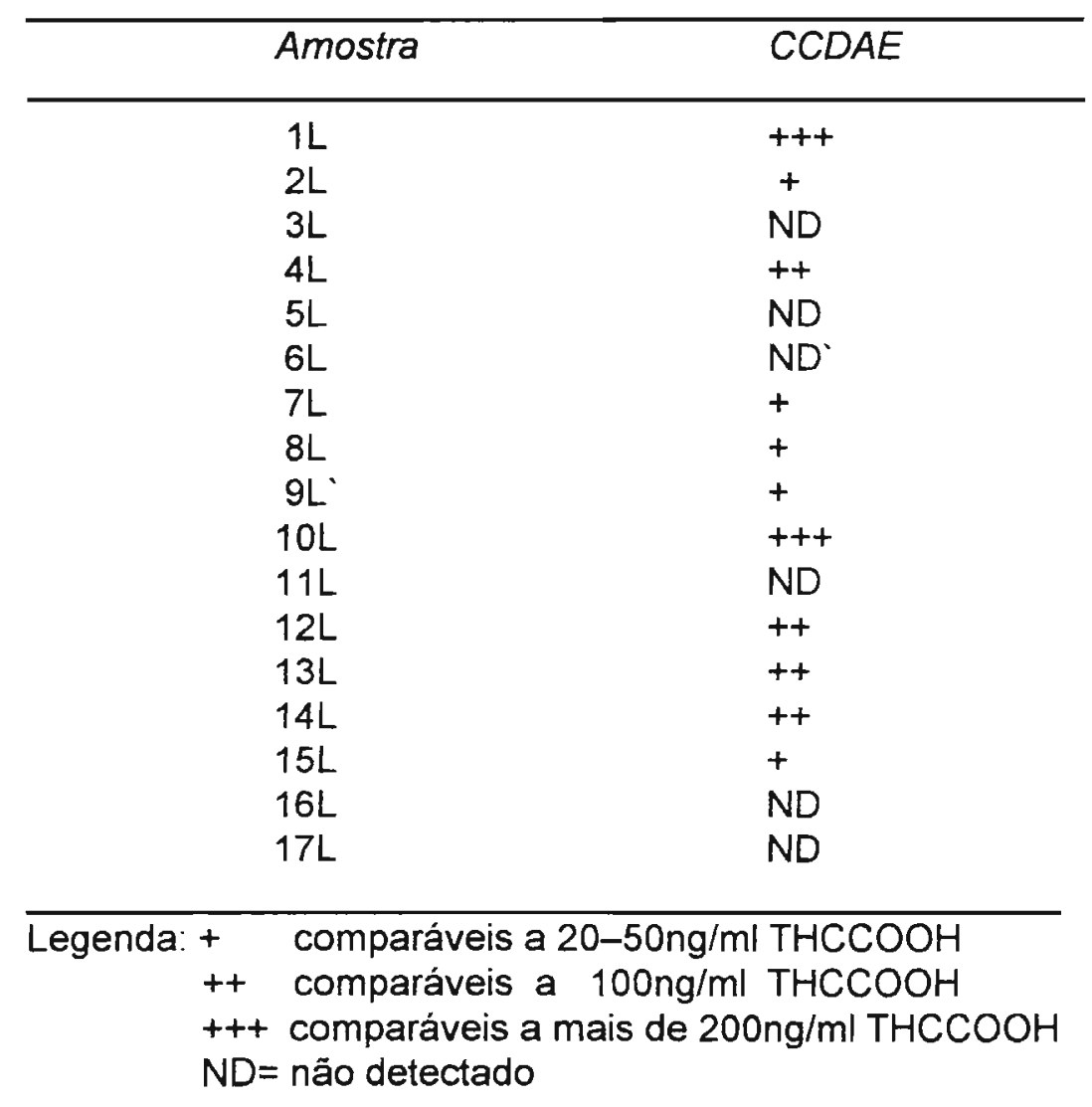


Tabela 14 - Resultados da análise por CCDAE das amostras de usuários de Cannabis do grupo III pelo método de MEATHERALL e GARRIOTT modificado (método B).

\begin{tabular}{|c|c|c|}
\hline & Amostra & CCDAE \\
\hline & $1 \mathrm{~F}$ & +++ \\
\hline & $2 F$ & + \\
\hline & $3 F$ & + \\
\hline & $4 \mathrm{~F}$ & + \\
\hline & $5 F$ & + \\
\hline & $6 \mathrm{~F}$ & ++ \\
\hline & $7 F$ & + \\
\hline & $8 \mathrm{~F}$ & + \\
\hline & $9 F$ & ND \\
\hline & $10 \mathrm{~F}$ & ND \\
\hline & $11 \mathrm{~F}$ & ND \\
\hline & $12 \mathrm{~F}$ & + \\
\hline Legenda: & $\begin{array}{l}+\quad \text { comp } \\
++ \text { comp } \\
+++ \text { comp } \\
\mathrm{ND}=\text { não }\end{array}$ & $\begin{array}{l}\mathrm{g} / \mathrm{ml} \text { THCCOOH } \\
\text { l THCCOOH } \\
200 \mathrm{ng} / \mathrm{ml} \mathrm{THCCOOH}\end{array}$ \\
\hline
\end{tabular}


5.5 Aplicação do método de Imunoensaio de fluorescência polarizada às amostras de usuários de Cannabis.

Tabela 15 - Resultados obtidos no imunoensaio de fluorescência polarizada (FPIA) para amostras de usuários do grupo I, no "cutoff" de 20ng/ml.

\begin{tabular}{cl}
\hline Amostra & FPIA \\
\hline $1 \mathrm{~A}$ & positivo \\
$1 \mathrm{~B}$ & positivo \\
2 & positivo \\
$3 \mathrm{~A}$ & positivo \\
$3 \mathrm{~B}$ & positivo \\
$3 \mathrm{C}$ & positivo \\
4 & positivo \\
5 & positivo \\
$6 \mathrm{~A}$ & positivo* \\
$6 \mathrm{~B}$ & negativo \\
$6 \mathrm{C}$ & negativo* \\
$7 \mathrm{~A}$ & positivo \\
$7 \mathrm{~B}$ & positivo \\
$8 \mathrm{~A}$ & negativo \\
$8 \mathrm{~B}$ & negativo \\
$9 \mathrm{~A}$ & positivo \\
10 & positivo* \\
$11 \mathrm{~A}$ & negativo \\
$11 \mathrm{~B}$ & positivo \\
$11 \mathrm{C}$ & negativo \\
$11 \mathrm{D}$ & positivo \\
$11 \mathrm{E}$ & negativo \\
$12 \mathrm{~A}$ & positivo \\
$12 \mathrm{~B}$ & positivo \\
& \\
\hline próximo ao valor de "cutoff'. &
\end{tabular}


Tabela 16 - Resultados obtidos no imunoensaio de fluorescéncia polarizada (FPIA) para amostras de usuários de Cannabis do grupo II, no "cutoff"de $20 \mathrm{ng} / \mathrm{ml}$.

\begin{tabular}{cl}
\hline Amostra & FPIA \\
\hline $1 L$ & positivo \\
$2 L$ & negativo \\
$3 L$ & negativo \\
$4 L$ & positivo \\
$5 L$ & negativo \\
$6 L$ & negativo \\
$7 L$ & positivo* \\
$8 L$ & negativo \\
$9 L$ & positivo* \\
$10 L$ & positivo \\
$11 L$ & negativo* \\
$12 L$ & positivo \\
$13 L$ & positivo \\
$14 L$ & positivo \\
$15 L$ & positivo \\
$16 L$ & positivo* \\
$17 L$ & negativo
\end{tabular}

" próximo ao valor de "cutoff". 
Tabela 17 - Resultados obtidos no imunoensaio de fluorescéncia polarizada (FPIA) para as amostras de usuánios de Cannabis do grupo III, no "cutoff"de 20ng/ml.

\begin{tabular}{cl}
\hline Amostra & FPIA \\
\hline $1 \mathrm{~F}$ & positivo \\
$2 \mathrm{~F}$ & positivo \\
$3 \mathrm{~F}$ & negativo* \\
$4 \mathrm{~F}$ & positivo \\
$5 \mathrm{~F}$ & positivo \\
$6 \mathrm{~F}$ & positivo \\
$7 \mathrm{~F}$ & negativo* \\
$8 \mathrm{~F}$ & negativo* \\
$9 \mathrm{~F}$ & negativo \\
$10 \mathrm{~F}$ & negativo \\
$11 \mathrm{~F}$ & negativo \\
$12 \mathrm{~F}$ & positivo
\end{tabular}

* próximo ao valor de "cutoff". 
5.6 Estudo da técnica de imunoensaio de fluorescência polarizada: construção da curva-padrão.

Os resultados da análise em triplicata de cada concentração estão relacionados na tabela 18.

Tabela18 - Resultados em milipolanizações ( $m P$ )obtidos no imunoensaio de fluorescência polanizada para diversas concentrações de $\mathrm{THCCOOH}$; desvio-padrão e coeficiente de variação calculados para cada concentração.

\begin{tabular}{|c|c|c|c|c|}
\hline Concentração & $\mathrm{mP}$ & média & DP & CV\% \\
\hline $20 \mathrm{ng} / \mathrm{ml}$ & $\begin{array}{l}140,4 \\
149,5 \\
150,4\end{array}$ & 146,7 & 5,53 & 3,76 \\
\hline $36 \mathrm{ng} / \mathrm{ml}$ & $\begin{array}{l}143,2 \\
140,8 \\
136,2\end{array}$ & 140,0 & 3,55 & 2,53 \\
\hline $50 \mathrm{ng} / \mathrm{ml}$ & $\begin{array}{l}139,2 \\
132,4 \\
133,7\end{array}$ & 135,1 & 3,60 & 2,66 \\
\hline $76 \mathrm{ng} / \mathrm{ml}$ & $\begin{array}{l}132,4 \\
129,8 \\
130,6\end{array}$ & 130,9 & 1,33 & 1,01 \\
\hline $100 \mathrm{ng} / \mathrm{ml}$ & $\begin{array}{l}124,1 \\
128,2 \\
123,5\end{array}$ & 125,2 & 2,55 & 2,03 \\
\hline $200 \mathrm{ng} / \mathrm{ml}$ & $\begin{array}{l}110,0 \\
112,9 \\
109,7\end{array}$ & 110,8 & 1,76 & 1,58 \\
\hline $500 \mathrm{ng} / \mathrm{ml}$ & $\begin{array}{l}101,4 \\
103,4 \\
101,1\end{array}$ & 101,9 & 1,25 & 1,22 \\
\hline
\end{tabular}

A figura 14 mostra a curva-padrão obtida. As curvas paralelas em traços alternados representam, respectivamente, 1 desvio-padrão (DP) e 2 DP. A análise através de regressão forneceu a seguinte equação: $\boldsymbol{y}=\boldsymbol{b} \boldsymbol{x}^{\boldsymbol{a}}$, onde $\boldsymbol{a}=-0,119459 \mathrm{e}$ $\boldsymbol{b}=\operatorname{Ln}$ a. Coeficiente de correlação $=-0,990378$. 


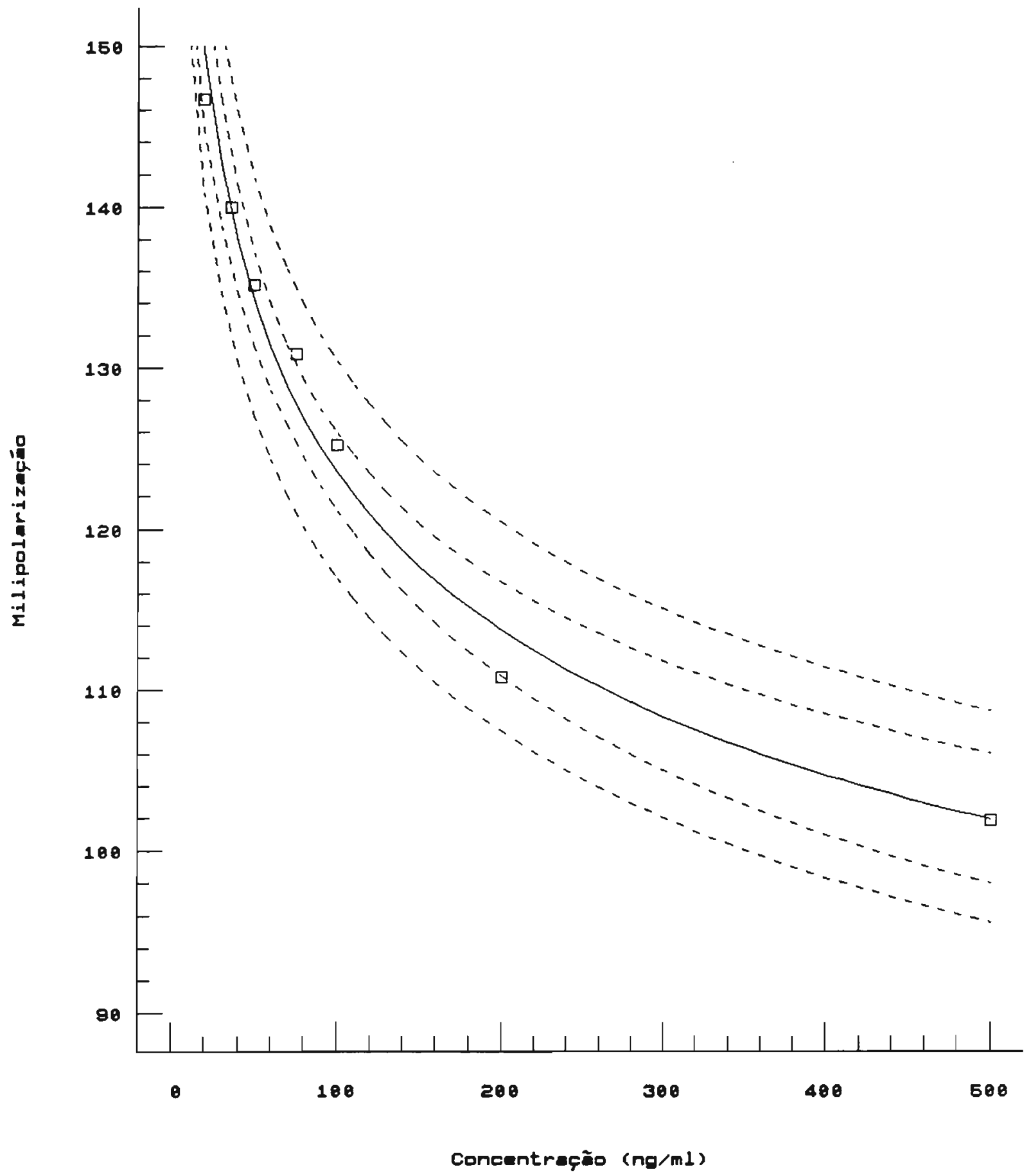

Figura 14. Curva-padrão obtida por imunoensaio de fluorescéncia polarizada (resultados expressos em milipolarizações - $m P$-), para diferentes concentrações de $\mathrm{THCCOOH}(\mathrm{ng} / \mathrm{ml})$. 
Os resultados da análise em triplicata de cada concentração para confecção da 2@ curva-padrão estão na tabela 19.

Tabela 19- Resultados em milipolarizações obtidos para confecção da 2@ curva-padrão. Desvio-padrão e coeficiente de variação calculados para cada concentração.

\begin{tabular}{|c|c|c|c|c|}
\hline Concentração & $\mathrm{mP}$ & média & DP & CV\% \\
\hline $20 \mathrm{ng} / \mathrm{ml}$ & $\begin{array}{l}135,9 \\
139,6 \\
138,3 \\
135,5\end{array}$ & 137,8 & 1,95 & 1,42 \\
\hline $36 \mathrm{ng} / \mathrm{ml}$ & $\begin{array}{l}131,9 \\
129,2 \\
126,5 \\
138,0 \\
139,5\end{array}$ & 133,0 & 5,59 & 4,20 \\
\hline $50 \mathrm{ng} / \mathrm{ml}$ & $\begin{array}{l}132,0 \\
130,9 \\
128,3 \\
127,3 \\
128,3\end{array}$ & 129,3 & 1,98 & 1,54 \\
\hline $76 \mathrm{ng} / \mathrm{ml}$ & $\begin{array}{l}123,6 \\
120,9 \\
124,3 \\
125,0\end{array}$ & 123,4 & 1,79 & 1,45 \\
\hline $100 \mathrm{ng} / \mathrm{ml}$ & $\begin{array}{l}109,8 \\
112,0 \\
119,8 \\
118,1\end{array}$ & 114,9 & 4,78 & 4,16 \\
\hline $200 \mathrm{ng} / \mathrm{ml}$ & $\begin{array}{l}98,0 \\
98,4 \\
101,5 \\
101,0\end{array}$ & 99,7 & 1,78 & 1,79 \\
\hline $500 \mathrm{ng} / \mathrm{ml}$ & $\begin{array}{l}92,9 \\
91,6 \\
93,4 \\
90,9\end{array}$ & 92,2 & 1,15 & 1,25 \\
\hline
\end{tabular}

$\mathrm{mP}=$ milipolarização 
A figura 15 mostra a curva-padrão obtida com estes resultados. Na equação $y=b x^{a}, a=-0,137084, b=\operatorname{Ln} a$, e o coeficiente de correlação obtido = $-0,979249$.

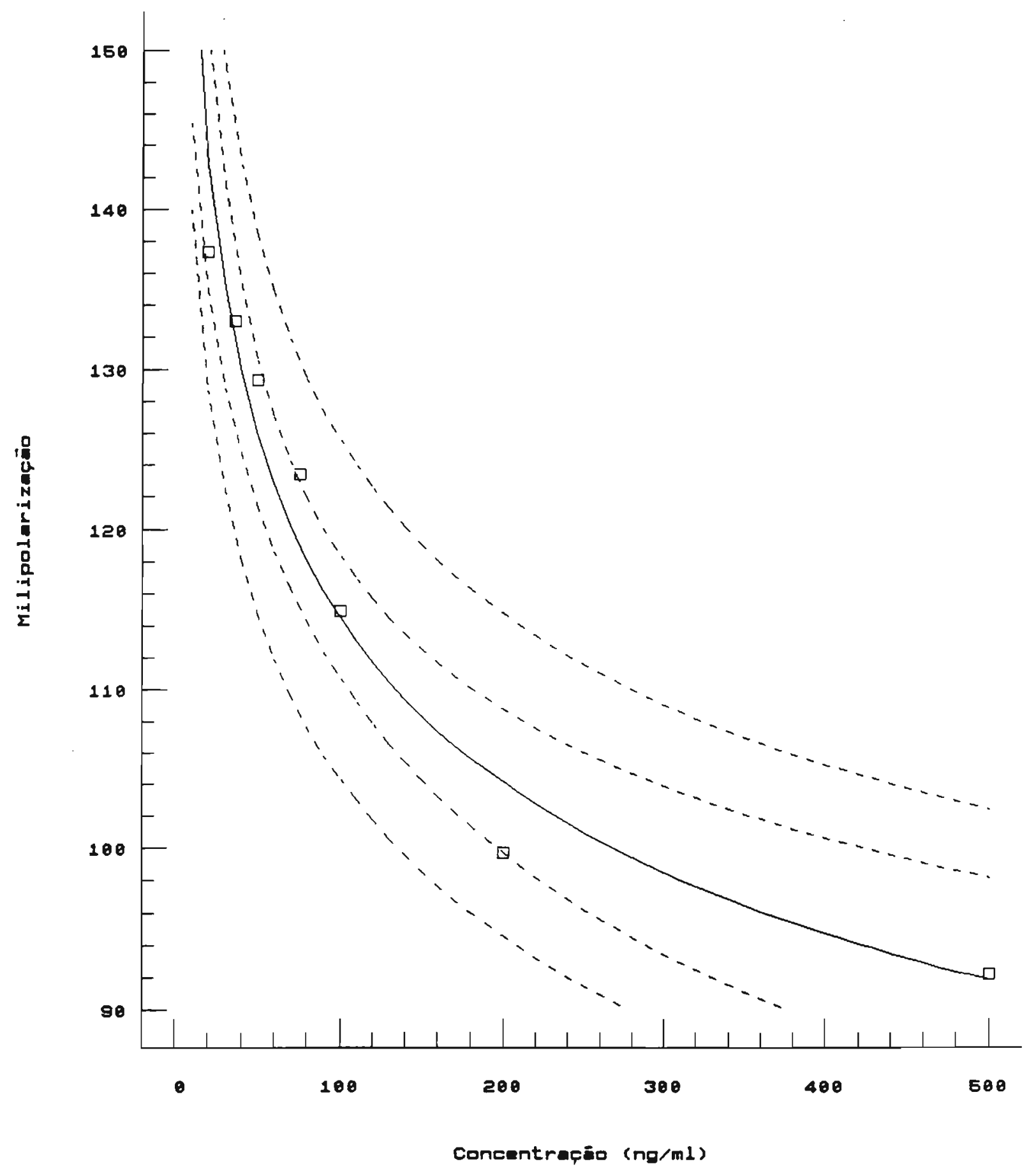

Figura 15. Curva-padrão obtidda por imunoensaio de fluorescéncia polarizada (resultados expressos em milipolarização-mP-), para diferentes concentrações de $\mathrm{THCCOOH}(\mathrm{ng} / \mathrm{ml})$. 
Tabela 20. Concentrações prováveis de THCCOOH nas amostras de usuarios de Cannabis do grupo $I$, obtidas por comparaçào com a cuna-padrão.

\begin{tabular}{lr}
\hline Amostra & $\begin{array}{c}\text { concentração provável } \\
\text { de canabinóides }(\mathrm{ng} / \mathrm{ml})\end{array}$ \\
\hline 1 A & 111,5 \\
1 B & 38,9 \\
2 & 26,4 \\
3 A & 155,3 \\
3 B & 32,1 \\
3 C & 925,5 \\
4 & 455,9 \\
5 & 459,5 \\
6 A & 29,7 \\
6 B & 17,5 \\
6 C & 24,3 \\
7 A & 393,4 \\
7 B & 311,2 \\
8 A & 21,6 \\
8 B & 8,3 \\
9 A & 28,2 \\
9 B & 15,6 \\
10 & 27,1 \\
11 A & 19,0 \\
11 B & 38,3 \\
11 C & 18,1 \\
11 D & 33,1 \\
11 E & 16,3 \\
12 A & 51,2 \\
12 B & 32,4 \\
\hline
\end{tabular}


Tabela 21. Concentrações prováveis de $\mathrm{THCCOOH}$ nas amostras de usuários de Cannabis do grupo II, obtidas por comparação com a curva-padrão.

\begin{tabular}{cc}
\hline Amostra & $\begin{array}{c}\text { concentração provável } \\
\text { de THCCOOH (ng/ml) }\end{array}$ \\
\hline $1 \mathrm{~L}$ & 588,6 \\
$2 \mathrm{~L}$ & 16,8 \\
$3 \mathrm{~L}$ & 20,6 \\
$4 \mathrm{~L}$ & 64,1 \\
$5 \mathrm{~L}$ & 18,0 \\
$6 \mathrm{~L}$ & 17,6 \\
$7 \mathrm{~L}$ & 27,4 \\
$8 \mathrm{~L}$ & 20,0 \\
$9 \mathrm{~L}$ & 27,3 \\
$10 \mathrm{~L}$ & 239,2 \\
$11 \mathrm{~L}$ & 25,6 \\
$12 \mathrm{~L}$ & 32,4 \\
$13 \mathrm{~L}$ & 88,7 \\
$14 \mathrm{~L}$ & 118,2 \\
$15 \mathrm{~L}$ & 33,9 \\
$16 \mathrm{~L}$ & 31,6 \\
$17 \mathrm{~L}$ & 16,7 \\
\hline
\end{tabular}


Tabela 22. Concentrações prováveis de THCCOOH em amostras de usuários de Cannabis do grupo III, obtidas por comparação com a curva-padrão

\begin{tabular}{cc}
\hline Amostra & $\begin{array}{c}\text { Concentração provável } \\
\text { de THCCOOH }(\mathrm{ng} / \mathrm{ml})\end{array}$ \\
\hline $1 \mathrm{~F}$ & 396,5 \\
$2 \mathrm{~F}$ & 40,0 \\
$3 \mathrm{~F}$ & 21,5 \\
$4 \mathrm{~F}$ & 58,9 \\
$5 \mathrm{~F}$ & 82,3 \\
$6 \mathrm{~F}$ & 55,6 \\
$7 \mathrm{~F}$ & 25,5 \\
$8 \mathrm{~F}$ & 16,7 \\
$9 \mathrm{~F}$ & 11,0 \\
$10 \mathrm{~F}$ & 11,4 \\
$11 \mathrm{~F}$ & 18,4 \\
$12 \mathrm{~F}$ & 31,7 \\
\hline
\end{tabular}




\section{DISCUSSÃO}

Desenvolver em nosso país um estudo analítico que envolva drogas de abuso representa mais uma dificuldade, além das que normalmente enfrentamos na pesquisa cientifica.

Pela rigidez de nossa legislação, seria impossivel seguir os mesmos padrões éticos e jurídicos utilizados por pesquisadores em outros paises. No Brasil, não é permitido fornecer substância de uso ilícito, ou mesmo presenciar sua utilização, o que se constituiria em flagrante delito, e diante do qual todo cidadão pode e todo policial deve agir de conformidade com a lei, no sentido de deter o indivíduo infrator.

Por outro lado, o fornecimento de um fluido biológico devidamente identificado pode-se constituir em prova contra o doador, já que o uso de uma substância caracterizada como de uso ilícito constitui crime.

O grande problema ainda é a obtenção de amostras de usuários.

No sentido de contornar este problema, de início, pretendiamos trabalhar junto a clínicas de recuperação de farmacodependentes. Quando do ingresso destes indivíduos na instituição, seria solicitada informação quanto ao uso anterior de Cannabis, e caso a resposta fosse positiva, o individuo seria informado sobre este trabalho cientifico e convidado a participar através da doação de uma amostra.

Todo este trabalho seria realizado pelos funcionários das clínicas, e em nenhum momento a amostra identificada ou o usuário em recuperação conhecido por pessoas não pertencentes ao quadro de funcionários das clínicas.

Porém o pequeno número de amostras obtido dessa maneita e a escassez de informações nos levaram a procurar outras fontes de obtenção de amostras.

Uma segunda opção seria o Laboratório de Análises Toxicológicas (LAT) da FCFUSP. As amostras analisadas por imunoensaio de fluorescência polarizada, com resultado positivo para canabinóides, seriam cedidas para a realização deste trabalho. 
Ainda assim, eram totalmente desconhecidas as informações sobre padrão de uso da droga e último uso antes da coleta de amostra.

Algumas pessoas, entendendo a importância deste trabalho e sensibilizadas com as dificuldades que se vinha tendo com a obtenção de amostras e informações, contactaram terceiros, no sentido de encontrarem usuários que quisessem colaborar com esta pequisa, tendo a garantia de total confidencialidade por parte destas pessoas.

Sendo assim, algumas amostras chegaram, em frascos de vidro sem i.dentificação do doador, numerados aleatoriamente e com informações muito interessantes.

Apesar de não ser possivel garantir a precisão dessas informações, especialmente em relação ao horário das coletas, por se tratar de voluntários, não questionamos a veracidade das informações ou a autenticidade das amostras. As informações disponiveis estão relatadas na tabela 9.

Outra dificuldade encontrada foi o periodo de recebimento das amostras. As do grupo I foram recebidas de novembro de 92 a dezembro de 93. As amostras provenientes do LAT e de uma clínica de recuperação, foram obtidas durante dois anos.

Outro obstáculo a ser vencido foi a obtenção do padrão de $\mathrm{THCCOOH}$. A aquisição dessa substância, encontrada apenas no Exterior, carece de autorização especial para importação, emitida por entidades governamentais. Devido às barreiras burocráticas, leva-se mais tempo para importar esta substância do que o normalmente gasto em procedimentos de importação.

Graças a uma doação da Organização Mundial de Saúde ao LAT é que conseguimos o padrão de $\mathrm{THCCOOH}$ utilizado neste trabalho. A realização da análise toxicológica forense, desta forma, enfrenta muitas restrições em nosso país.

Toda esta dificuldade em obter amostras pode ter sido a causa desta lacuna de conhecimentos em nosso país, que vai desde a correta utilização de técnicas analíticas até a interpretação de resultados. 
Trabalhos anteriores ${ }^{118,120}$ trouxeram uma colaboração importante para os toxicologistas forenses, mas ainda assim faltava estudar uma metodologia que fosse acessivel, de baixo custo e confiável na detecção do uso de Cannabis.

Essa foi a finalidade deste trabalho.

A extensa revisão que realizamos na literatura especializada nos levaram a selecionar o método preconizado por MEATHERALL e GARRIOTT 98 para ser estudado.

Este método recomendava o uso da cromatografia em camada delgada de alta eficiência (CCDAE), uma técnica cujo princípio é relativamente bem conhecido pelos toxicologistas forenses em todo o país, devido a utilização da cromatografia em camada delgada. Os resultados obtidos com a aplicação desse método, demonstrou sua eficácia na detecção do $\mathrm{THCCOOH}$.

Utilizando as condições cromatográficas preconizadas no método de referência, foi alcançada a sensibilidade de 10ng para o padrão de $\mathrm{THCCOOH}$.

No estudo com adicionados, a sensibilidade encontrada foi de $5 \mathrm{ng} / \mathrm{ml}$ utilizando $5 \mathrm{ml}$ de amostra. MEATHERALL e GARRIOTT ${ }^{98}$ relatam sensibilidade de $5 \mathrm{ng} / \mathrm{ml}$ a partir da utilização de $2 \mathrm{ml}$ de amostra. A causa desta diferença de sensibilidade foi, provavelmente, em decorrência do padrão. Na época em que estes testes foram feitos o padrão já apresentava no cromatograma uma pequena mancha secundária que, a partir das informações disponiveis, supomos tratar-se do

$\Delta^{9}$ THC, produto de descarboxilação do $\mathrm{THCCOOH}^{77}$.

Em relação à recuperação, por não haver densitômetro disponível, este estudo não pode ser realizado. Um ensaio de estimativa visual, ainda que de valor subjetivo, poderia ter alguma validade, pelo menos para avaliar os resultados obtidos dentro das nossas condições de trabalho.

Sendo assim, adicionados foram preparados em triplicata e comparados com quantidades conhecidas de $\mathrm{THCCOOH}$ aplicadas diretamente à placa. Os resultados obtidos foram compativeis com a faixa relatada por MEATHERALL (60-82\%), tendendo ao limite inferior para concentrações menores que $20 \mathrm{ng} / \mathrm{ml}$. 
Nos trabalhos consultados, onde a CCDAE foi utilizada, os volumes de amostra eram de $2 \mathrm{ml}^{135,98}$ e $\left.10 \mathrm{~m}\right|^{12,64}$. Como o limite de sensibilidade neste trabalho foi de $5 \mathrm{ng} / \mathrm{ml}$ partindo-se de $5 \mathrm{ml}$ de amostra, passou-se a utilizar este volume de amostra.

Apesar desta diferença de sensibilidade, os resultados que encontramos foram satisfatórios, tendo em vista que a literatura relata que as concentrações normalmente encontradas em usuários ocasionais e pesados variam de $20-500 \mathrm{ng} / \mathrm{m} \mid 99,106$. Além disso, não existe atualmente um consenso em torno do cutoff a ser utilizado na fase de triagem para canabinóides. O National Institute of Drug Abuse (NIDA) estabelece o valor de $100 \mathrm{ng} / \mathrm{ml}$. Entretanto, alguns autores têm recomendado a utilização de um cutoff menor, com base na faixa de concentração relacionada ao uso ocasional. Comercialmente estão disponiveis calibradores com 20,25, 50 e $75 \mathrm{ng} / \mathrm{ml}$, entre os diferentes fabricantes. O mais utilizado tem sido $50 \mathrm{ng} / \mathrm{ml}$.

Para a fase de confirmação, a NIDA estabele um cutoff de $15 \mathrm{ng} / \mathrm{ml}$ para o $\mathrm{THCCOOH}$. Portanto, a sensibilidade de $5 \mathrm{ng} / \mathrm{ml}$ é mais do que suficiente para satisfazer as exigências analíticas dos programas de controle do uso de drogas de abuso, e o volume de amostra de $5 \mathrm{ml}$ é um volume facilmente obtido.

$\mathrm{Na}$ fase de preparação da amostra, a grande maioria dos autores não dispensam - uso de hidrólise, especialmente a alcalina. Isto se deve às características de eliminação do $\mathrm{THCCOOH}$ do organismo. A concentração de sua forma livre na urina é pequena e tende a diminuir a medida que a eliminação prossegue até desaparecer completamente cerca de $8 \mathrm{~h}$ após a exposição, sendo que a forma conjugada é a única encontrada após este período 79 . No trabalho, o aumento no volume de amostra foi acompanhado, então, por um aumento proporcional no volume de álcali utilizado no passo de hidrólise. Isto porque os autores que trabalharam com $\mathrm{NaOH}$ utilizaram um volume de álcali correspondente a 10\% do volume de amostra105,135,98,90,144.

As condições ideais para a hidrólise alcalina com $\mathrm{NaOH} 6 \mathrm{M}$, estudadas por VINSON e LOPATOFSKY135 foram seguidas por MEATHERALL98, que trabalhou com 
$\mathrm{NaOH} 1 \mathrm{~N}$. Estas condições foram adotadas inicialmente neste trabalho e basicamente envolvem submeter a amostra à temperatura de $50-60^{\circ} \mathrm{C}$ durante 15 minutos.

A grande maioria dos trabalhos realiza a extração do THCCOOH da urina em meio ácido, $\mathrm{pH} 4105,50,97,135,98,90,144,45$. Em relação ao aumento do volume de amostra de 2 para $5 \mathrm{ml}$, e do volume do álcali para $0,5 \mathrm{ml}$, não houve necessidade de aumento proporcional do $\mathrm{HCl} 1 \mathrm{~N}$ utilizado por MEATHERALL na fase de acidificaçäo da amostra, pois o $\mathrm{pH}$ continuava inferior a 4. Quando utilizado o método $\mathrm{B}$, a acidificação da amostra era feita com acido acético glacial, pois este era o ácido recomendado pelos autores 97,86 , além do que bastava um pequeno volume, cerca de $1,4 \mathrm{ml}$, para produzir o $\mathrm{pH}$ desejado (pH 4).

Para a extração líquido/líquido de canabinóides, vários solventes são citados na literatura. Entre os mais citados está o hexano 81,98,15 e a mistura hexano:acetato de etila $7: 16,23,105,97,10$. Os autores que trabalham com hexano relatam que ele produz extratos com menos interferentes, sem necessidade de purificação posterior, o que permite sua aplicação direta em cromatografia em fase gasosa.

Ambos os solventes foram estudados, e a substituiçao do hexano por hexano:acetato de etila não produziu aumento significativo na intensidade das bandas de $\mathrm{THCCOOH}$. Pelo contrário, a presença de um segundo solvente mais polar produziu resíduos mais "sujos", e para algumas amostras isto chegou a interferir na visualização das bandas na CCDAE. Esta observação está de acordo com o verificado por MEATHERALL, que relata o arraste de impurezas feito pela mistura de solventes e sua influência sobre a deteç̧ão do THCCOOH.

Um solvente alternativo, o ciclohexano, mostrou ser equiparável ao n-hexano quando utilizado na extração de amostras de usuários. Ele é citado na literatura misturado com acetato de etila na proporção $96: 4$ 77. Contudo como o efeito da adição de solventes mais polares já era conhecido, ele foi utilizado sozinho.

Embora tenha sido utilizado um volume de amostra maior que o recomendado no método de MEATHERALL e GARRIOTT, isto é, $5 \mathrm{ml}$, o volume do solvente extrator não foi 
alterado. A emulsão formada na fase de agitação mecânica é facilmente quebrada na etapa de centrifugação, usando $1000 \mathrm{~g}$ por $5 \mathrm{~min}$. As amostras que produziram emulsão mais persistente foram tratadas como indicado no método original, ou seja, a emulsão foi separada, acrescida de algumas gotas de n-butanol e novamente centrifugada-. A parte superior que contém o hexano é retirada com auxilio de pipeta pasteur.

Alguns problemas de recuperação foram observados em resíduos que, apesar de virtualmente secos, após reconstituição pela mistura solvente clorofórmio:metanol 3:1, apresentavam dificuldades na transferência para placa, como se contivessem água residual. Neste caso, duas importantes observações precisam ser feitas. Primeiramente, muita atenção tem que ser dada à possivel transferência de emulsão residual no processo de separação das fases. Uma gota de emulsão pode gerar um pequeno resíduo denso que, mesmo depois de seco, ao ser ressuspendido, atrapalha a transferência de material para a placa.

Outro aspecto a ser levado em consideração é o processo de evaporação do solvente. A citação de MEATHERALL quanto à utilização de corrente de ar seco nos levou a testar a utilização de uma simples corrente de ar obtida com o uso de um secador de cabelo. Uma corrente a frio e suave era suficiente para evaporar o hexano a temperatura ambiente, sem maiores problemas.

O processo, contudo, era moroso, e em dias frios ou úmidos ocorria algumas vezes condensação de água nas paredes dos recipientes que continham o resíduo.

A conjugação do secador de cabelo com um banho-maria $\left(50^{\circ} \mathrm{C}\right)$ minimizou o problema de condensação de água, entretanto, o processo de evaporação continuava lento e preocupava o tempo em que o residuo permanecia sob ação do calor, visto como este é um fator deletério para o $\mathrm{THCCOOH}$. Como Meatherall indicava o uso de corrente de ar seco, passou-se a evaporar o solvente sob corrente de nitrogênio, pois este era tratado com sílica gel antes de chegar à amostra.

Mesmo assim, não foi possivel dispensar o uso de banho-maria, devido ao problema de condensação de água nas paredes dos recipientes. Por precaução, a 
temperatura de $45-50^{\circ} \mathrm{C}$ nunca foi ultrapassada. Ainda que o resíduo no fundo do recipiente esteja seco, deve-se observar suas bordas superiores, para não ocorrer que, no processo de ressuspensão, alguma gotícula de água seja arrastada das paredes laterais para o fundo do recipiente. Todo resíduo de difícil transferência gerava banda mais difusa, e em algumas amostras de usuários ocasionais não foi possivel visualizar a banda referente ao $\mathrm{THCCOOH}$.

Alguns trabalhos mencionam a necessidade de se trabalhar com vidraria silanizada. Segundo MEATHERALL ${ }^{98}$, vários solventes são capazes de recuperar todo 0 $\mathrm{THCCOOH}$ do resíduo se a vidraria for silanizada. Caso não seja silanizada, somente álcoois ou misturas de clorofórmio ou diclorometano que contenham no minimo $5 \%$ de etanol ou metanol são capazes de recuperar todo o $\mathrm{THCCOOH}$. Como silanizar o material pode representar uma dificuldade e um custo a mais, adotamos como solvente para ressuspensão de resíduo a mistura clorofórmio:metanol 3:1, utilizada por MEATHERALL ${ }^{98}$. Os sistemas solventes indicados para fase móvel nos trabalhos com CCDAE são misturas que envolvem, geralmente, n-heptano, ácido acético glacial e um terceiro solvente que pode ser acetona ${ }^{12,64}$, éter ${ }^{135}$ ou n-butanol98. MEATHERALL e GARRIOTT utilizaram o n-butanol. Os valores de hRf obtidos com a utilização destas fases móveis são próximos: $38^{12,64}, 32-34^{135}$ e $40^{98}$.

A saturação da fase móvel parece ocorrer dentro de 15 minutos. Tempos maiores não oferecem nenhuma vantagem. Em nossa experiência, nunca foi possivel obter bons cromatogramas desenvolvendo 2 ou 3 placas simultaneamente. Nem mesmo retirando uma e colocando outra logo de imediato. O front do solvente apresenta irregularidades, e problemas típicos de insaturação ocorrem freqüentemente. Melhores resultados são obtidos com fase móvel recentemente preparada e eluição de uma placa por vez. Caso seja necessário eluir outra placa, deve-se novamente esperar 10-15 minutos antes de desenvolver o segundo cromatograma, para que novamente se alcance a saturação da cuba. 
Após o desenvolvimento, as placas eram deixadas na capela, a temperatura ambiente, por 5-10 minutos; tempo suficiente para evaporação do solvente.

A reação colorimétrica mais especifica e a preferida para identificação de canabinóides por CCD e CCDAE envolve a reação de canabinóides com o corante Fast Blue. Três variações deste corante são mencionadas na literatura: o Fast Blue $B$ 12,64,107,78, o Fast Blue RR 77,90 e o Fast Blue $B B^{98,135,131,63,96,86}$. Este último apresenta vantagens sobre os dois primeiros, como já citado anteriormente, e foi a escolha feita para este trabalho.

Como considerado anteriormente, nos aspectos analíticos, a basicidade do cromógeno é importante para o desenvolvimento da cor. A dietilamina possui vantagens já mencionadas anteriormente em relação a outros álcalis e tem sido muito citada na literatura131,98,96,86. Ela foi o álcali escolhido e sua aplicação segue as recomendações feitas por MEATHERALL, ou seja, ela deve ser aplicada antes e depois do Fast Blue BB.

Depois de secos, os cromatogramas são nebulizados com dietilamina $e, \operatorname{logo} a$ seguir, a solução de Fast Blue BB é aplicada. No preparo da solução de Fast Blue BB $0,1 \%$, devido a dificuldades encontradas na sua dissolução, o sal é inicialmente dissolvido em $1 \mathrm{ml}$ de metanol e completado volume para $10 \mathrm{ml}$ com água destilada. Isto acelera a dissolução do corante.

Após 5-10 minutos as placas eram observadas e, depois de totalmente secas, eram envolvidas por filme plástico transparente, e guardadas em caixa de isopor, ao abrigo da luz. Nestas condições observamos que os cromatogramas eram estáveis por vários meses. Alguns permanecem com a cor original mesmo depois de 2 anos. Outros adquiriram um fundo mais escuro, alaranjado. Segundo relatado por alguns autores $\mathbf{1 3 5 , 9 8}$ isto se deve à aplicação de soluções mais concentradas de Fast Blue BB.

Esta durabilidade dos cromatogramas também foi mencionada por MEATHERALL ${ }^{98}$, VINSON135 e em uma publicação da Organização Mundial de Saúde ${ }^{109}$, exceto que aqui os cromatogramas não foram guardados no freezer, e sim, em caixas de isopor. 
Isto constitui-se em vantagem, principalmente para a análise de caráter forense, sendo o próprio cromatograma uma forma de documentar os resultados para consulta posterior.

Em relação ao tempo máximo que se pode esperar entre a aplicação do resíduo e o desenvolvimento do cromatograma ( 2 horas), e entre o desenvolvimento e a revelação (2 horas), sempre foram respeitados esses limites durante este trabalho. Quando o padrão foi aplicado à placa e, na manhã seguinte, ela foi revelada, não visualizou-se o padrão de $\mathrm{THCCOOH}$.

Os resultados obtidos mostram boa reprodutibilidade nos valores de hRf. A análise inter-série de 16 cromatogramas produziu um valor médio de hRf igual a $34 \mathrm{com}$ desvio-padrão $=3$. Excetuando-se alguns problemas devido à insaturação, não foi observada variação significativa no hRf para uma mesma placa.

MEATHERALL ${ }^{98}$ se refere, não ao hRf, mas à distância de migração a partir do ponto de aplicação da amostra, para um percurso de $7,5 \mathrm{~cm}$. O autor relata um valor médio de $3 \mathrm{~cm}$ com variações dia a dia de mais ou menos $0,5 \mathrm{~cm}$. Isto equivaleria a falar de um hRf médio $=40$. Ele preferiu trabalhar com $\mathrm{Rf}$ relativo e usar o canabinol como referência. Como não havia disponibilidade deste canabinóide em nosso laboratório, trabalhamos apenas com o $\mathrm{THCCOOH}$.

Em relação à influência das substâncias normalmente presentes na urina, não observamos alteração o hRf do $\mathrm{THCCOOH}$. Em todos os cromatogramas o hRf das amostras coincide com o hRf do padrão. Segundo MEATHERALL, esta qualidade é atribuida ao solvente extrator, no caso, o hexano, que fornece extratos limpos. O mesmo não é observado quando se trabalha com outros solventes.

A literatura cita, pelo menos, 4 trabalhos onde foi pesquisada a interferência de outras substâncias na identificação de canabinóides por cromatografia em camada delgada77,86,47,63 e o próprio Meatherall testou a interferência de 118 fármacos e produtos de biotransformação no método proposto, com resultados negativos. 
A esse método de MEATHERALL ${ }^{98}$, cuja única alteração importante foi em relação ao volume de amostra, chamamos de método A. Por este método, foram analisadas as amostras de usuários do grupo I, primeiro grupo de amostras disponivel para estudo, tendo em vista que seria impossível estudar a hidrólise através de adicionados de $\mathrm{THCCOOH}$. Nesse estudo, era sempre realizada, em paralelo, a análise de um branco e de um adicionado.

Neste primeiro grupo, doze usuários participaram doando amostras $(n=25)$. Segundo a classificação de MULÉ e cols ${ }^{106}$, três eram usuários "pesados"(uso de um ou mais cigarros de Cannabis por dia); um era uruário moderado ( uso de 2 a 3 cigarros de Cannabis por semana); e cinco eram usuários ocasionais ( uso de um cigarro de Cannabis por semana ou menos). Os três usuários restantes não informaram seu padrão de uso.

O conhecimento do padrão de uso é importante porque existe uma correlação direta entre freqüência de uso e periodo de detecção de canabinóides na urina. O efeito acumulativo do THC no organismo humano, devido ao uso repetido de Cannabis, e sua liberação lenta com conseqüente biotransformação ${ }^{71}$, explica as altas concentrações de canabinóides encontradas na urina de usuários "pesados", por muitos dias após uso de Cannabis, e resultados positivos no exame de urina por mais de 21 dias após o último uso 37 .

Em 21 das 25 amostras de usuários foi observada mancha em formato de banda, da mesma cor e hRf do padrão de $\mathrm{THCCOOH}$. Somente 4 amostras passaram como negativas por esta metodologia. Duas delas foram colhidas uma hora após o indivíduo fumar meio cigarro de Cannabis: considerando que se tratava de usuário ocasional, não era de se esperar resultado positivo, já que neste período apenas se inicia o aparecimento do $\mathrm{THCCOOH}$ na urina ${ }^{8}$. No usuário 7, um usuário "pesado", a quantidade de THCCOOH encontrada reflete, provavelmente, exposições anteriores, já que a amostra também foi colhida uma hora após fumar um cigarro. As outras duas amostras (11E e 8B) estavam, supostamente, no limite de sensibilidade do método, 
pois análises repetidas ora davam resultado levemente positivo, oram davam negativo. Este fato fortaleceu ainda mais a determinação de trabalharmos com $5 \mathrm{ml}$ de amostra, tendo em vista que uma destas amostras tinha sido colhida 72 horas após a utilização de um cigarro de Cannabis por um usuário ocasional.

Pela observação dos resultados obtidos, as bandas de $\mathrm{THCCOOH}$ eram bem mais evidentes nos usuários pesados, com dimensões comparáveis às produzidas por quantidades maiores que $200 \mathrm{ng}$ de $\mathrm{THCCOOH}$. Em usuários leves e moderados, essas bandas foram visualmente comparáveis a quantidades entre 20-100ng de THCCOOH.

Nas condiçōes em que este trabalho foi desenvolvido, foi possivel detectar a presença de $\mathrm{THCCOOH}$ na urina de um usuário ocasional até 72 horas após a utilização de um cigarro de Cannabis.

Um usuário do grupo I, de padrão de uso ocasional (usuário 11), foi o único a fornecer amostras em horários regulares. Da primeira coleta, 5 horas após o uso de um cigarro, até a última, 72 horas após a exposição, obteve-se resultados positivos.

Nas primeiras 24 horas observa-se quantidade maior de $\mathrm{THCCOOH}$ do que nas coletas subsequentes ( 48 e $72 \mathrm{~h}$ ). Os mesmos resultados foram observados com 0 usuário número 6.

Estes resultados mostram uma excreção urinária de maiores concentrações de THCCOOH nas primeiras 24 horas. Isto está de acordo com os resultados obtidos por JOHANSSON e cols ${ }^{71}$ para usuários ocasionais.

Tendo em vista citações na literatura de metodologias que não envolviam a etapa de hidrólise ${ }^{136,108}$, foi experimentada a extração com éter etílico em pH 4 e a extração com hexano:isobutanol 9:1 em pH levemente ácido (adição de tampão fosfato $0,1 \mathrm{M}$ pH 6). Com amostras de usuários analisadas por estas metodologias não foram obtidos bons resultados, com queda de rendimento afetando principalmente as amostras de usuários ocasionais.

Consideramos, então, a hidrólise, uma etapa indispensável no processo analítico para detecção de THCCOOH em urina de usuários leves e moderados. Nos usuários 
pesados existe uma quantidade maior de $\mathrm{THCCOOH}$ livre $^{3}$, o que pode explicar 0 prejuizo menor causado pela ausência da etapa de hidrólise

Um outro estudo desenvolvido foi verificar a possibilidade de realização da hidrólise do $\mathrm{THCCOOH}$-conjugado à.temperatura ambiente, como relatado por $\mathrm{KING}^{86} \mathrm{e}$ McCURDY97. Os autores usam, como álcali, o KOH 11,8N, e relataram que a hidrólise é completa após 5 minutos à temperatura ambiente.

O tempo necessário para a hidrólise foi verificado em duas amostras de usuários ocasionais. Usuários "pesados" não foram utilizados porque, como visto anteriormente, possuem maior concentração da forma livre.

Tempos de 5 e 15 minutos foram utilizados para $5 \mathrm{ml}$ de amostra e comparados ao método de MEATHERALL. Não foi observada diferença significativa em relação ao tempo de hidrólise. A hidrólise era eficaz 5 minutos após a adição de $0,5 \mathrm{ml}$ de $\mathrm{KOH}$ $11.8 \mathrm{~N}$ ( $10 \%$ do volume de amostra). A esta modificação no processo de hidrólise chamamos de método de MEATHERALL modificado ou método $B$.

Para verificar o impacto da redução do volume de amostra para $3 \mathrm{ml}$ sobre os resultados nos três diferentes padrões de uso, duas amostras de usuários ocasionais (24 e 48 horas após a utilização de um cigarro de Cannabis) foram inicialmente utilizadas.

Para estes usuários, não foi verificada nenhuma diferença em termos qualitativos quando se parte de $5 \mathrm{ml}$ ou $3 \mathrm{ml}$ de amostra. O resultado continuava positivo.

Contudo, quando todas as amostras do grupo I foram analisadas pelo método de MEATHERALL e GARRIOTT modificado (método B) a partir de $3 \mathrm{ml}$ de amostra, uma diferença para menos foi observada para algumas amostras (6A, 10, 11A e 11B), e uma amostra positiva apareceu como negativa ( 2).

A partir desses resultados, optamos por trabalhar com $5 \mathrm{ml}$ de amostra, e as amostras de usuários, que chegaram após esta etapa do trabalho, passaram a ser analisadas pelo método $B$, por ser mais rápido, simples e não envolver utilização de calor. 
As amostras fornecidas pelo LAT foram analisadas pelo método B. Todas as amostras $(n=17)$ apresentaram resultados positivos por imunoensaio de fluorescência polarizada e por CCDAE (método A), na época em que chegaram ao laboratório.

Pela intensidade das manchas obtidas após análise pelo método $B$, foi possível concluir que pelo menos duas delas eram de usuários "pesados" (1L e 10L), e mesmo após dois anos no freezer, acondicionadas em frascos plásticos, continuavam fornecendo resultado positivo. Seis amostras deram resultado negativo.

No estudo destes resultados discordantes, deve-se levar em conta a instabilidade do $\mathrm{THCCOOH}$ em urinas estocadas por longos periodos, mesmo a temperaturas menores que $0^{\circ} \mathrm{C}$.

PAUL e cols 111 relatam perda de $11 \%$ nos níveis de THCCOOH após 45 dias de congelamento das amostras. KING e cols ${ }^{86}$ observaram que de 107 amostras na faixa de $20-185 \mathrm{ng} / \mathrm{ml}$, 11 ficaram abaixo de $20 \mathrm{ng} / \mathrm{ml}$ após 18 meses de congelamento.

Das amostras enviadas pela clínica de recuperação de farmacodependentes $(n=12), 7$ eram de indivíduos com indicação de uso de Cannabis, e 5 eram de individuos suspeitos de uso de alguma droga de abuso. Nos primeiros 7 indivíduos obteve-se resultado positivo; dos outros 5 , três foram negativos. Neste caso, o resultado negativo pode significar que a droga utilizada não foi a Cannabis.

Alguns autores citam que a hidrólise feita com $\mathrm{KOH}$ gera extratos mais limpos do que a produzida com $\mathrm{NaOH}$. Ainda que isto tenha sido verificado por alguns autores em relação à cromatografia gasosa ${ }^{45}$, não foi observado neste trabalho qualquer influência em relação à CCDAE.

O imunoensaio de fluorescência polarizada (FPIA) é técnica recentemente introduzida no mercado para análise de drogas de abuso em urina. Há pouca literatura disponivel e, mesmo assim, os trabalhos que existem foram feitos em outro tipo de equipamento, diferente do utilizado neste trabalho. Quanto a este, não haviam citações de seu emprego nos trabalhos consultados durante a revisão bibliográfica. Através de 
contato com a empresa fabricante, tivemos acesso aos dois únicos trabalhos 31,76 realizados; isto já na fase final deste trabalho.

Por ser técnica pouco utilizada em nosso país, havia a necessidade de estudá-la em seus aspectos teórico-práticos, principalmente para estabelecer os critérios necessários à boa interpretação dos resultados. Por isso, foi incluido neste trabalho um capítulo abordando a teoria do método e, na parte prática, um trabalho mais elaborado do que o originalmente pensado.

Mesmo existindo uma correspondência entre concentração e o resultado expresso em milipolarização (mP), o que permitiu o emprego desta técnica em controle terapêutico, o uso do FPIA para análise de drogas de abuso é primordialmente qualitativo, porquanto os resultados são emitidos não em valor de concentração e, sim , como positivos ou negativos.

As amostras de usuários do grupo I, submetidas ao FPIA no "cutoff" de 50ng/ml, apresentaram resultado negativo para várias amostras com resultado positivo por CCDAE. Na tentativa de melhor compreender esses resultados, foi elaborado um estudo com a construção de uma curva-padrão, para verificar a relação entre concentração e polarização de fluorescência. Dessa maneira, poderiamos conhecer o teor provável de canabinóides que estas amostras possuiam.

Uma das dificuldades em interpretar resultados oriundos de ensaio imunológico se deve às características de biotransformação do $\Delta^{9}-T H C$. Enquanto os controles e calibradores possuem apenas o $\mathrm{THCCOOH}$ adicionado a um "pool" de urinas, uma amostra de usuários conterá vários canabinóides. Acrescente-se a isto a variação individual observada no processo de biotransformação e as diferentes proporções encontradas dia a dia na composição dos canabinóides urinários.

Esperam-se reações cruzadas, ainda que o fabricante relate apenas reatividade cruzada com o $\triangle 8$-THCCOOH. Por isso, os resultados obtidos com a curva-padrão não podem ser extrapolados para as amostras, senão com certa reserva. 
Na construção da curva-padrão, foram utilizados os controles ( dau-TRAK® Multicontrôle) fornecidos pelo fabricante:

Pelo menos, duas concentrações diferentes na faixa de controle baixo e alto foram utilizadas, e três em torno do valor de"cutoff",todas em triplicata. Como o uso de pipeta automática não forneceu resultados com boa correlação, passou-se a utilizar micro-seringa.

A curva-padrão, típica de ensaios imunológicos, foi obtida neste trabalho, com configuração convexa, bem como a inclinação descendente, devido à relação inversamente proporcional entre polarização e concentração. Com esta alteração, foi obtido um coeficiente de correlação $\cong 0,99$.

O coeficiente de correlação obtido nos encorajou a utilizar a equação gerada no modelo de regressão linear, para verificar a concentração provável de canabinóides nas amostras.

Pelos resultados obtidos, as amostras negativas no "cutoff" de $50 \mathrm{ng} / \mathrm{ml}$ possuiam concentrações de canabinóides, na sua maioria, entre $20-50 \mathrm{ng} / \mathrm{ml}$. O que explicaria os resultados negativos obtidos para amostras de usuários neste valor de "cutoff".

A utilização de um "cutoff" de $20 \mathrm{ng} / \mathrm{ml}$ poderia produzir resultados positivos para estas amostras. Neste momento, uma nova remessa de reagentes teria que ser utilizada na análise das amostras. Como a nova calibração apresentou um valor menor de milipolarização que a anterior, optou-se por construir uma segunda curva-padrão com este novo reagente e reanalizar as amostras no "cutoff'de $20 \mathrm{ng} / \mathrm{ml}$.

Para esta segunda curva-padrão, observou-se ligeira queda nos valores de polarização proporcional a todas as concentrações. Desta forma, as amostras analisadas por esta remessa de reagentes tiveram seus resultados correlacionados com a segunda curva-padrão, e não com a primeira.

A análise por FPIA das amostras de usuários, como era de se esperar, apresentou resultados positivos no "cutoff" de $20 \mathrm{ng} / \mathrm{ml}$, principalmente para os usuários 
ocasionais. Alguns usuários ainda demonstraram possuir concentrações menores que 20ng/mil.

As amostras dos grupos $\Pi$ e $\Pi$ também foram analisadas no"cutoff" de $20 \mathrm{ng} / \mathrm{ml}$.

Nas 17 amostras fornecidas pelo LAT, 10 foram positivas; 6 , negativas; e uma foi negativa porém próxima ao valor de "cutoff". Estas amostras tinham sido analisadas por FPIA no "cutoff" de $100 \mathrm{ng} / \mathrm{ml}$.

Nas amostras 1F a 7F, de indivíduos com indicação de uso de Cannabis, apenas duas amostras deram negativo, porém com sinal de advertência do aparelho de que se tratava de valor próximo ao "cutoff". Nas amostras onde havia suspeita de uso de alguma droga de abuso, amostras $8 \mathrm{~F}$ a $12 \mathrm{~F}$, apenas uma foi positva; três foram negativas e uma foi negativa, porém próxima ao valor de "cutoff".

Conforme relatado pelo fabricante, espera-se uma variação de mais ou menos 5 milipolarizações (mP) em leituras repetidas (imprecisão). Durante os meses em que o aparelho foi utilizado, observaram-se variações de leitura dentro desta faixa de mais ou menos $5 \mathrm{mP}$. KÄFERSTEIN e STICHT76 estudaram a precisão no Vitalab Eclairß, com reagentes dau-TRAK® para canabinóides, e relatam um c.v.max de 2,2\%. O mesmo autor relata que nenhum resultado cujo valor esteja próximo ao cutoff deve ser desprezado, mormente em relação aos canabinóides.

Em nosso trabalho, observamos que a pipetagem é crítica, devido à alta sensibilidade do método. A utilização de micro-seringa para análises repetidas de uma mesma amostra revelou uma variação de resultados dentro da faixa de imprecisão do método. $\mathrm{O}$ uso de pipetas automáticas de baixa qualidade produziu variações de até $40 \%$ nos valores de MP para uma mesma amostra.

É por esta razão que os resultados obtidos com a curva-padrão para as amostras selecionadas nesse trabalho, mencionam concentração provável de $\mathrm{THCCOOH}$, e não um valor absoluto. Mais ainda, pela própria característica da curva, muito cuidado tem que ser tomado na estimativa de concentrações urinárias de canabinóides para individuos que fazem uso intenso da Cannabis. Esses usuários geralmente possuem 
concentrações maiores que $100 \mathrm{ng} / \mathrm{ml}$ e, nesta região da curva, pequenas variações na milipolarização causam grandes variações nos resultados.

O estudo realizado com a curva-padrão permitiu uma melhor avaliação dos resultados obtidos com a análise de amostras de usuários. Foi possível verificar que os niveis de canabinóides em usuários ocasionais e moderados estão na faixa de 20$100 \mathrm{ng} / \mathrm{ml}$, sendo que uma fração considerável permanece abaixo de $50 \mathrm{ng} / \mathrm{ml}$. Esta faixa de concentração para usuários ocasionais e moderados também foi reportada por JONES 75 e MULÉ106.

DEGEL e cols ${ }^{31}$ citam em seu trabalho que o valor de "cutoff" igual a $100 \mathrm{ng} / \mathrm{ml}$ pode ser utilizado em situações que envolvem a clínica toxicológica, mas é muito alto para a análise com fins forenses. Mesmo não tendo um número muito elevado de amostras, os resultados obtidos neste trabalho corroboram esta conclusão.

Alguns autores consideram arriscado usar um "cutoff"de $20 \mathrm{ng} / \mathrm{ml}$, devido ao problema da inalação passiva. Contudo, em experimentos realizados com inalação passiva, mesmo em condições extremas de exposição, em níveis maiores dos que os encontrados em situações normais, as concentrações de canabinóides na urina foram inferiores a $20 \mathrm{ng} / \mathrm{m}^{26,94}$. Em condições experimentais mais próximas das situações reais conhecidas, estes níveis foram inferiores a $6 \mathrm{ng} / \mathrm{m} / \mathbf{1 0 4 , 1 0 6}$.

A seleção da concentração de "cutoff" não pode ser feita com base na sensibilidade do método ${ }^{43}$, como também não pode ser confundida com sensibilidade ${ }^{43}$. Mesmo trabalhando com $20 \mathrm{ng} / \mathrm{ml}$, ainda estamos acima da sensiblidade do método $(5 \mathrm{ng} / \mathrm{ml})$.

Ainda que isso implique um aumento do percentual de resultados não confirmados pelo CG/MS ou pela CCDAE, e considerando esta técnica como técnica de triagem, a não detecção de um provável usuário é, no mínimo, pouco recomendável em um programa direcionado a este propósito ${ }^{141}$.

A comparação entre os resultados obtidos com a análise de urina de usuários de Cannabis por FPIA e por CCDAE, levantou questões interessantes. 
Nas amostras do grupo I, houve excelente correlação entre os resultados obtidos por ambas as técnicas para os usuários "pesados". De acordo com a curva-padrão, estas amostras teriam teores elevados de canabinóides ( mais de $300 \mathrm{ng} / \mathrm{ml}$ ).

O usuário moderado apresentou concentrações urinárias de canabinóides semelhantes aos usuários ocasionais, isto é, na faixa de $20-50 \mathrm{ng} / \mathrm{ml}$, com resultados imunológicos variando.entre negativo, negativo*, positivo* e positivo ("cutoff'de $20 \mathrm{ng} / \mathrm{ml})$.

Algumas amostras negativas no FPIA foram positivas por $\mathrm{CCDAE}$ ( $6 \mathrm{~B}, 6 \mathrm{C}, 8 \mathrm{~A}$,

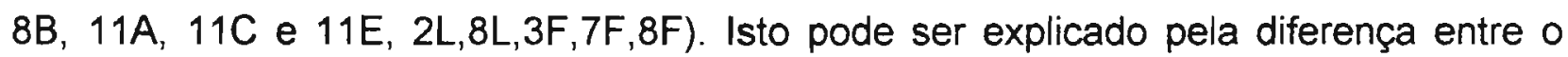
"Cutoff" do método imunológico ( $20 \mathrm{ng} / \mathrm{ml}$ ) e a sensibilidade alcançada neste método em $\operatorname{CCDAE}(5 \mathrm{ng} / \mathrm{ml})$.

Três amostras positivas no FPIA foram negativas na $\operatorname{CCDAE}(2,9 \mathrm{~A}, 16 \mathrm{~L}$,$) . A$ primeira vista poderíamos dizer que se tratam de falsos-positivos. Contudo as duas primeiras eram amostras de indivíduos que se declararam usuários de Cannabis, e a última havia dado positivo por FPIA e CCDAE quando de sua chegada ao LAT há dois anos. A utilização da curva-padrão mostra concentração provável de canabinóides na faixa de $20-30 \mathrm{ng} / \mathrm{ml}$.

JOERN 67 relata que nem todos os resultados positivos de um ensaio imunológico serão efetivamente confirmados, mesmo não se tratando de um falso positivo. Isto se deve às características da biotransformacão. Ele observou que a proporção de $\mathrm{THCCOOH}$ varia em relação aos outros canabinóides, de modo que um teor relativamente elevado de canabinóides pode, em dado momento, corresponder a um baixo teor de $\mathrm{THCCOOH}$.

Para uma das amostras fornecidas pelo LAT (amostra 16L), é importante que se leve em consideração a degradação do $\cdot \mathrm{THCCOOH}$ ocorrida durante o longo armazenamento da amostra. 
Vale ressaltar que na CCDAE pesquisamos apenas um canabinóide, o THCCOOH, enquanto no ensaio imunológico, dependendo das características do anticorpo, um grupo de canabinóides estruturalmente relacionados contribuem com o resultado.

Apesar do fabricante dos reagentes utilizados neste trabaiho relatarem reatividade cruzada apenas $\mathrm{Com} 0 \triangle^{8}-\mathrm{THCCOOH}$, os resultados obtidos mostram que um percentual maior de reatividade cruzada provavelmente existe com outros canabinóides.

Em termos qualitativos, os resultados da CCDAE se correlacionam melhor com os resultados negativos obtidos por FPIA no "cutoff" de $20 \mathrm{ng} / \mathrm{ml}$ do que no de $50 \mathrm{ng} / \mathrm{ml}$, significando que muitas amostras que passam como negativas pelo "cutoff'de $50 \mathrm{ng} / \mathrm{ml}$ poderiam ser positivas na CCDAE.

Em relação aos resultados positivos por FPIA, a literatura relata que quanto maior - "cutoff"vitilizado, maior será a correlação existente entre o método imunológico e o método cromatográfico $\mathbf{7 2 , 4 8 , 4 9}$. Isto também foi visto neste trabalho para as amostras de usuários "pesados", geralmente contendo mais de $100 \mathrm{ng} / \mathrm{ml}$ de canabinóides.

Assim como relatado por outros autores $131,135,12,31$, a CCDAE pode ser útil para confirmar os resultados de um imunoensaio. Devido ao índice de falsos positivos apresentado pelos métodos imunológicos, a análise prévia por CCDAE antes da confirmação por CG/MS pode ser uma maneira viável de se diminuírem os custos analíticos, quando se trabalha com uma grande quantidade de amostras.

Quanto ao número de amostras que podem ser analisadas por placa de CCDAE, as placas $10 \times 10 \mathrm{~cm}$ comportam até 9 amostras, o padrão, um branco ou adicionado. Contudo, estas placas podem ser cortadas ao meio, sem que isto traga qualquer prejuizo às condições cromatográficas, permitindo a análise de um número menor de amostras.

No caso da análise forense, por ser irregular o fluxo de amostras de urina para detecção de drogas de abuso, visto que isso depende muito da prisão em flagrante e da cooperação do individuo detido no fornecimento da amostra como prova, o uso de ensaios imunológicos pode ser dificultado devido a validade limitada dos reagentes após 
a primeira utilização. Juntar amostras até um número de 20 ou 30 é inviável, pois atrasaria em muito todo andamento do processo penal.

Um resultado positivo por método imunológico necessitará obrigatoriamente de ser confirmado por um outro método com principio analítico diferente. O principal método para confirmação do $\mathrm{THCCOOH}$ tem sido o $\mathrm{CG} / \mathrm{MS}$. Entretanto, devido ao alto custo do equipamento e dos reagentes necesários à sua operação, ainda não é possivel, infelizmente, utilizarmos o CG/MS nas análises de rotina em nossos serviços forenses.

Têm-se estudado outros métodos cromtográficos para a fase de confirmação 64,47,131,97,42,90,107, incluindo a CCDAE 131,135,12,31.

Pelos resultados obtidos, o método estudado é perfeitamente aplicável à análise forense, por sua sensibilidade e especificidade adequadas a detecção de usuários ocasionais mesmo após 3 dias de utilização de apenas 1 cigarro de Cannabis.

Nenhuma das amostras utilizadas como controle (branco de referência) forneceu resultados semelhantes ao padrão de $\mathrm{THCCOOH}$, o que nos permite relatar, até o momento, que se trata de um método com especificidade adequada, podendo ser empregado como método analítico confiável para detecção de usuários de Cannabis em nossos serviços de toxicologia forense. 


\section{CONCLUSÕES}

A partir dos resultados obtidos no trabalho experimental realizado, podemos concluir:

- A cromatografia em camada delgada de alta eficiência (CCDAE), nas condições estudadas, possui sensibilidade para detecção de 10 ng de $\mathrm{THCCOOH}$.

- O volume adequado de amostra para identificação de usuários de Cannabis é de $5 \mathrm{ml}$.

- A sensibilidade verificada no estudo com adicionados foi de $5 \mathrm{ng} / \mathrm{ml}$ para $5 \mathrm{ml}$ de amostra.

- Amostras de usuários de Cannabis apresentaram resultados semelhantes aos observados no padrão de $\mathrm{THCCOOH}$.

- Pelo método estudado, foi possível detectar $\mathrm{OTHCCOOH}$ em urina de usuários de Cannabis até 72 horas após a utilização de um único cigarro.

- Na cromatografia em camada delgada de alta eficiência não foram observados resultados semelhantes aos obtidos com o padrão de $\mathrm{THCCOOH}$ em nenhuma das amostras utilizadas como branco de referência.

- Amostras de usuários ocasionais foram negativas no FPIA com a utilização do "cutoff" de $50 \mathrm{ng} / \mathrm{ml}$.

- No estudo comparativo dos resultados obtidos nas duas técnicas, foi verificada uma correspondência de 100\% nas amostras de usuários com padrão de uso intenso.

- No estudo comparativo dos resultados obtidos nas duas técricas, não foi verificada boa correspondência nas amostras de usuários com padrão de uso moderado e ocasional. 


\section{REFERÊNCIAS BIBLIOGRÁFICAS*}

001.ABERCROMBIE, M.L., JEWELL, J.S. Evaluation of EMIT ${ }^{\circledR}$ and RIA high volume test procedure for THC metabolites in urine utilizing $\mathrm{CG} / \mathrm{MS}$ confirmation. J.Anal.Toxicol., Niles, v.10, p.178-180, 1986.

002.AGURELL,S., HALLDIN,M., LINDGREN,J., OHLSSON,A., WIDMAN,M., GILLESPIE,H., HOLLISTER,L. Pharmacokinetcs and metabolism of $\Delta^{1}$-tetrahydrocannabinol and other cannabinoids with emphasis on man. Pharmacol.Rev., Baltimore, v.38, n.1,p.21-43, 1986.

003.ALBURGES, M.E., PEAT,M.A. Profiles of $\Delta^{9}$-tetrahydrocannabinol metabolites in urine of Marijuana users: preliminary observations by high performance liquid chromatography-radioimmunoassay. J. Forensic Sci., Philadelphia, v.31, n.2, p.695-706, 1986.

* De acordo com a norma NBR 6023/89 preconizada pela Associação Brasileira de Normas Técnicas (ABNT). As abreviaturas e local de publicação dos títulos dos periódicos seguem o Chemical Abstracts Service Source Index (CASSI), 1990. 
004.ALMEIDA FILHO,N., SANTANA,V.S., PINTO,I.M., CARVALHO NETO,J.A. Is there an epidemic of drug misuse in Brazil? A review of the epidemiologic evidence (1977-1988). Int. J. Addict., New York, v.26, n.3, p.355-369, 1991.

005.ANDERSEN,J.M., NIELSEN,E., SCHOU,J., STEENTOFT,A., WORM,K. A specific method for the demostration of cannabis intake by TLC of urine. Acta Pharmacol. Toxicol., Copenhagen, v.29, p.111-112, 1971.

006.BAKER,T.S., HARRY,J.V., RUSSELL,J.W., MYERS,R.L. Rapid method for the CG/MS confirmation of 11-nor-9-carboxy- $\Delta^{9}$-tatrahydrocannabinol in urine. J.Anal.Toxicol., Niles, v.8, p.255-259, 1984.

007.BARBOSA,M.T.S., COTRIM,B.C., SILVA FILHO,A.R., CARLINI,E.A. Levantamento nacional sobre 0 uso de drogas psicotrópicas na população estudantil. Ciênc. Cult., São Paulo, v.40, n.7 supl., p. 987, 1988,

008.BASELT,R.C. Urine drug screening by immunoassay: interpretation of results. Adv. Anal. Toxicol. Foster City, v.1, p.81-123, 1984.

009.BECKER,R.S. Theory and interpretation of fluorescence and phosphorescence. New York: Wiley Interscience, 1969. p.76-90.

010.BELL,R., TAYLOR,E.H., ACKERIMAN,B., PAPPAS,A.A. Interpretation of urine quantitative 11-nor- $\Delta^{9}$-tetrahydrocannabinol-9-carboxylic acid to determine abstinence from Marijuana smoking. Clin.Toxicol., New York, v. 27, n. $1 \& 2$, p. $109-115,1989$.

011.BERGMAN, R.A., LUKASZEWSKI, T., WANG, S.Y.S. The detection of tetrahydrocannabinol in blood: a comparative study. J.Anal.Toxicol. Niles, v.5, p.85-89, 1981.

012.BLACK,D.L., GOLDBERGER,B.A., ISENSCHMID,D.S., WHITE,S.M., CAPLAN,Y.H. Urine cannabinoid analysis: an integrated multi-method approach. J.Anal.Toxicol., Niles, v.8, p.224-227, 1984. 
013.BOGUSZ,M. Concerning blood cannabinoids and the effect of residual THCCOOH on calculated exposure time. J.Anal.Toxicol. , Niles, v.17, p.313, 1993.

014.BRASIL.Ministério da Justiça.Secretaria da Polícia Federal. Dados de apreensões de entorpecentes efetuadas em todo Brasil. 1994.

015.BRONNER,W.E. , XU,A.S. Gas chromatographic-mass spectrometric methods of analysis for detection of 11-nor- $\Delta{ }^{9}$-tetrahydrocannabinol- 9-carboxylic acid in biological matrices. J.Chromatogr., Amsterdam, v.580, p.63-75, 1992.

016.BRONNER, W.E., NYMAN, P., MINDEN, D. Detectability of phencyclidine and 11-nor- $\Delta^{9}$-tetrahydrocannabinol-9-carboxylic acid in adulterated urine by radioimmunoassay and fluorescence polarization immunoassay. J.Anal.Toxicol., Niles, v. 14, p.368-371, 1990.

017.BUDGETT,W.T., LEVINE,B., XU,A., SMITH,M.L. Comparison of Abbott fluorescence polarization immunoassay (FPIA) and Roche radioimmunoassay for the analyses of cannabinoids in urine specimens. J.Forensic Sci., Philadelphia, V.37, n.2, p.632-635, 1992.

018.CARLSON,B.R., EDWARDS,W.H. Human values and marijuana use. Int.J.Addict., New York, v.25, n.12, p.1393-1401, 1990.

019.CATLIM,D., COWAN,D., DONIKE,M., FRAISSE,D., OFTEBRO,H., RENDIC,S. Testing urine for drugs. Clin.Chim.Acta, Amsterdam, v.207, p.513-526, 1992.

020.CENTRO BRASILEIRO DE INFORMAÇÕES SOBRE DROGAS PSICOTRÓPICAS. Catálogo das publicações cientificas brasileiras sobre o abuso de drogas psicotrópicas. São Paulo, 1991. 153 p.

021.CHIANG,C.N. , BARNETT,G. Marijuana pharmacokinetics and pharmacodynamics. In: REDDA,K.K., WALKER,C.A., BARNETT,G., eds. Cocaine. marijuana, designer drugs: chemistry, pharmacology, and behavior. Boston: CRC Press, 1989. p.113-125. 
022.CHRISTOPHERSEN,A.S. Tetrahydrocannabinol stability in whole blood: plastic versus glass containers. J.Anal. Toxicol., Niles, v.10, p.129-131, 1986.

023.ClOUeTTE, R., JACOB, M., KOTEEL, P., SPAIN, M. Confirmatión of 11 -nor- $\Delta{ }^{9}$-tetrahydrocannabinol in urine as its t-butyldimethylsilyl derivative using CG/MS. J.Anal.Toxicol., Niles, v.17, p.1-4, 1993.

024.CODY,J.T. SCHWARZHOFF,R.H. Impact of adulterants on RIA analysis of urine for drugs of abuse. J.Anal.Toxicol., Niles, v.13, p.277-284, 1989.

025.CONE,E.J., HUESTIS,M.A. Relating blood concentrations of tetrahydrocannabinol and metabolites to pharmacologic effects and time of marijuana usage. Ther.Drug Monit., New York, v.15, n.6, p.527-532, 1993.

026.CONE, E.J., JOHNSON, R.E., DARWIN, W.D., YOUSEFNEJAD, D., MELL, L.D., PAUL,B.D., MITCHELL,J. Passive inhalation of marijuana smoke: urinalysis and room air levels of $\Delta^{9}$-tetrahydrocannabinol. J.Anal.Toxicol., Niles, v.11, p.89-96, 1987.

027.COTRIM,B.C., CARLINI,E.A. The use of solvents and others drugs among children and adolescents from a low socioeconomic background: a study in São Paulo, Brazil. Int. J.Addict., New York, v.23, n.11, p.1145-1156, 1988.

028.COTRIM, B.C., SILVA FILHO, A.R., BARBOSA, M.T.S. , CARLINI, E.A. Levantamento nacional sobre internações por dependentes de drogas psicotrópicas. Ciênc.Cult., São Paulo, v.40, n.7 supl., p. 982-983, 1988.

029.COTRIM, B.C. Dados sobre o consumo de drogas por adolescentes no Brasil. In: SIMPÓSIO DE INTEGRAÇÃO ENTRE A CLÍNICA E A PSIQUIATRIA. 4. São Paulo, Biogalênica, 1987. p.85-91.

030.DANDLIKER,W.B., FEIGEN,G.A. Quantification of the antigen-antibody reaction by the polarization of fluorescence. Biochem.Biophys.Res.Commun., New York, v.5, n.4, p.299-304, 1961. 
031.DEGEL,F., BROCKHAUS,W., JALALIAN,M. Drogenscreening im Urin mit dem VITALAB-ECLAIR® Fluoreszenz-polarisations-Immuno-assays. Klin.Lab., Darmstadt,v.39, p.381-387, 1993.

032.DEMBO, R., WILLIAMS, L., LA VOIE, L., SCHMEIDLER, J., KERN, J., GETREU, A., BERRY, E., GENUNG, L., WISH, E.D. A longitudinal study of the relationship among alcohol use, marijuana / hashish use, cocaine use, and emotional, psychological functioning problems in a cohort of high-risk youths. Int.J.Addict., New York, v.25, n.11, p.1341-1382, 1990.

033.DEMBO, R., WILLIAMS, L., WISH, E.D., BERRY, E., GETREU, A., WASHBURN, M., SCHMEIDLER,J. Examination of relationships among drug use, emotional /psychological problems, and crime among youths entering a juvenile detention center. Int.J.Addict., New York, v.25, n.11, 1301-1340, 1990.

034.DEWEY,W.L. Cannabinoid pharmacology. Pharmacol. Rev., Baltimore, v.38, n.2, p.151-178, 1986.

035.DIXIT,V., DIXIT,V.M. Solid-phase extraction of 11-nor- $\Delta^{9}$-tetrahydrocannabinol-9-carboxylic acid from human urine with gas chromatographic - mass spectrometric confirmation. J.Chromatogr., Amsterdam, v.567, p.81-91, 1991.

036.EDWARDS, C., FYFE, M.J., LIU, R.H., WALIA, A.S. Evaluation of common urine specimen adulteration indicators. J.Anal.Toxicol., Niles, v.17, p. 251-252, 1993.

037.ELLIS Jr,G.M., MANN,M.A., JUDSON,B.A., SCHRAMM,N.T., TASHCHIAN,A. Excretion patterns of cannabinoid metabolites after last use in a group of chronic users. Clin.Pharmacol.Ther., St.Louis, v.38, n.5, p.572-578, 1985.

0.38.ELSOHLY, M.A., LITTLE Jr, T.L., STANFORD, D.F. Hexadeutero - $11-$ nor $-\Delta^{9}$ -tetrahydrocannabinol-9-carboxylic acid: a superior internal standard for the CG/MS analysis of $\Delta^{9}$-THC acid metabolite in biological specimens. J.Anal.Toxicol., Niles, v.16, p.188-191, 1992. 
039.ELSOHLY, M.A., JONES, A.B., ELSOHLY, H.N. Cross - reactivity of selected compounds in the Abbott Tdx® cannabinoid assay. J.Anal.Toxicol., Niles, v.14, p. 277-279, 1990.

040.ELSOHLY,M.A., ELSOHLY,H.N. Marijuana: analysis and detection of use through urinalysis. In : REDDA, K. K., WALKER, C. A., BARNETT, G., eds. Cocaine, marijuana,designer drugs: chemistry, pharmacology, and behavior. Boston: CRC Press, 1989. p.145-161.

041.FAIRBAIRN,J.W., LIEBMANN,J.A., ROWAN,M.G. The stability of cannabis and its preparations on storage. Pharm.Pharmacol., London, v.28, p.1-7, 1976.

042.FERRARA,S.D., TEDESCHI,L., FRISON,G., CASTAGNA,F. Solid - phase extraction and HPLC-UV confirmation of drugs of abuse in urine. J.Anal.Toxicol., Niles, v.16, p.217-222, 1992.

043.FINKLE,B.S., BLACK,D., BLANKE,R.V., BUTLER,T.J., JONES,G.R., SAMPLE,R.H.B. Analysis for commonly abused drugs in urine at selected threshold ("cutoff") concentrations. Clin.Chem., Winston-Salem, v.37, n.4, p. 586-587, 1991.

044.FOLTZ,R.L., SUNSHINE,I. Comparison of a TLC method with EMIT® and CG/MS for detection of cannabinoids in urine. J.Anal.Toxicol., Niles, v.14, p.375-378, 1990.

045.FOLTZ, R.L. Analysis of cannabinoids in physiological specimens by gas chromatography / mass spectrometry. Adv. Anal. Toxicol., Foster City, p.125$157,1984$.

046.FRASER, A.D., MEATHERALL, R. Lack of interference by Nabilone in the $E M I T{ }^{\circledR}$ d.a.u. cannabinoid assay, Abbott $T D x^{\circledR}$ cannabinoid assay, and a sensitive TLC assay for $\Delta^{9}$-THC-carboxylic acid. J.Anal.Toxicol., Niles, v. 13 , p.240, 1989.

047.FREDERICK,D.L., GREEN,J. Comparison of six cannabinoid metabolite assays. J.Anal.Toxicol., Niles, v.9, p.116-120, 1985. 
048.FRINGS, C.S., WHITE, R.M., BATTAGLIA, D.J. Status of drugs-of-abuse testing in urine:an AACC study. Clin.Chem., Winston-Salem, v.33, n.9, p.1683$1686,1987$.

049.FRINGS, C.S., WHITE, R.M., BATTAGLIA, D.J. Status of drugs-of-abuse testing in urine under blind conditions: an AACC study. Clin.Chem., WinstonSalem, v.33, n.5, p.891-894, 1989.

050.GARRIOT, J.C., Di MAIO, V.J.M., RODRIGUEZ, R.G. Detection of cannabinoids in homicide victims and motor vehicle fatalities. J.Forensic Sci., Philadelphia, v.31, n.4, p.1274-1282, 1986.

051.GAWIN,F.H. Laboratory assessments in treatments of substance abuse: utilization and effects on treatment design. Clin.Chem., Winston-Salem, v.33, n.11B, p.95B-100B, 1987.

052.GEROSTAMOULOS,J., DRUMMER, O.H. Incidence of psychoactive cannabinoids in drivers killed in motor vehicle accidents. J.Forensic.Sci., Philadelphia, v.38, n.3, p.649-656, 1993.

053.GIKOVATE,F. Drogas: opção de perdedor. São Paulo: Moderna, 1992. 85 p.

054.GOSLING,J.P. A decade of development in immunoassay methodology. Clin.Chem., Winston-Salem, v.36, n.8, p.1408-1427, 1990.

055.GUBITZ, G., WINTERSTEIGER, R. Identification of drugs of abuse by highperformance thin-layer chromatography. J.Anal.Toxicol., Niles, v.4, p.141144,1980 .

056.GUTIERREZ,M.C., GOMES-HANS,A., PEREZ-BENDITO,D.Immunoassay methods based on fluorescence polarization. Talanta, London, v.36, n.12, p.11871201,1989 .

057.GURKIN,M. How do HPTLC and S-HPTLC compare with TLC? J.Chromatogr.Sci., Niles, v.26, p.596, 1988. 
058. HARVEY,D.J., PATON,W.D.M. Metabolism of the cannabinoids. Rev. Biochem. Toxicol. , New York, p.221-264, 1984.

059.HARVEY,D.J. Cannbinoids analysis. In: CURRY, A.S., ed. Analytical methods in human toxicology. London: Macmillan Press, 1984, p.257-297.

060.HOLLISTER,L.E. Health aspects of cannabis. Pharmacol.Rev., Baltimore, v.38, n. 1, p.1-20, 1986.

061.HUESTIS,M.A., HENNINGFIELD,J.E., CONE,E.J. Blood cannabinoids. M. Models for the prediction of time of marijuana exposure from plasma concentrations of $\Delta^{9}$-tetrahydrocannabinol (THC) and 11-nor-9-carboxy- $\Delta^{9}$ tetrahydrocannabinol (THCCOOH). J.Anal.Toxicol., Niles, v.16, p.283-290, 1992.

062.HUESTIS,M.A., HENNINGFIELD,J.E., CONE,E.J. Blood cannabinoids. I. Absorption of THC and formation of 11-OH-THC and $\mathrm{THCCOOH}$ during and after smoking marijuana. J.Anal.Toxicol., Niles, v.16, p.276-282, 1992.

063.HUGHES,R.B., KESSLER,R.R. Increased safety and specificity in the thin-layer chromatographic identification of marijuana. J.Forensic Sci., Philadelphia, v.24, n.3, p.842-846, 1979.

064.ISENSCHMID,D.S., CAPLAN, Y.H. A method for the determination of 11-nor- $\Delta^{9}$ tetrahydrocannabinol-9-carboxylic acid in urine using high performance liquid chromatography with electrochemical detection. J.Anal.Toxicol., Niles, v.10, p. $170-174,1986$

065.ISENSCHMID,D.S., CAPLAN,Y.H. Incidence of cannabinoids in medical examiner urine specimens. J.Foresinc.Sci., Philadelphia, v.33, n.6, p.1421-1431, 1988.

066.JAFFE,J.H. Drug addiction and drug abuse. In: GILMAN, A.G., GOODMAN, L.S., RALL, T.W., MURAD, F., eds. The pharmacological basis of therapeutics . 7.ed. New York: Macmillan, 1985. p.558-561.

067.JOERN,W.A. Detection of past and recurrent marijuana use by a modofied CG/MS procedure. J.Anal.Toxicol., Niles, v.11, p.49-52, 1987. 
068.JOERN,W.A. CG/MS assay of the marijuana carboxy metabolite: urine interference with the dimethyl derivative. J.Anal.Toxicol., Niles, v.16, p.207, 1992.

069.JOERN,W.A. Surface adsorption of the urinary marijuana carboxy matabolite: the problem and a partial solution. J.Anal.Toxicol., Niles, v.16, p.401, 1992.

070.JOHANSSON,E., AGURELL,S., HOLLISTER,L.E., HALLDIN,M.M. Prolonged apparent half-life of $\Delta^{1}$-tetrahydrocannabinol in plama of chronic marijuana users. J.Pharm.Pharmacol., London, v.40, p.374-375, 1988.

071.JOHANSSON, E., GILLESPIE, H.K., HALLDIN, M.M. Human urinary excretion profile after smoking and oral administration of $\left[{ }^{14} \mathrm{C}\right]-\Delta^{1}$ - tetrahydrocannabinol. J.Anal.Toxicol., Niles, v.14, p.176-180, 1990.

072.JOHNSON, J.R., JENNISON, T.A., PEAT, M.A., FOLTZ, R.L. Stability of $\Delta^{9}$-THC, 11-hidroxy-THC, and 11-nor-carboxy-THC in blood and plasma. J.Anal.Toxicol., Niles, v.8, p.202-204, 1984.

073.JOLLEY,M.E. Fluorescence polarization immunoassay for the determination of therapeutic drug levels in human plasma. J.Anal.Toxicol., Niles, v.5, p.236$240,1981$.

074.JONES,A.B., ELSOHLY,H.N., ELSOHLY,M.A. Analysis of the major metabolite of $\Delta^{9}$-tetrahydrocannabinol in urine. $V$. Cross-reactivity of selected compounds in a radioimmunoassay. J.Anal.Toxicol., Niles, v.8, p.252-254, 1984.

075.JONES,R.T. Drug of abuse profile: cannabis. Clin.Chem., Winston-Salem, v.33, n. 11B, p.72B-81B, 1987.

076.KÄFERSTEIN,H., STICHT,G. Erfahrungen mit einen neuen FPIA-system beim nachweis von Drogen in Urin. Labor-Medizin, Darmstadt, v.16, p.60-64, 1993.

077.KAISTHA, K.K., TADRUS, R. Semi-quantitative thin-layer mass-screening detection of $11-$ nor $-\Delta^{9}$ - tetrahydrocannabinol-9-carboxylic acid in human urine. J.Chromatogr., Amsterdam, v.237, p.528-533, 1982. 
078.KANTER,S.L., HOLLISTER,L.E., MUSUMECI,M. Marijuana metabolites in urine of man. X.Identification of marijuana use by detection of $\Delta^{9}$-tetrahydrocannabinol-11-oic acid using thin-layer chromatography. J.Chromatogr., Amsterdam, v.234, p.201-208, 1982.

079.KANTER, S.L., HOLLISTER, L.E., ZAMORA, J.U. Marijuana metabolites in urine of man. XI. Detection of unconjugated nd conjugated $\Delta^{9}$ tetrahydrocannabinol- 11-oic acid by thin-layer chromatography. J.Chromatogr., Amsterdam, v.235, p.507-512, 1982.

080.KANTER,S.L., HOLLISTER,L.E., WILLIAMS,M. Extraction of glucuronide metabolites of $\Delta^{9}$-tetrahydrocannabinol by diethyl ether. J.Chromatogr., Amsterdam, v.234, p.255-260, 1982.

081.KANTER, S.L., HOLLISTER, L.E. Marijuana metabolites in urine of man. IX. Identification of $\Delta^{9}$ - tetrahydrocannabinol - 11- oic acid by thin-layer chromatography. J.Chromatogr., Amsterdam, v.151, p.225-227, 1978.

082.KARLSSON,L., ROOS,C. Combination of liquid chromatography with ultraviolet detection and gas chromatography with electron-capture detection for the determination of $\Delta^{9}$-tetrahydrocannabinol-11-oic acid in urine. J.Chromatogr., Amsterdam, v.306, p.183-189, 1984.

083.KARLSSON,L., STROM,M. Laboratory evaluation of the TDX® assay for detection of cannabinoids in urine from prison inmates. J.Anal.Toxicol., Niles, v.12, p.319-321, 1988.

084.KELLY, P., JONES, R.T. Metabolism of tetrahydrocannabinol in frequent and infrequent marijuana users. J.Anal.Toxicol., Niles, v.16, p.228-235, 1992.

085.KELLY,T.H., FOLTIN,R.W., EMURIAN,C.S., FISCHMAN,M.W. Performancebased testing for drugs of abuse: dose and time profiles of marijuana, amphetamine, alcohol and diazepam. J.Anal.Toxicol., Niles, v.17, p.264-272, 1993. 
086.KING, D.L., GABOR, M.J., MARTEL, P.A., O'DONNELL, C.M. A rapid sample-preparation technique for thin-layer chromatographic analysis for 11-nor- $\Delta^{9}$-tetrahydrocannabinol-9-carboxylic acid in human urine. Clin.Chem., Winston-Salem, v.35, n.1, p.163-166, 1989.

087.KING,L.A., MILLER,J.N. Fluorescence analysis. In: CURRY,A.S., ed. Analytical methods in human toxicology. London: Macmillan, 1986. p.71-112.

088. KINGERY,P.M., PRUITT,B.E., HURLEY,R.S. Violence and illegal drug use among adolescents: evidence from the U.S. National Adolescent Student Health Survey. Int.J.Addict., New York, v.27, n. 12, p. 1445-1464, 1992.

089. KINTZ, P., LUDES, B., MANGIN, P. Detection of drugs in human hair using Abbott $A d x^{\circledR}$, with confirmation by gas chromatography / mass spectrometry (CG/MS). J.Forensic Sci., Philadelphia, v.37, n.1, p.328-331, 1992.

090.KOGAN, M.J., NEWMAN, E., WILLSON, N.J. Detection of marijuana metabolite 11-nor- $\Delta^{9}$-tetrahydrocannabinol-9-carboxylic acid in human urine by bonded-phase adsorption and thin-layer chromatography. J.Chromatogr., Amsterdam, v.306, p.441-443, 1984.

091.KUHNS,J.B., HEIDE,K.M., SILVERMAN,I. Substance use $/$ misuse among female prostitutes and female arrestees. Int.J.Addict., New York, v.27, n.11, p.1283-1292, 1992.

092.LAFOLIE, P., BECK, O., BLENNOW, G., BORÉUS, L., BORG, S., ELWIN, C.E., KARLSSON,L., ODELIUS,G., HJEMDAHL,P. Importance of creatinine analyses of urine when screening for abused drugs. Clin.Chem., WinstonSalem, v.37, n.11, p.1927-1931, 1991.

093.LAW,B., MASON,P.A., MOFFAT,A.C. Confirmation of cannabis use by the analysis of $\Delta^{9}$-tetrahydrocannabinol metabolites in blood and urine by combined HPLC and RIA. J.Anal.Toxicol., Niles, v.8, p.19-22, 1984.

094.LAW,B., MASON,P.A., MOFFAT,A.C., KING,L.J., MARKS,V. Passive inhalation of cannabis smoke. J.Pharm.Pharmacol., London, v.36, p.578-581, 1984. 
095.MANNO,J.E. Interpretation of urinalysis results. NIDA - Res.Monogr., Rockville, v.73, p.54-61, 1986.

096.MAUNDER, M. J. DE F. Preservation of cannabis thin - layer chromatograms J.Chromatogr., Amsterdam, v.100, p.196-199, 1974.

097.MCCURDY,H.H., LEWELLEN,L.J., CALLAHAN,L.S., CHILDS,P.S. Evaluation of the Ion Trap Detector for the detection of 11-nor- $\Delta^{9}-$ THC-9-carboxylic acid in urine after extraction by bonded - phase adsorption. J.Anal.Toxicol., Niles, v.10, p.175-177, 1986.

098.MEATHERALL, R.C., GARRIOTT, J.C. A sensitive thin - layer chromatographic procedure for the detection of urinary 11-nor- $\Delta^{9}$ tetrahydrocannabinol-9- -carboxylic acid. J.Anal.Toxicol., Niles, v.12, p.136140, 1988.

099.MEATHERALL,R.C. , WARREN,R.J. High urinary cannabinoids from a hashish body packer. J.Anal.Toxicol., Niles, v.17, p.439-440, 1993.

100.MIKKELSEN,S.L., ASH,K.O. Adulterants causing false negatives in illicit drug testing. Clin.Chem., Winstom-Salem, v.34, n.11, p.2333-2336, 1988.

101.MITCHELL,J.D., PERRIGO,B.J., MASON-DANIEL,V.A. Falsely negative urine drug assay results due to filtration. Clin.Chem., Winston-Salem, v.38, n.2, p.2556-2557, 1992.

102.MOODY, D.E., MONTI, K.M., CROUCH, D.J. Analysis of forensic specimens for cannabinoids. II. Relationship between blood $\Delta^{9}$-tetrahydrocannabinol and blood and urine $11-$ nor $-\Delta^{9}$ - tetrahydrocannabinol - 9 - carboxylic acid concentrations. J.Anal.Toxicol., Niles, v.16, p.302-306, 1992.

103.MOODY,D.E., RITTENHOUSE,L.F., MONTI,K.M. Analysis of forensic specimens for cannabinoids. I. Comparison of RIA and CG/MS analysis of blood. J.Anal.Toxicol., Niles, v.16, p.297-301, 1992.

104.MULÉ,S.J., GROSS,S.J. Significance of urine assay sensitivity in marijuana detection. Clin.Chem., Winston-Salem, v.33, n.4, p.613, 1987. 
105.MULÉ, S.J., CASELLA, G.A. Confirmation of marijuana, cocaine, morphine, codeine, amphetamine, methamphetamine, phencyclidine by CG/MS in urine following immunoassay screening. J.Anal.Toxicol., Niles, v.12, p.102-107, 1988.

106.MULÉ,S.J., LOMAX,P., GROSS,S.J. Active an realistic passive marijuana exposure tested by three immunoassays and CG/MS in urine. J.Anal.Toxicol., Niles, v.12, p.113-116, 1988.

107.NAKAMURA, G.R., STALL, W.J., FOLEN, V.A., MASTERS, R.G. Thin layer chromatographic-mass spectrometric identification of $11-$ nor $-\Delta^{9}$ -tetrahydrocannabinol - 9 - carboxylic acid. J.Chromatogr., Amsterdam, v.264, p.336-338, 1983.

108.NEEDLEMAN,S.B., GOODIN,K., SEVERINO,W. Liquid-liquid extraction systems for THCCOOH and benzoylecgonine. J.Anal.Toxicol., Niles, v.15, p.179-181, 1991.

109.ORGANIZAÇÃO MUNDIAL DE SAÚDE. Métodos recomendados para el ensavo de la cannabis. Viena, 1987. 38p.

110.PARRY,R.C., NOLAN,L., SHIREY,R.E., WACHOB,G.D., GISCH,D.J. Pretreatment of urine samples for the analysis of 11-nor- $\Delta^{9}$-tetrahydrocannabinol-9carboxylic acid using solid-phase extraction. J.Anal.Toxicol. , Niles, v.14, p.39$44,1990$.

111.PAUL, B.D., McKINLEY, R.M., WALSH Jr, J.K., JAMIR, T.S., PAST, M.R. Effect of freezing on the concentration of drugs of abuse in urine. J.Anal.Toxicol., Niles, v.17, p.378-380, 1993.

112.PEARSON, S.D., ASH, K.O., URRY, F.M. Mechanism of false - negative urine cannabinoid immunoassay screens by VISINETM eyedrops. Clin.Chem., Winston-Salem, v.35, n.4, p.636-638, 1989.

113.PEAT,M.A.,DEYMAN,M.E., JOHNSON,J.R. High performance liquid chromatography - immunoassay of $\Delta^{9}$ - tetrahydrocannabinol and its metabolites in urine. J.Forensic Sci., Philadelphia, v.29, n.1, p.110-119, 1984. 
114.PEAT,M.A. The analysis of $\Delta^{9}$-tetrahydrocannabinol and its metabolites by immunoassay. Adv.Anal.Toxicol., Foster City, v.1, p.59-79,1984.

115.PODKOWIK, B., KIPPENBERGER, D.J., SMITH, M.L. Interference in CG/MS confirmation of $\Delta^{9}$ - tetrahydrocannabinol - 9 - carboxylic acid by a secondary tetrahydrocannabinol metabolite. Clin.Chem., Winston-Salem, v. 37, n.7, p.1307-1308, 1991.

116.PORTMANN,A.J., DANDLIKER,W.B. Anti-fluresceina antibody of high affinity and restricted heterogeneity as caracterized by fluorescence polarization and quenching equilibrium techniques. Biochem. Biophys.Res.Commun., New York, v.43, n.1, p.207-212, 1971.

117.POPELKA,S.R., MILLER,D.M., HOLEN,J.T., KELSO,D.M. Fluorescence polarization immunoassay II. Analyser for rapid, precise, measurement of fluorescence polarization with use of disposable cuvettes. Clin.Chem., Winston-Salem, v.27, n.7, p.1198-1201, 1981.

118. REINHARDT,V.E.D. Aspectos da análise toxicológica forense para identificação de usuários de Cannabis. São Paulo, 1993. p. [Dissertação - mestrado Faculdade de Ciências Farmacêuticas da USP].

119.ROLLINS, D.E., JENNISON, T.A., JONES, G. Investigation of interference by nonsteroidal anti-inflamatory drugs in urine tests for abused drugs. Clin.Chem., Winston-Salem, v.36, n.4, p.602-606, 1990.

120.SÁ,L.M. Identificação de canabinoides em urina humana por cromatografia de gás e enzimaimunoensaio com finalidade forense. São Paulo, 1981. 80p. [ Tese - Livre Docência - Faculdade de Ciências Farmacêuticas da USP].

121.SCHRAMM, W., SMITH, R.H., CRAIG, P.A. Drugs of abuse in saliva: a review. J.Anal.Toxicol., Niles, v.16, p.1-9, 1992.

122.SCHWARTZ, R.H., WILLETTE, R.E., HAYDEN, G.F., BOGEMA, S., THORNE, M.M., HICKS, J. Urinary cannabinoids in monitoring abstinence in a drug abuse treatment program. Arch.Pathol.Lab.Med., Chicago, v.111, p.708-711, 1987. 
123.SCHWARZHOFF,R., CODY,J.T. The effects of adulterating agents on FPIA analysis of urine for drugs of abuse. J.Anal.Toxicol., Niles, v.17, p. 14-17, 1993. 124.SEGAL,B. Adolescent initiation into drug-taking behavior: comparisons over a 5-year interval. J.Int.Addict., New York, v.26, n.3, p.267-279, 1991.

125.SHAW, L.M., EDLING, J., MATTES, R. Ultrasensitive measurement of $\Delta^{9}$ - tetrahydrocannabinol with a high energy dynode detector and electroncapture negative chemical-ionization mass spectometry. Clin.Chem. Winston-Salem, v.37, n.12, p.2062-2068, 1991.

126.SMITH, R. N., VAUGHAN, C.G. The decomposition of acidic and neutral cannabinoids in organic solvents.J.Pharm.Pharmacol., London, v.23, p.190-195, 1971.

127.SMITH, T.E., KOOB, J., WIRTZ, T. Ecology of adolescents' marijuana abuse. Int.J.Addict., New York, v.20, n.9, p.1421-1428, 1985.

128.STAFFORD,P. Psychedelics encyclopedia. 3.ed. Berkeley: Ronin,1992. p.156-221.

129.STRASINGER, S.K. Urinalysis and body fluids: a self - instructional text. 2.ed. Philadelphia: F.A.Davis, 1989. p.1-45.

130.SUNSHINE,I. Preliminary tests for drugs of abuse. Clin.Chem., Winston-Salem, v.34, n.2, p.331-334, 1988.

131.SUTHEIMER,C.A., YARBOROUGH,R., HEPLER,B.R., SUNSHINE,I. Detection and confirmation of urinary cannabinoids. J.Anal.Toxicol., Niles, v.9, p.156-160, 1985.

132.TELLES,C. Aspectos legais e policiais das drogas no Brasil. Prevensão e repressão - capacitação profissional do policial. Arq. Policia Civil, São Paulo, V.36, p.41-61, 1981.

133.TURK,R.F., MANNO,J.E., JAIN,N.C., FORNEY,R.B. The identification, isolation, and preservation of $\Delta^{9}$-tetrahydrocannabinol. J.Pharm.Pharmacol., London, v.23, p.190-195, 1971. 
134.UDENFRIEND, S. Fluorescence assay in biology and medicine. New York: Academic Press, 1962. 443p.

135.VINSON,J.A., LOPATOFSKY,D.J. A semi-automated extraction and spotting system for drug analysis by TLC. I. Procedure for analysis of the major metabolite of $\Delta^{9}$-tetrahydrocannabinol in urine. J.Anal.Toxicol., Niles, v.9, p.6-9, 1985.

136.WALL,M.E., SADLER,B.M., BRINE,D., TAYLOR,H., PEREZ-REYES,M. Metabolism, disposition, and kinetics of $\Delta^{9}$-tetrahydrocannabinol in men and women. Clin.Pharmacol.Ther., ST.Louis, v.34, n.3, p.352-363, 1983.

137.WARNER,A. Interference of commom household chemicals in immunoassay methods for drugs of abuse. Clin.Chem., Winstom-Salem, v.35, n.4, p.648-651, 1989.

138.WARNER, M. Jumping to conclusions. Anal.Chem., Washington, v.59, n.7, p.521A-522A, 1987.

139.WATANABE, K., NARIMATSU, S., YAMAMOTO, I., YOSHIMURA, $H$. Oxygenation mechanism in conversion of aldehyde to carboxylic acid catalysed by a cytocrome P-450 isozyme. J.Biol.Chem., Baltimore, v.266, n.5, p.2709-2711, 1991.

140.WATANABE,K., YAMAMOTO,I., OGURI,K., YOSHIMURA,H. Microsomal oxygenase catalysed oxydation of 11 -hidroxy $-\Delta^{8}$-tetrahydrocannabinol to $11-0 x 0-\Delta^{8}$ - tetrahydrocannabinol. Biochem. Biophys. Res. Commun., New York, v.88, n.1, p.178-182, 1979.

141.WATSON,I.D. Analysis of commonly abused drugs in urine at selected threshold (cutoff) concentrations. Clin.Chem., Winstom-Salem, v.38, n.3, p.441, 1992.

142.WEINTRAUB, M. Sonhos e sombras: a realidade da maconha. São Paulo: Harper \& Row, 1983. 112p. 
143.WELLS, D.J., BARNHILL Jr,T.Comparative results with five cannabinoid immunoassay systems at the screening threshold of $100 \mathrm{ug} / \mathrm{L}$. Clin.Chem., Winstom-Salem, v.35, n.11, p.2241-2243, 1989.

144.WILLSON,N.J., KOGAN,M.J., PIERSON,D.J., NEWMAN,E. Confirmation of EMIT ${ }^{\circledR}$ cannabinoid assay results by bonded phase adsorption with thin layer chromatography. J.Toxicol.Clin.Toxicol., New York, v.20, n.5, p.465-473, 1983.

145.WINEK, C.L., ELZEIN, E.O., WAHBA, W.W., FELDMAN, J.A. Interference of herbal drinks with urinalysis for drugs of abuse. J.Anal.Toxicol., Niles, v.17, p.246-247, 1993.

146.WU,A.H.B., ONIGBINDE,T.A., WONG,S.S., JOHNSON,K.G. Evaluation of fullscanning GC / lon Trap MS analysis of NIDA drugs-of-abuse urine testing in urine. J.Anal.Toxicol., Niles, v.16, p.202-206, 1992.

147.XAVIER,G.M. Relatório sobre a situação brasileira do tráfico e consumo de drogas. Ministério da Justiça. Departamento de Polícia Federal. 1979. 8p.

148.YU,J., WILLIFORD,W.R. The age of alcohol onset and alcohol, cigarette, and marijuana use patterns: an analysis of drug use progression of young adults in New York state. Int.J.Addict., New York, v.27, n.11, p.1313-1323, 1992.

149.ZIMMERMAN,S., ZIMMERMAN, A.M. Genetic effects of marijuana. Int.J.Addict., New York, v.25, n.1A, p.19-33, 1990-1991. 


\section{ERRATA}

1. Página 60 - não houve inclusão da amostra $9 B$ na tabela 12 , cujo resultado é: não detectado (ND). À amostra 10 corresponde o resultado positivo (+).

2. Página 64 - não houve inclusão da amostra $9 \mathrm{~B}$ na tabela 15 , cujo resultado é negativo.

3. Página 71 - na tabela 20 , onde se lê canabinóides, leia-se $\mathrm{THCCOOH}$. 